Historic, Archive Document

Do not assume content reflects current scientific knowledge, policies, or practices. 



\section{High Class Seeds FOR 1911}

Burrell's Seleet Rust-Resistant Rocky Ford Cantaloupe If it is only one.

\section{V. Burrell Seed Grower Rocky Ford, Colorado.}




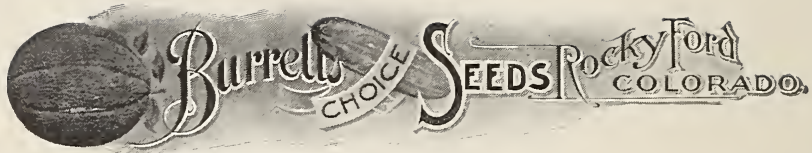

\section{Greeting to My Customers and Friends:}

Up to twelve years ago I followed market gardening, and following this business I found by careful selection, owing to the very favorable soil and climatic conditions existing here, the quality could be rapidly improved. I started growing and selling seeds at that time and my business has practically doubled each year since.

This year I had 400 acres of cantaloupes alone exclusively for seed.

I am pleased to number among my customers many of the most successful market growers of the United States.

This fall I have $\$ 20,000$ worth of seeds sold in advance which alone proves the dependence placed in them.

I want your orders. I will take good care to give you such seeds as will make it to your interest to become permanent customers.

I make a specialty of growing seeds for large planters under contract. Send me a list of the varieties you plant and quantity of each and I will make you growing price, crop 1911. If you prefer foreign grown seeds of any varieties, I have connections with the most careful growers of Denmark, Germany, France, Spain, and Canary Islands, and always considering quality first, I can make it to your interest to place your orders ahead.

I wish to call your attention to the following seeds for present orders and thanking you for the extensive favors of the past and soliciting your further patronage which shall have careful attention, I am, Yours truly,

D. V. BURRELL.

\section{IN D E X}

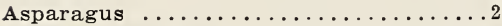

Asparagus Roots ..................

Beans .....................2-4

Beets .....................

Broccoli .......................

Brussels Sprouts ..............6

Cantaloupe and Muskmelon ........

............. 27-28-29-30-31-32

Chicory $\ldots \ldots \ldots \ldots \ldots \ldots \ldots \ldots \ldots$

Collards $\ldots \ldots \ldots \ldots \ldots \ldots \ldots \ldots$

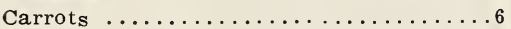

Cabbage ............ 7-8-9-10-11-12-13

Cauliflower ..................14-15

Celery ..................16

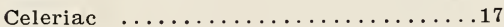

Cress ...........................

Curumber ................18-19-20

Citron ......................... 36

Corn, Sweet $\ldots \ldots \ldots \ldots \ldots \ldots \ldots 21-22$

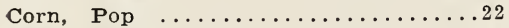

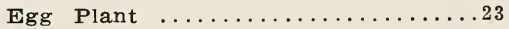

Endive $\ldots \ldots \ldots \ldots \ldots \ldots \ldots \ldots \ldots \ldots \ldots$

Flower Seeds .............57 to 65

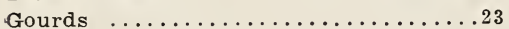

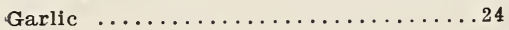

Herbs ..................... 4
Horse Radish Roots .............24

Kale or Borecole ...............24

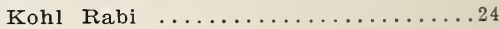

Leek .......................24

Lettuce $\ldots \ldots \ldots \ldots \ldots \ldots \ldots \ldots \ldots \ldots \ldots \ldots$ 25-26

Muskmelon and Cantaloupe

$27-28-29-30-31-32$

Mustard ......................

Onion $\ldots \ldots \ldots \ldots \ldots \ldots .37-38-39-40-41$

Onion Sets $\ldots \ldots \ldots \ldots \ldots \ldots \ldots \ldots 1$

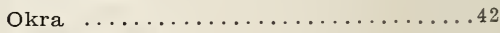

Pomegranate .................... 36

Pumpkin .................... 42

Parsley ......................43

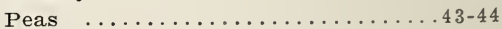

Parsnip ..................... 45

Pepper $\ldots \ldots \ldots \ldots \ldots \ldots \ldots \ldots \ldots \ldots+45-46$

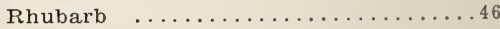

Radish ................. 46-47-48

Ruta-Baga $\ldots \ldots \ldots \ldots \ldots \ldots \ldots \ldots \ldots 6$

Salsify $\ldots \ldots \ldots \ldots \ldots \ldots \ldots \ldots \ldots$

Spinach .................... .48

Squash .................... 49-50

Tomato ............ 51-52-53-54-55

Turnip ....................... 56

Watermelon ............33-34-35-36 


\section{ORDER BLANK FOR HIGH GRADE TESTED SEEDS}

WRITE YOUR ADDRESS PLAINZY AND IN FULL in the blanks below : also beep yout orter separaco form other muler

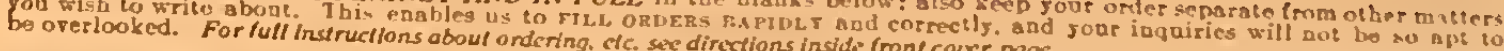

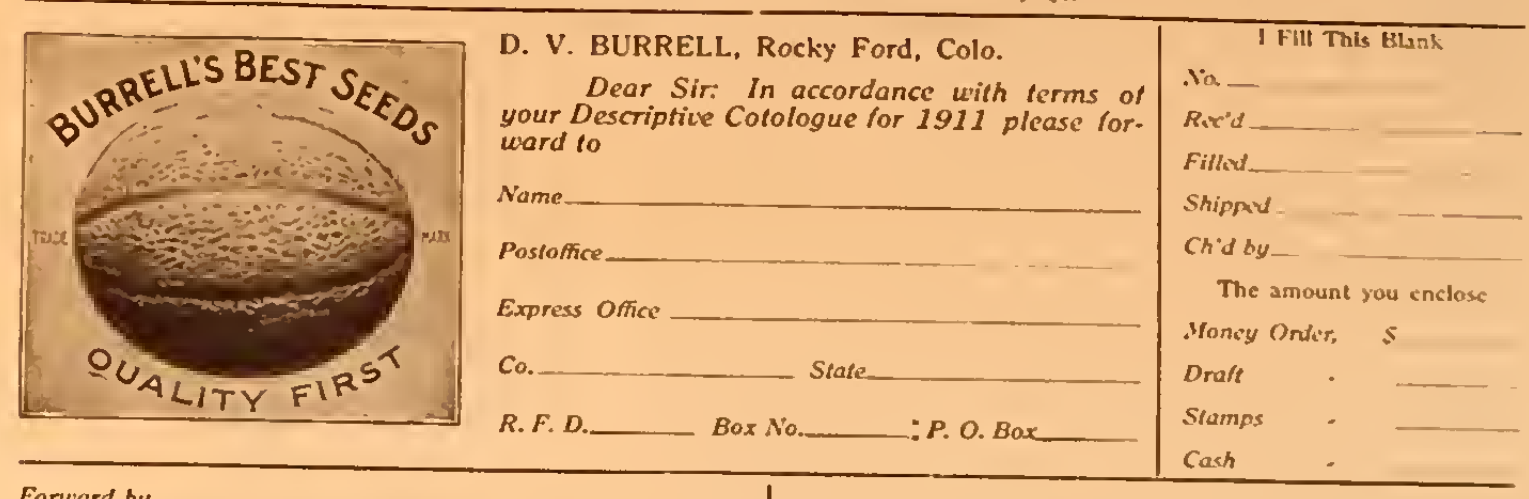

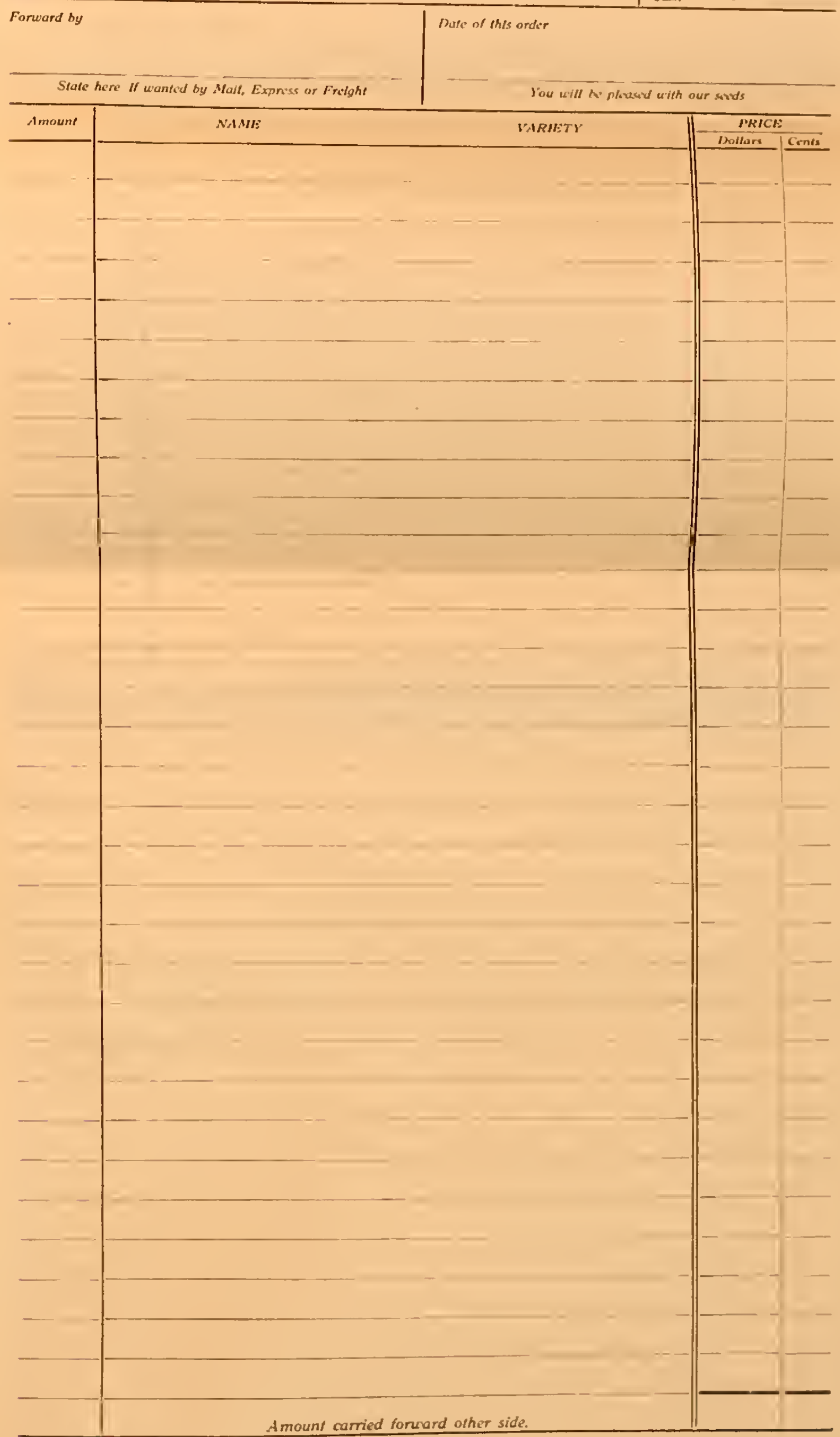




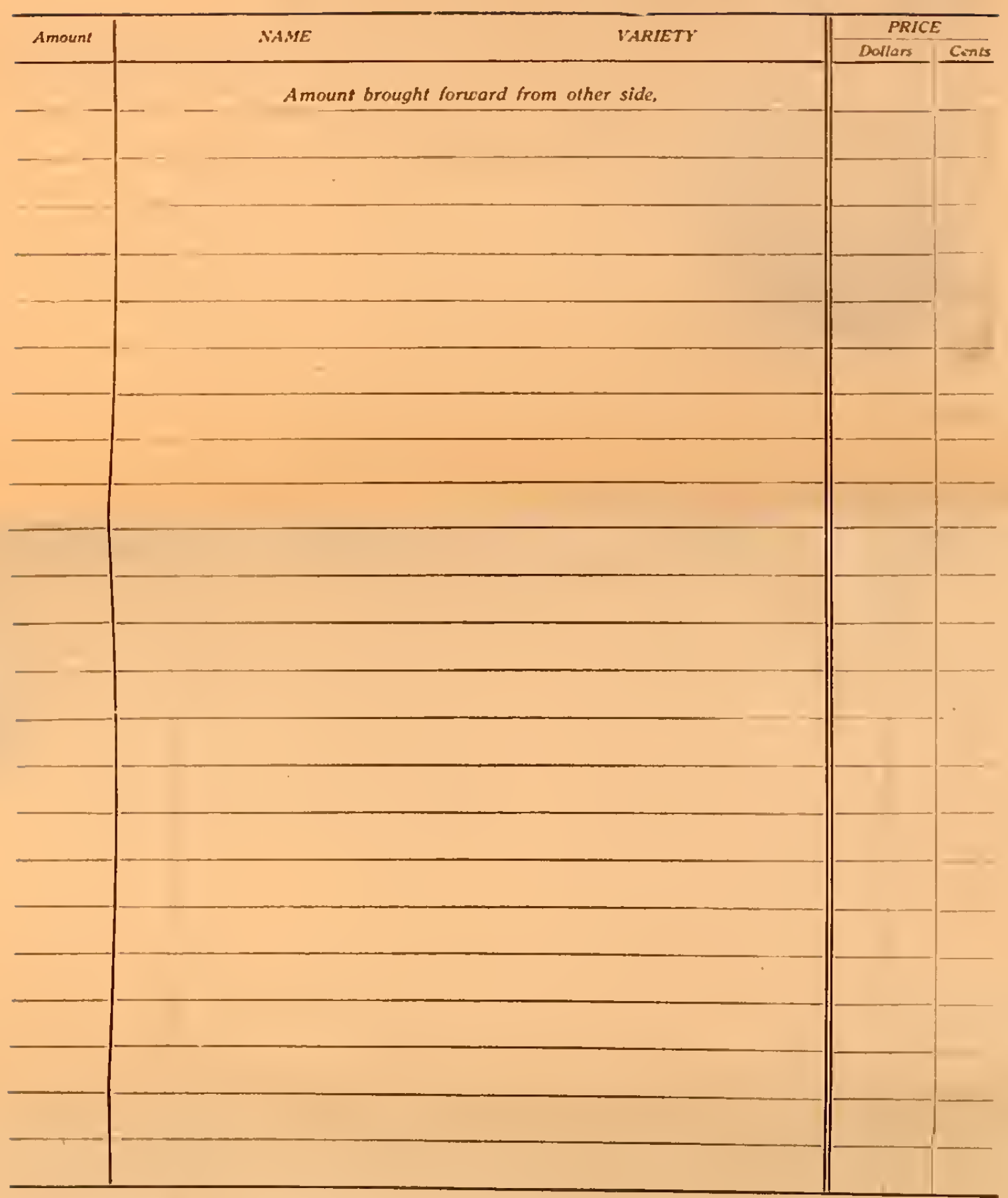

DO YOU GROW FOR MARKET OR HOME USE?

You will greatly oblige us if you will write here the names of some of your friends who grow a garden 


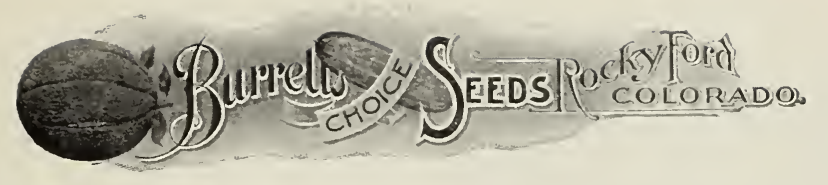

\section{Instructions to Purchasers}

Please follow these instructions carefully. If any mistakes occur or your order is delayed, let me hear from you promptly.

On small lots add $8 \mathrm{c}$ per pound if to go by mail.

MY TERMS ARE CASH WITH ORDER. Send Postoffice or Express Money Order, Postal Note, Bank Draft or Registered Letter. Small amounts may be in postage stamps.

C. O. D.-I will send goods C. O. D. by express where it is late in the season and you find it necessary to order by wire, but urge you to order early and avoid this expense of wiring and return charges.

HOW TO ORDER.-Always write your name, postoffice, state and express office plainly and if possible use the order sheet. Always carry out the price of each item.

Make all orders or checks payable to D. V. BURRELL.

SAFE ARRIVAL GUARANTEED.-I guarantee safe arrival of all seeds sent by mail or express, but request all to have their address plainly written. If the seeds are not received in a reasonable time, send an exact copy of the order and state kind of remittance and same will be given immediate attention.

HOW TO SHIP.-Always state how to ship heavy seeds if to go by Freight or Express.

GUARANTEE.-It is impractical to guarantee seeds, as under improper care the best of seeds will fail. Some may be sown too shallow or too deep, in too dry ground or too wet. Some hardy seeds will stand cool weather and grow when soil is too cold for others and will cause them to decay. Insects above or below the surface may attack and destroy them. For these reasons, D. V. Burrell, while exercising the greatest possible care to have all seeds true and reliable, gives no warranty, expressed or implied, and will not in any way be responsible for the crop.

\section{No Premiums}

I do not believe my customers approve of the giving of premiums. Somebody has to pay for them. My idea is to sell to those who buy to plant, looking forward to the growing of a good garden for home use or a PROFITABLE MARKET GARDEN, and to sell these seeds as low as I can afford, quality considered, but not to cut down the quality in order to meet prices made by others. In making up this catalog I have been guided entirely by the quality of the seeds I have to offer and the supply. I trust you will favor me with your orders, which will be carefully filled. 


\section{Burrell's Palmetto Asparagus}

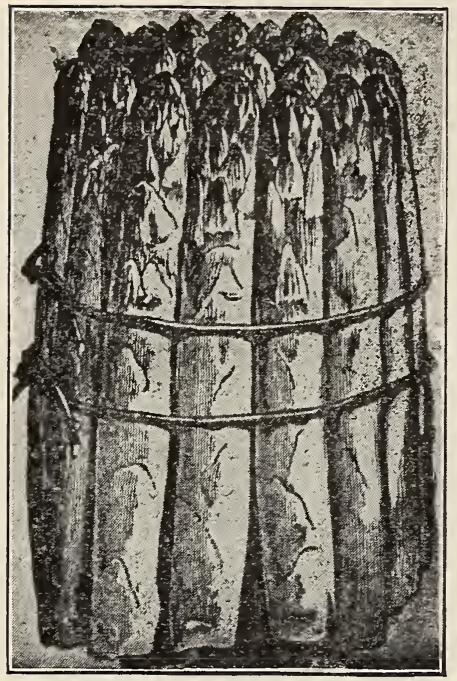

THE BEST SORT TO RESIST RUST.

My seed of this sort is saved from a special field and grown by one of the most successful Asparagus growers in the United States. It is large, very early and produces an abundant crop. In sections subject to Asparagus diseases, it has proven the most valuable sort. If you wish a large lot of seed to grow for market or a small lot to grow plants for your home garden, this is the variety you should have. An ounce of seed produces about 500 plants, a pound about 8,000 plants. The cost of seed is small compared with your results. Add $8 \mathrm{c}$ per pound if by mail.

Oz., 10c; 1/4 lb., 25c; lb., 50c; 100 lbs., 45c per lb.; 10 lbs. and up at $100-1 b$. rate.

Conover's Colossal. A standard variety; large, productive and of fine quality. Oz. $5 \mathrm{c} ; 1 / 4$ lb., 15c; lb., 45c; 5 lbs. and up, 40c per lb.

Columbian Mammoth White. A variety producing large white shoots. Oz., 5c; $1 / 4$ lb., 15c; lb., 45c; 5 lbs. and up, 40c per lb.

\section{Asparagus Roots}

Burrell's Palmetto. These charges are by freight or express, charges for transportation not prepaid. One year old roots: Doz., 15e; 100, 50c; 500, $\$ 2 ; 1000$, \$3.50; $10,000, \$ 2.75$ per thousand. Two year old roots: Doz., 25c; 100, 75c; 500, \$3; 1000 , \$5; 10,000, $\$ 4$ per thousand.

\section{Burrell's Spot Free Wardwell's Kidney Wax Beans}

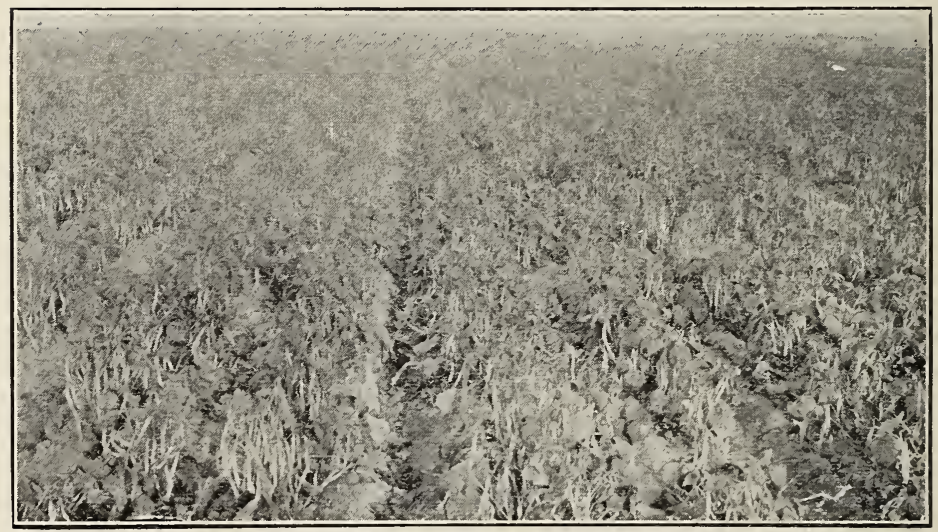

This is the finest sort for the market grower who raises wax beans to ship. My own growing of this seed has so far proven free of Pod Spot. The pods of Wardwell's Kidney Wax Beans are long, nearly straight, uniform in size, waxy yellow in color, entirely stringless, and are borne in abundance. They hold up well for shipment, are easily harvested and a profitable crop to grow.

Pt., 20c; qt., 35c; pk., $\$ 1.60$; bu., $\$ 6.00 ; 10$ bu. and up, $\$ 5.50$ per bu.

Many Southern growers state that they would rather pay this price and express charges on this seed than risk other seeds which are more liable to Pod Spot. Order early so they can be shipped by freight and save additional charges by express.

Michigan Grown Wardwell's Kidney Wax Beans. Pt., 15c; qt., 25c; pk., \$1.50; bu., $\$ 5.00 ; 10$ bu. and up, $\$ 4.50$ per bu.

On all beans add $8 \mathrm{c}$ per pint, $15 \mathrm{c}$ per quart, if by mail. 


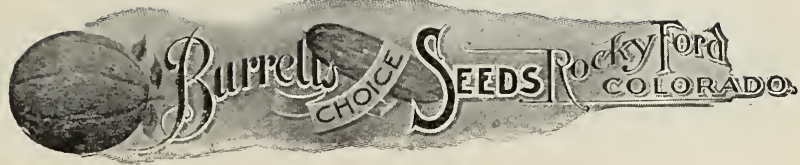

\section{Burrell's Pod Spot Free Davis White Kidney Wax Beans}

This bean is a great favorite with Southern growers.

The pods are long, straight, waxy yellow and stringless while young. The plants grow strong and yield an abundant crop.

I sell large quantities of this seed to Southern planters each year and have the most favorable reports on it.

Pt., 20c; qt., 35c; pk., $\$ 1.60$; bu., $\$ 6.00$; 10 bu. and up, $\$ 5.50$ per bu.

Michigan Grown Davis White Kidney Wax. Pt., 15e; qt., 25c; pk., \$1.50; bu., \$5.00; 10 bu. and up, $\$ 4.50$ per bu.

Keeney's Round Pod Kidney Wax. This valuable sort originated from Wardwell's Kidney Wax. The pods are round, fleshy, and waxy yellow; of excellent quality. Pt., 15c; qt., 25c; pk., \$1.50; bu., $\$ 5.50$.

German Black Wax Improved. A vigorous grower with ample foliage, sheltering the pods so that they are uniformly translucent and creamy yellow; very early, enormously productive and of fine quality. Pt., 15c; qt., 25c; pk., \$1.50; bu., $\$ 5.50$.

Golden Wax Improved. A handsome bean; rich golden pods without string, of tender melting quality; a superior bean for either private or market use. Pt.., 15c; qt., 25c; pk., \$1.50; bu., $\$ 5.50$.

Refugee Wax. Possesses the valuable characteristics of the green-podded Refugee; it is waxpodded and of great productiveness; practically everbearing. Pods handsome, round, transparent yellow, remaining tender long. A great drouth and rust-resister. Pt., 15c; qt., 25c; pk., $\$ 1.50$; bu., $\$ 5.00$.

\section{Beans, Bush Lima}

Henderson's Bush Lima. A true bush variety, 18 to 20 inches high, requiring no support; enormously productive and early. coming in weeks ahead of any other Lima and bearing continuously until frost, succeeding even in Northern states; the beans have the true Lima flavor, buttery, rich and tender. The surest cropper of all. Pt., 15c; qt., 25c; pk., \$1.65; bu., \$6.00.

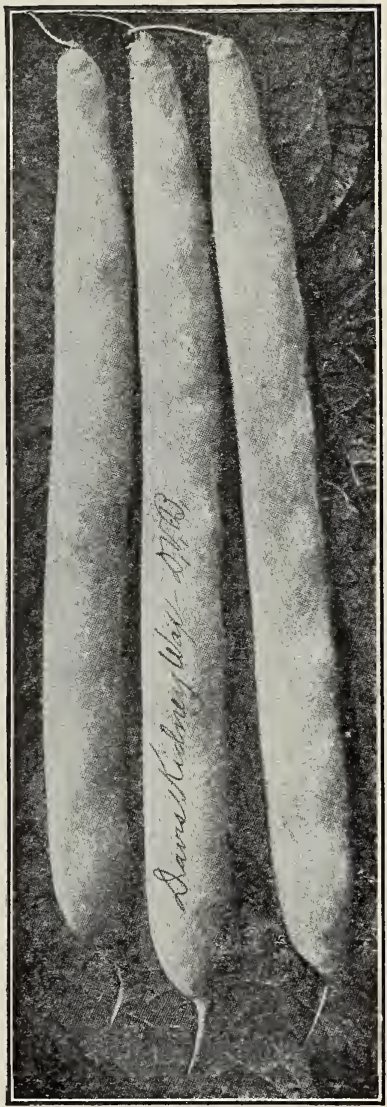

Burpee's Bush Lima. A bush form of the large White Lima, growing about 20 inches high; the pods and beans are nearly the same size as the latter. While not as early as Henderson's Bush Lima, its Jarge size commends it to many. Pt., 15c; qt., 25c; pk., \$1.65; bu., \$6.00.

Add $8 \mathrm{c}$ per pint, $15 \mathrm{c}$ per quart, if by mall. 


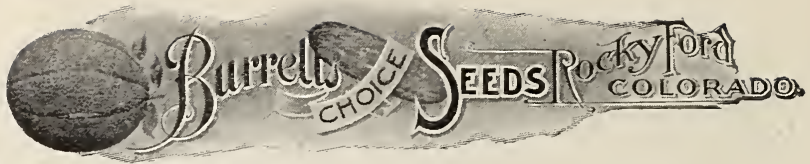

\section{Beans, Burpee's Stringless Green Pod}

This is the bean you want if you prefer a green pod snap bean. It is not equalled by any other green pod bean. It is quite hardy, extremely early and the tender stringless pods are of highest quality.

The pods are fleshy, being full and round before the beans begin to attain any size. They continue long in bearing when kept picked off and by planting two or three times during the season, the first planting as soon as danger from frost is past and then later plantings about four weeks apart, you can have fine snap beans from the last of June until frost in the autumn.

Price: Pt., 15c; qt., 25c; pk., \$1.50; bu., \$5.50; 10 bu. and up, $\$ 5.00$ per bu.

Refugee or 1,000 to 1 .-A popular medium to late variety, very productive; extensively grown for pickling; handsome, tender pods. Pt., 15c; qt., 25c; pk., $\$ 1.40$; bu., $\$ 5.00$; 10 bu. and up, $\$ 4.75$ per bu.

Red Valentine. The standard green-podded, dwarf snap bean, usually ready for plcking in 45 days; big yielder, fine quality. Pt., 15c; qt., 25c; pk., $\$ 1.40$; bu., $\$ 5.00$; 10 bu. and up, $\$ 4.75$ per bu.

Early Mohawk. Very early and largely grown South for Northern markets; will stand more cold than most sorts; 5 to 6 -inch pods. Pt., 10c; qt., 20c; pk., \$1.00; bu., \$3.75.

The Mexican Bean is grown extensively here and gets its name from the fact that it is more sought after by Mexicans than any other variety. The beans are medium size and speckled; a prolific yielder and an excellent field hean. This is the Mexican Chili Bean. Pt., 15c; qt., 25c; pk., $\$ 1.25 ;$ bu., $\$ 4.10 ; 10$ bu. and up, $\$ 4.00$ per bu.

Navy Bean is the well known White Bush variety. A good yielder and very productive. Qt., 15c; pk., \$1.10; bu., \$4.00.

\section{Beans, Pole}

King of the Garden Lima is the only Pole Lima we offer. It is a vigorous grower. Pods 5 to 8 inches long. Beans large and of rich flavor. Pt., 15c; qt., 25c; pk., \$1.50; bu., \$5.50.

The Lazy Wife's Pole Bean is entirely stringless, of fine flavor, and bears an abundance of large pods which are fit for use until nearly ripe. A good, white shell bean for winter use. Pt., 15c; qt., 25c; pk., \$1.50; bu., \$5.50.

old Homestead or Kentucky Wonder. Very prolific, bears its pods in large clusters; pods green and often 8 to 10 inches long; nearly-round when young, and very crisp. Pt., 15c; qt., 25c; pk., \$1.50; but., \$5.50.

White Dutch Caseknife. A good shell bean, green or dry. An excellent corn bean. Pt., 15c; qt., $25 \mathrm{c} ;$ pk., \$1.10; bu., $\$ 4.00$.

Red Speckled Cut Short or Cornhill is a favorite sort and much in demand to plant among corn. The pods resemble the Bush Valentine. Pt., 10c; qt., 20c; pk., $\$ 1.00$; bu., $\$ 3.75$.

Add $8 \mathrm{c}$ per pint or $15 \mathrm{c}$ per quart to price on all beans if by mall.

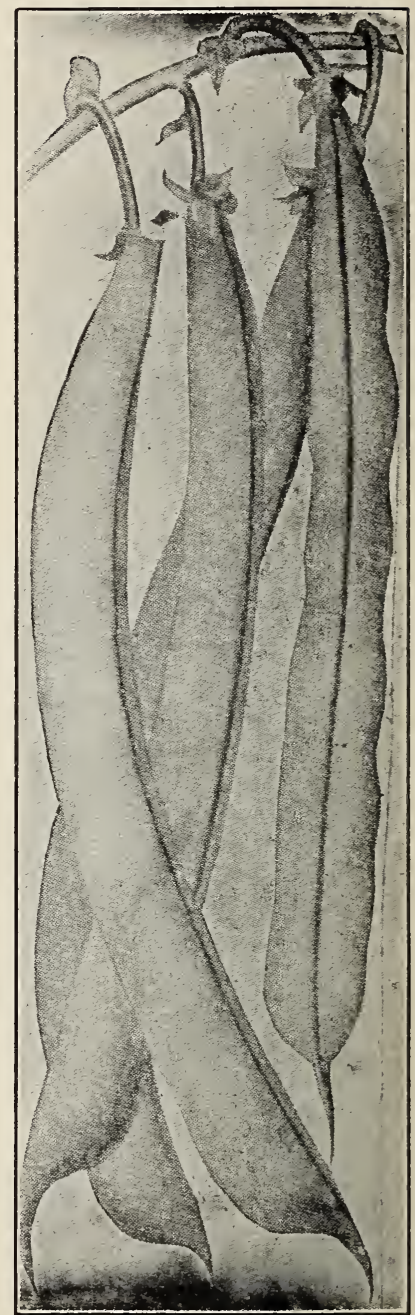




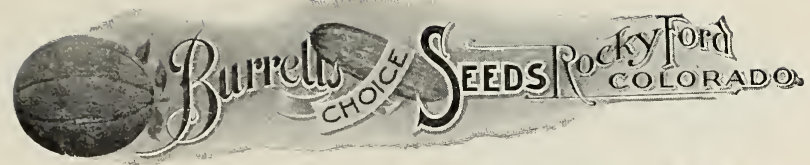

\section{Burrell's}

\section{Extra Select}

Stock Crosby's

\section{Egyptian Beet}

\section{A MONEY MAKER FOR MARKET MEN.}

I have a very fine strain of this finest first early beet. It is what you want ror early market or early home use. Very early, rich red, fine grained and $t$ e $n d e r$ flesh. The tops are small, $m$ a kin $\mathrm{g}$ fine bunches. They have a very distinctive bright red color, and are uniform in shape and appearance. The tap root is small. The type is well illustrated by the photograph.

Pkt., 5c; oz., 10c; 1/4

lb., 25c; lb., 70c; 10

lbs. and up, $60 \mathrm{c}$ per $\mathrm{lb}$.

\section{Burrell's Crimson Globe Beet}
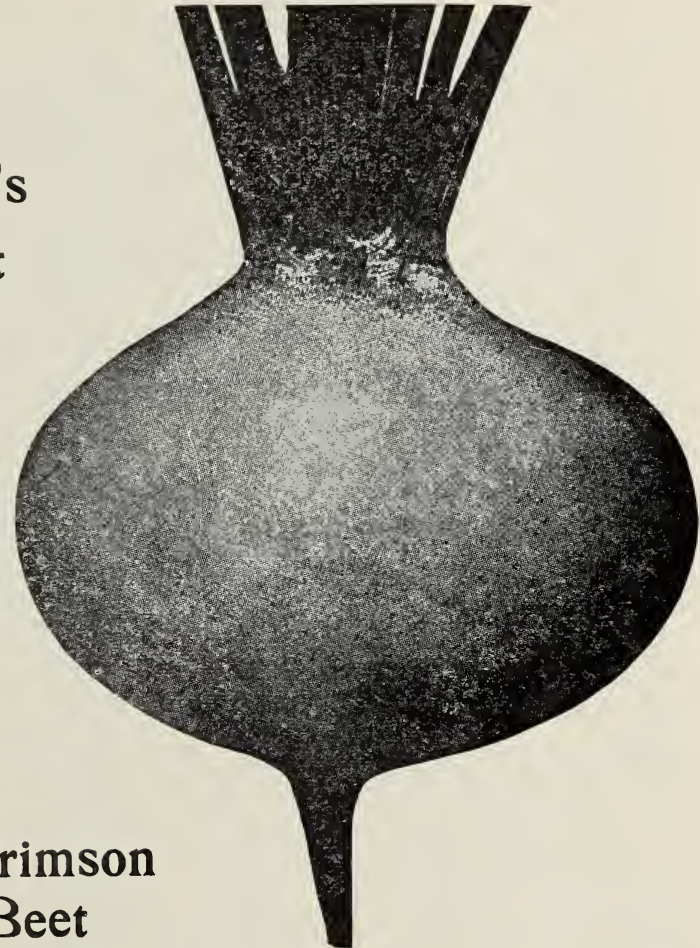

This very valuable second early sort is a fit companion to my strain of Crosby's Egyptian. The color is darker red, shape just a little more square shouldered, and a little deeper from base of top to tap root. The leaves are very dark red and tops small. It is a good beet to grow for late crop and keeps well when pitted until late in the spring. It is beautifully zoned. Will please you. Pkt., 5c; oz., 10c; 1/4 lb., $25 \mathrm{c} ; \mathrm{lb}$., 70c; 10 lbs. and up, 60c per Ib.

Early Eclipse. The tops are small, which admits of close planting. The roots are of globular shape. Flesh fine grained, very sweet, crisp and tender; dark red, zoned with lighter shade. Oz., 5c; 1/4 lb., 15c; lb., 45c; 5 lb. lots, $40 c$ per lb.

Edmand's Early Blood Turnip. The roots are of good form, round, with only one single tap root; the flesh is of a deep blood red color, and very sweet and tender. It is one of the best for the market gardener and for table use. Oz., 5c; 1/4 lb., 15c; lb., 40c; 5 lb., lots, 35c per lb.

Detroit Dark Red is an excellent beet for early planting. Beets are very good, dark red, turnip shaped, with small tops and small tap roots. Market gardeners will be well pleased if they plant heavily of these. Oz., 5c; $1 / 4$ lb., 15c; lb., 40c; 5 lb. lots, $35 \mathrm{c}$ per $\mathrm{lb}$.

Long Smooth Dark Blood. This is a very fine variety, especially where there may be a shortage of moisture, as it forms a long tap root quickly and is able to withstand much drouth. The color is rich dark red, and it makes a very attractive looking and equally as fine tasting pickles. A good long keeper. Oz., 5c; $1 / 4$ lb., 15c; lb., 40c; 5 lb. lots, 35c per Ib. Add $8 \mathrm{c}$ per pound if by mail. 


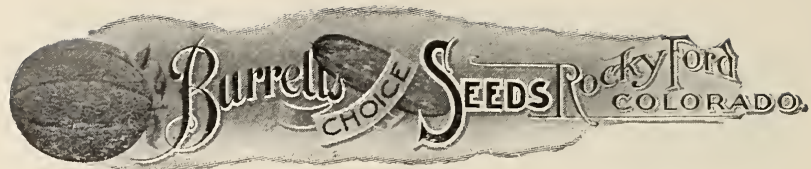

\section{Beets, Sugar and Mangel Wurzel}

White Klein Wanzleben Sugar has no equal, taking into consideration both tonnage per acre and sugar contents. It is more extensively grown than any other and will give good results under proper care in all localities. The yield here is usually about 15 tons to the acre and about 18 per cent sugar; though the best growers frequently get 20 to 30 tons per acre and tests have run as high as 26 per cent sugar. All stock feeders know that sugar makes fat and will realize the value as a stock food. Oz., 5c; 1/4 lb., 10c; lb., 20c; 10 lb. lots, 18c per lb.; 100 lb. lots, 15c per lb.

Lane's Imperial Sugar. This is a heavy yielder and well liked for stock feeding. It is very nutritious, and while not so rich in sugar as the above, yet runs from 8 to 13 per cent sugar, owing to the locality where grown. Oz., 5c; 1/4 lb., 10c: lb., 20c; 10 lb. lots, 18c per lb.; $100 \mathrm{lb}$. lots, 15c per lb.

Mammoth Long Red Mangel Wurzel is the heaviest yielder grown, and as it grows largely above ground, is easily harvested. Excellent for feeding stock. Oz., 5c; 1/4 lb., 10c; lb., 20c; 10 lb. lots, 15c per lb.; 100 lb. lots, 14c per lb.

Golden Tankard Mangel Wurzel is also a heavy yielder, but does not grow quite so long as Mammoth Long Red. Oz., 5c; $1 / 4$ lb.; 10c; Ib., 20c; 10 lb. lots, 15c per lb.; 100 lb. lots, 14c per lb.

\section{BROCCOLI.}

White Cape. Heads compact, good size and of a creamy white; one of the most certain to head. Pkt., 10c; oz., 30c; 1/4 lb., $\$ 1.00$.

BRUSSELS SPROUTS.

Best Imported Dwarf. Produces many sprouts close together; a good keeper. Pkt., 5c; oz., 10c; 1/4 lb., 35c; lb., \$1.35.

\section{CHICORY.}

Large Rooted. Used to mix with or as a substitute for coffee. CuItivate same as carrots. Pkt., 5c; oz., 10c; 1/4 lb., 25c; lb., 75c.

\section{COLLARDS.}

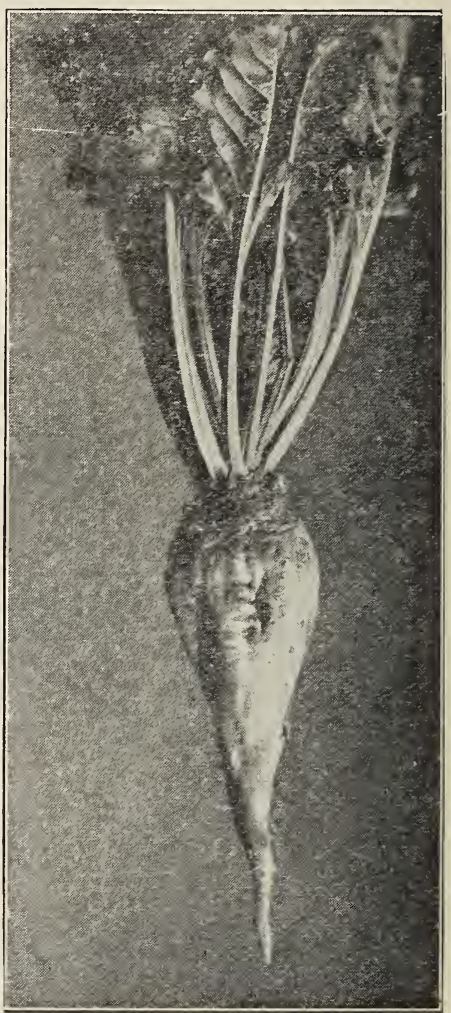

True Southern. Oz., 5c; 1/4 lb., 20c; lb., 65c. Add be per punilu il wy wall.

\section{CARROTS.}

Guerandi or Oxheart. This is an excellent variety, with broad shoulders, and as its name, Oxheart, indicates, it is not very long. The color is a rich orange and the quality will please you. Pkt., 5c; oz., 10c; 1/4 1b., 20c; lb., 60c; 5 lb. lots, 55c per lb.

Danver's Half Long. One of the most productive and best for field culture. Tops medium, roots dark orange color, large, of medium length, tapering abruptly at the point; very uniform; handsome; flesh deep orange; sweet and tender. Pkt., 5c; oz., 10c; 1/4 lb., 20c; lb., 60c; 5 lb. lots, 55c per lb.

Chantenay. Deep scarlet, of uniform shape, a heavy yielder and of fine table qualities; grows 5 to 7 inches long. Pkt., 5c; oz., 10c; 1/4 lb., 20c; lb., 60c; 5 lb. lots, $55 c$ per lb.

Large Yellow Belgian. Are long and slender; fully one-third to one-half of the length grows above the surface; they are, however, easily pulled. Oz., 5c; 1/4 1b., $15 \mathrm{c} ;$ lb., 35c; 5 lb. lots, 30c per lb.

Improved Long Orange. A standard late variety, handsome and uniform in shape; deep orange color; good flavor; yields heavily. Requires deep soil. Plants should stand 8 inches apart in 18 -inch drills for roots to attain full size. Oz., 5c; $1 / 4$ lb., 15c; lb., 40c; 5 lb. lots, 35c per lb.

White Vosges. Large, thick and short, a fine variety to grow for stock. Oz., 5c; 1/4 lb., 15c; lb., 40c; 5 lb. lots, 35c per lb. 


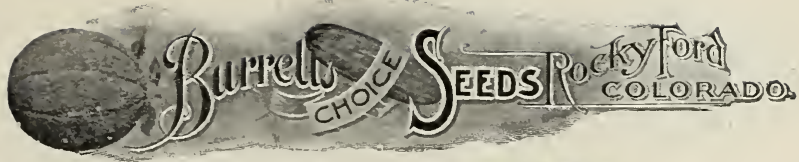

\section{Burrell's Large Charleston Wakefield Cabbage}

This finest large early cabbage is but a few days later than the very earliest small sorts, is a very stron thrifty grower, but little bothered by insects. The heads weigh from 6 to 10 pounds, sometimes more, are very solid and there is no sort more profitable for the early market. My seed is grown in

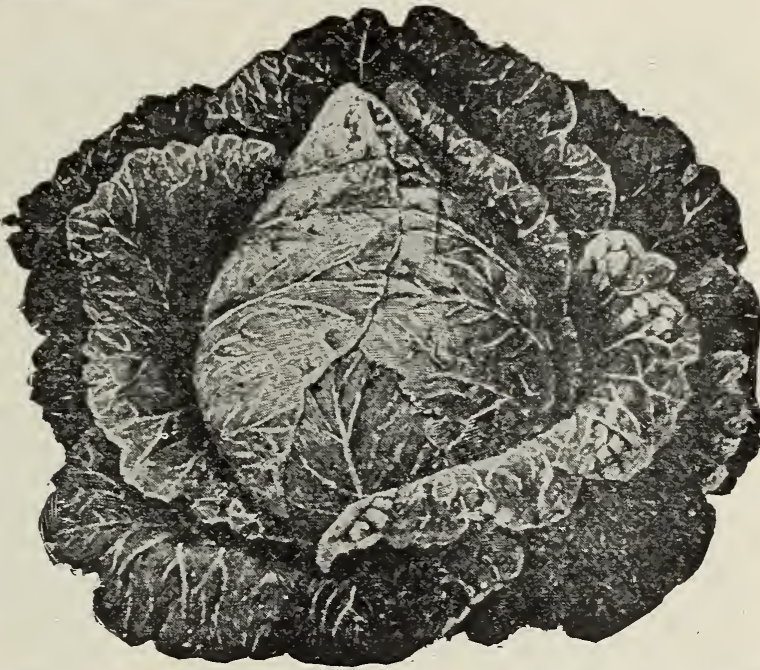
a section where there is nothing to be desired to permit the growing of the finest cabbage seed. You cannot buy better seed at any price. My price is a little more than ordinary seed, but as an ounce produces about 2,500 plants and a quarter pound enough for an acre, you cannot afford to let the slight difference in price keep you from planting this seed.

As one pound of seed contains 40,000 seeds, if this makes one head per hundred plants more than cheaper seed it means 400 more heads, at 5c each, means $\$ 20.00$ more. Pkt., 5c; oz., 20c: 1/4 lb., 60c; lb., \$2.00; 10 lbs. and up, \$1.90 per lb.

\section{Burrell's Special Stock Jersey Wakefield Cabbage}

This first early cabbage introduced a good many years ago still holds the place of first in earliness and quality combined. No stock is superior to what I now have of this strain. My seed is selected from the finest heads grown and matured under the most favorable conditions. Pkt., 5c; oz., 20c; 1/1 1b., 60c; lb., \$2.00; 10 lbs. and up, $\$ 1.90$ per $1 b$.

\section{EARLY AND SECOND EARLY POINTED HEAD SORTS.}

Early Etampes is a valuable first early sort that is fast winning favor. It forms fine hard pointed heads of extra quality. It grows close to the ground and has loose

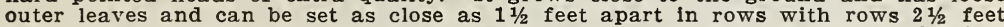
apart. Nearly every plant makes a head on good soil with careful cultivation. Pkt., 5c; oz., 15c; 1/4 lb., 45c; lb., \$1.60.

Extra Early Express. An extra early sort, in which the plants are compact, with round, thick leaves that form an oval head, which is astonishingly large for the size of plants. The heads are comparatively thicker and less pointed than those of the Jersey Wakefield, and are only slightly later than those of that sort. Pkt., 5c; oz., 15c; 1/4 lb., 50c; lb., \$1.60.

Early Winnigstadt. A distinct second early sort, and one of the best for general cultivation. Being very hardy, it is, therefore, less subject to wet or drouth, insects or disease. The heads are uniform in size, conica! in shape and very solid. It is valuable for early use, and on account of its solidity and short, thick leaves it makes also a good winter cabbage. Pkt., 5c; oz., 15c; 1/4 1b., 50c; lb., \$1.60. 


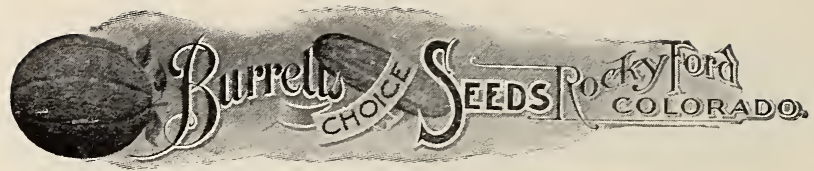

\section{Burrell's Excelsior Flat Dutch Cabbage}

This large, late variety is entitled to the name Excelsior. Practically every plant produces a fine head shaped like the illustration and welghing fifteen to twenty pounds under favorable conditions. The good report comes in from large numbers of my customers and the increasing number of orders has made it necessary for me to push it much more extensively. I often sell ten to twenty pounds of seed to one large grower. You will find this an excellent late sort and a good keeper. The heads are solid, stem short and quality extra.

Price: Pkt., 5c; oz., 20c; $1 / 4$ lb., 65c; lb., $\$ 2.40$; $10 \mathrm{lbs}$. and up, $\$ 2.30$ per 1 b.

Add $8 \mathrm{c}$ per pound if by mall.

\section{Burrell's Selected} Surehead Cabbage

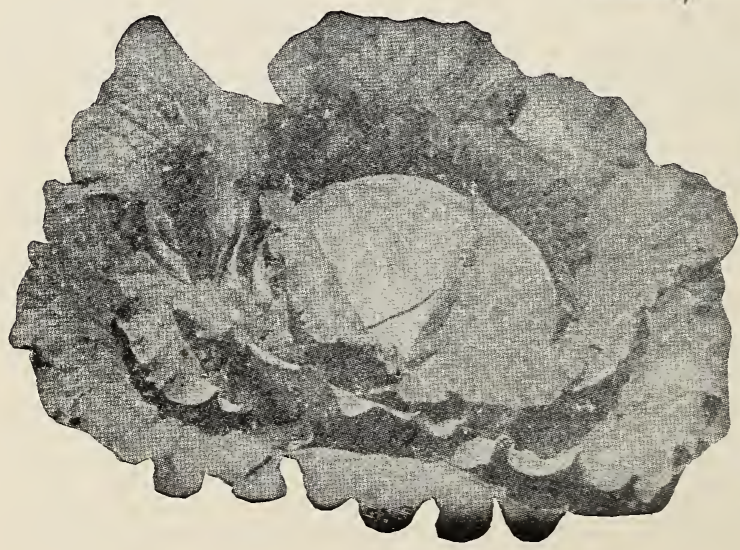

This excellent cabbage has been grown many years by thousands of successful gardeners with uniformly good results. Close, careful selection has kept it one of the best. The heads weigh about twelve pounds, are quite uniform in size, hard and of excellent quality, a good shipper. I recommend it either for your home garden or if you plant extensively for market.

Price: Pkt., 5c; oz., 20c; $1 / 4$ lb., 65e; lb. $\$ 2.40 ; 10 \mathrm{lbs}$. and up, $\$ 2.30$ per lb.

Add $8 \mathrm{c}$ per pound if by mall. 

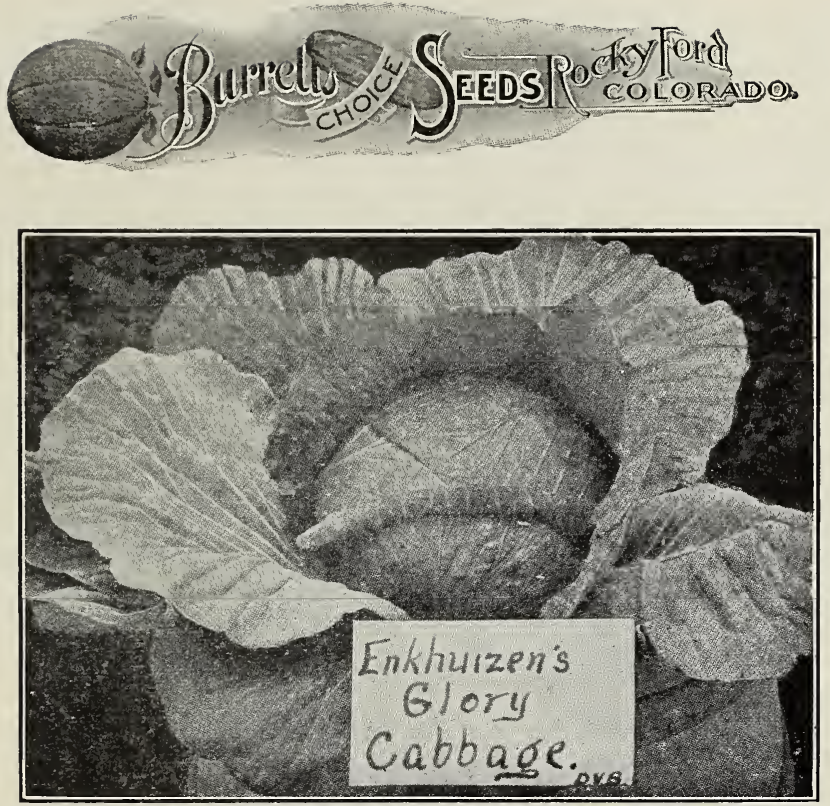

\section{Burrell's Enkhuizen Glory Cabbage}

This new sort originated near the shores of Zuyder Zee in Holland. I offer seed grown by the originator.

It is large, early, white, solid, new. The originators have this to say:

"Amongst many sorts of white cabbage, none of them combines these two desirable qualities of being early and large so well as the aforesaid sort. We can recommend this as a really early one (coming as early as the Early Dutch Flat), but at the same time making fine, large, ball-shaped heads, particularly attractive for market purposes.

"The plants are somewhat pale green, and in proportion to the whole, make very little outside leaves and fine large form, thin ribbed, hard heads.

"For the market one of the very best sorts."

This leaves little to be added except that I have thoroughly tested the variety and can recommend it as being a very fine sort, worthy your confidence. Do not hesitate to plant it extensively if you desire such a cabbage as is described above.

Price: Pkt., 5c; oz., 25c; 1/4 lb., 80c; lb., \$2.75; 10 lbs. and up, $\$ 2.50$ per $\mathrm{lb}$.

Add $8 \mathrm{c}$ per pound if by mall.

\section{Extra Fine All-Seasons Cabbage}

Plant it early for an early sort, late for a late sort, or your early planting will be suitable to use when the heads weigh 6 or 8 pounds and continue first class until they weigh 12 to 15 pounds. Then they stand a long time without bursting when many other sorts would burst open and spoil. It may well be called All Seasons. The heads are large and solid, round and flattened on top. Are ready to market as soon as the early fiat sorts.

My experience with this sort is so favorable that I cannot fall to list it among the sorts $I$ wish most to recommend.

Price: Pkt., 5c; oz., 20c; 1/4 lb., 65c; lb., \$2.40; 10 lbs. and up, \$2.25 per $1 b$.

Add $8 \mathrm{c}$ per pound if by mall.

I have single customers who purchase $\$ 1,000$ or more worth of seeds a year, and they always buy the best. Quality goes before prices 

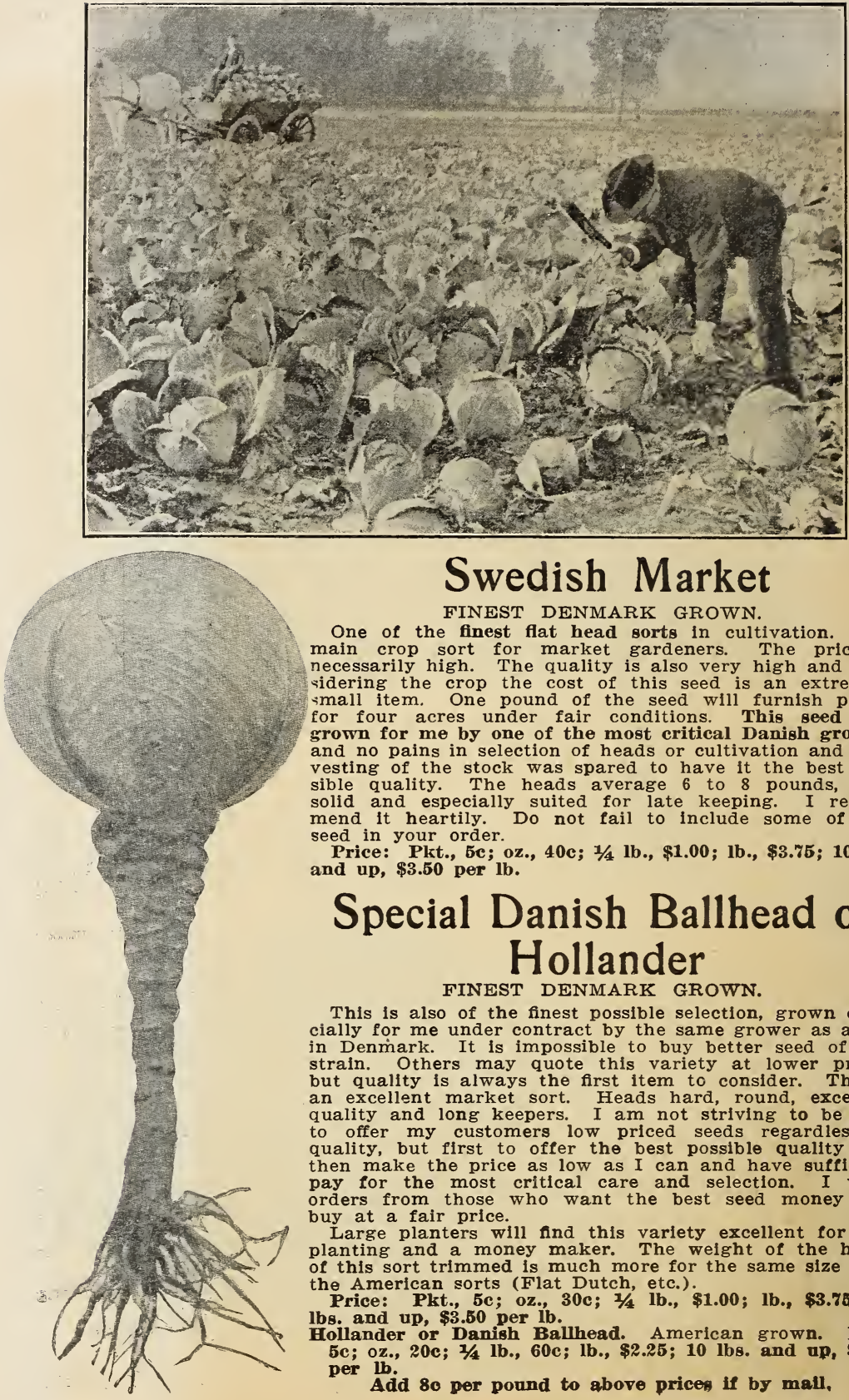

\section{Swedish Market}

FINEST DENMARK GROWN.

One of the finest flat head sorts in cultivation. The main crop sort for market gardeners. The price is necessarily high. The quality is also very high and considering the crop the cost of this seed is an extremely imall item. One pound of the seed will furnish plants for four acres under fair conditions. This seed was grown for me by one of the most critical Danish growers and no pains in selection of heads or cultivation and harvesting of the stock was spared to have it the best possible quality. The heads average 6 to 8 pounds, very solid and especially suited for late keeping. I recommend it heartily. Do not fail to include some of this seed in your order.

Price: Pkt., 5c; oz., 40c; 1/4 lb., \$1.00; lb., \$3.75; 10 lbs. and up, $\$ 3.50$ per $1 b$.

\section{Special Danish Ballhead or Hollander}

FINEST DENMARK GROWN.

This is also of the finest possible selection, grown especially for me under contract by the same grower as above in Denmark. It is impossible to buy better seed of this strain. Others may quote this variety at lower prices, but quality is always the first item to consider. This is an excellent market sort. Heads hard, round, excellent quality and long keepers. I am not striving to be able to offer my customers low priced seeds regardless of quality, but first to offer the best possible quality and then make the price as low as I can and have sufficient pay for the most critical care and selection. I want orders from those who want the best seed money will buy at a fair price.

Large planters will find this variety excellent for late planting and a money maker. The weight of the heads of this sort trimmed is much more for the same size than the American sorts (Flat Dutch, etc.).

Price: Pkt., 5c; oz., 30c; 1/4 lb., \$1.00; lb., \$3.75; 10 lbs. and up, $\$ 3.50$ per lb.

Hollander or Danish Ballhead. American grown. Pkt., 5c; $0 z_{.}, 20 \mathrm{c} ; 1 / 4$ lb., 60c; lb., $\$ 2.25 ; 10$ lbs. and up, $\$ 2.00$ per lb. Add 80 per pound to above prices if by mall. 

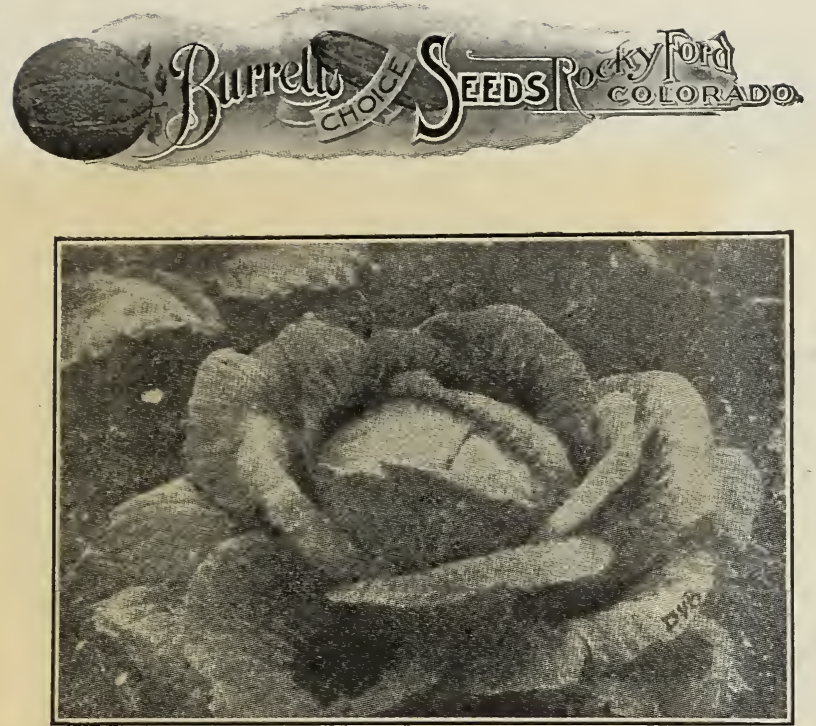

\section{Early All-Head or Faultless}

This is an excellent sort, producing a good solid head weighing six to eight pounds from practically every plant, under fair conditions. It is among the earliest sorts and is a very profitable sort to grow. The outer leaves are few and close planting can be made, as close as eighteen inches in the rows and rows two feet apart.

Pkt., 5c; oz., 20c; 1/4 lb., 50c; lb., \$2.00; 10 lbs. and up, \$1.80 per lb.

Early Spring. The Earliest Flat Head Variety. The heads have few outside leaves and these are small and grow so close to the head that they can be planted very close together. It is round in shape, slightly flattened, and very solid even before the cabbages attain their mature size. Pkt., 5c; 0z., 20c; 1/4 lb., 55c; 1b., \$1.80.

Early Summer. My seed of this variety was selected from large, solid, evenly sized heads of excellent quality, and is of known value. This is a special market gardeners' strain. Pkt., 5c; oz., 20c; 1/4 lb., 50c; lb., \$1.80.

Improved Succession. A sure heading, long keeping variety, about ten days later than the well known Early Summer, with larger and heavier heads. Pkt., 5c; oz., 20 ; $1 / 4$ lb., 50c; lb., $\$ 1.80$.

The Lupton. In this varlety, I have one which one of the best known cabbage seed growers (Mr. Lupton of Long Island), has named for himself. This alone is a great recommendation for it. I secure my seed direct from the originator, and $1 \mathrm{t}$ is right. The stalk is short. It is dark green, large size, solid and a long keeper. It is a sure header and will please you. Pkt., 5c; 0z., 15c; 1/4 1b., 50c; lb., $\$ 1.80$.

\section{Add 8c per pound if by mail.}

\section{THE SEED BUSINESS IS A VERY SERIOUS BUSINESS.}

The successful planter is very careful what he buys and who he buys from.

An ounce of Cabbage seed means, say 2,500 plants. If from good seed, and conditions are favorable, say 2,000 heads at $4 \mathrm{c}$ each net, or $\$ 80.00$. If poor, a loss.

An ounce of Tomato seed, say 3,000 plants, which is sufficient to set an acre. If good, this means from $\$ 125.00$ up to several hundred. If poor, a loss.

A pound of Cantaloupe seed plants an acre. An acre of good Cantaloupes pays from $\$ 100$ to $\$ 500$, sometimes more. If poor seed, the result may be the loss of labor, use of land, etc., and to this the disappointment.

The seedsman who sells the good seed keeps the customer and gets his neighbor for a customer. The one who sells the poor seed loses his customer and he influences others not to order.

I have gardened for market for years and know the value of good seed. Now I am proud to say my seed business is the most rapidly growing seed business in the United States. I credit all its growth to the fact that I am pleasing you who are my customers and I thank you very much for your increased orders and the fact that you recommend that others buy of me. I am better than ever prepared to take care of your orders this year. 

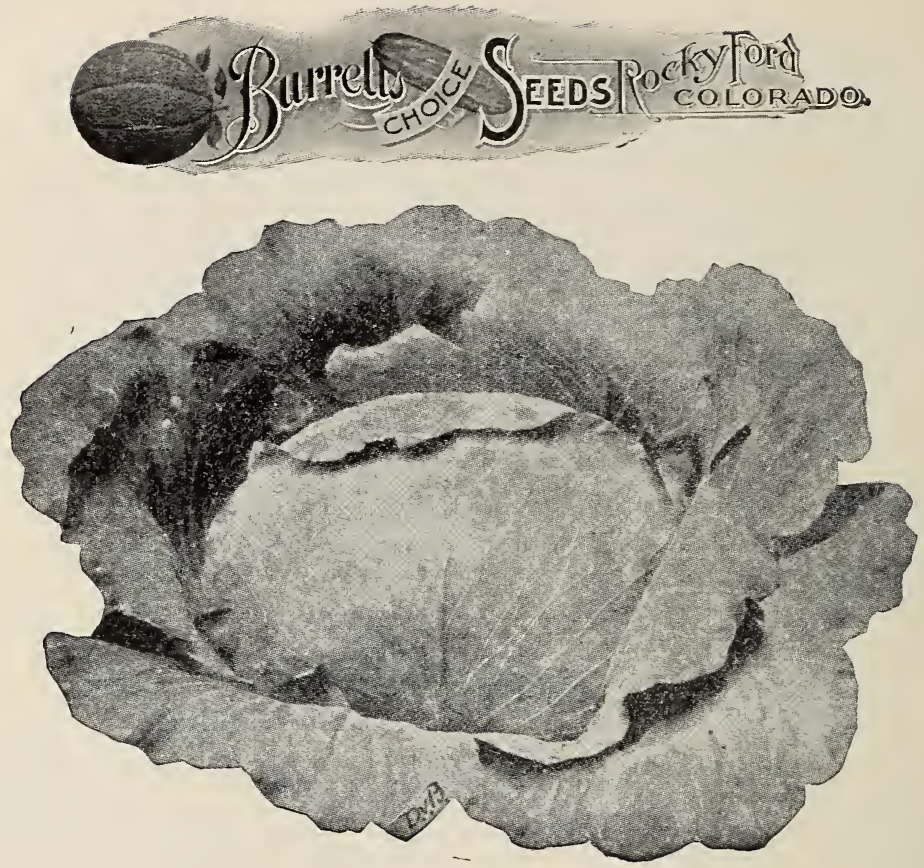

\section{Fottlers' Brunswick Short-Stemmed Cabbage}

THIS IS THE GREATEST OF ALI SAUER KRAUT CABBAGES. Under ordinary conditions it will produce nearly double the crop of the average varieties. It is a very sure header and the heads average about fifteen pounds.

In season it is very little later than the early pointed head sorts, but the time of maturity can be controlled by the time of starting the plants.

It is not a good keeper and $I$ do not recommend it for a winter cabbage, but I recommend that you plant practically all your acreage to this if you grow under contract for a Kraut Factory at a stated price per ton.

Pkt., 5c; oz., 20c; $1 / 4$ lb., 55c; lb., $\$ 2.00 ; 10 \mathrm{lbs}$. and up, $\$ 1.80$ per lb.

Large Late Drumhead, Resembles Flat Dutch. Largely grown in the Southwest. Stands heat well and is a sure header. Pkt., 5c; oz., 20c; 1/4 lb., 50c; lb., \$1.80. St. Louis Late Market. This is a favorite sort among market gardeners around St. Louls. It is very solid, and produces heads weighing from fifteen to eighteen pounds; is a sure keeper, and the quality extra. Pkt., 5c; oz., 15c; 1/4 lb., 45c; lb., \$1.60.

Marblehead Mammoth. This is the largest cabbage grown, heads often reaching the weight of fifty to sixty pounds on rich soll. A great cabbage to grow for exhibition, and of fair quality. Its size alone should recommend it. Pkt., 5c; oz., 15c; $1 / 4$ lb., 45c; lb., \$1.60.

Perfection Drumhead Savoy. Size of the Drumhead, curled leaves of the Savoy. Market gardeners usually find it profitable to provide a limited quantity for discriminating customers. Pkt., 5c; oz., 15c; 1/4 lb., 50c; lb., \$1.60. 

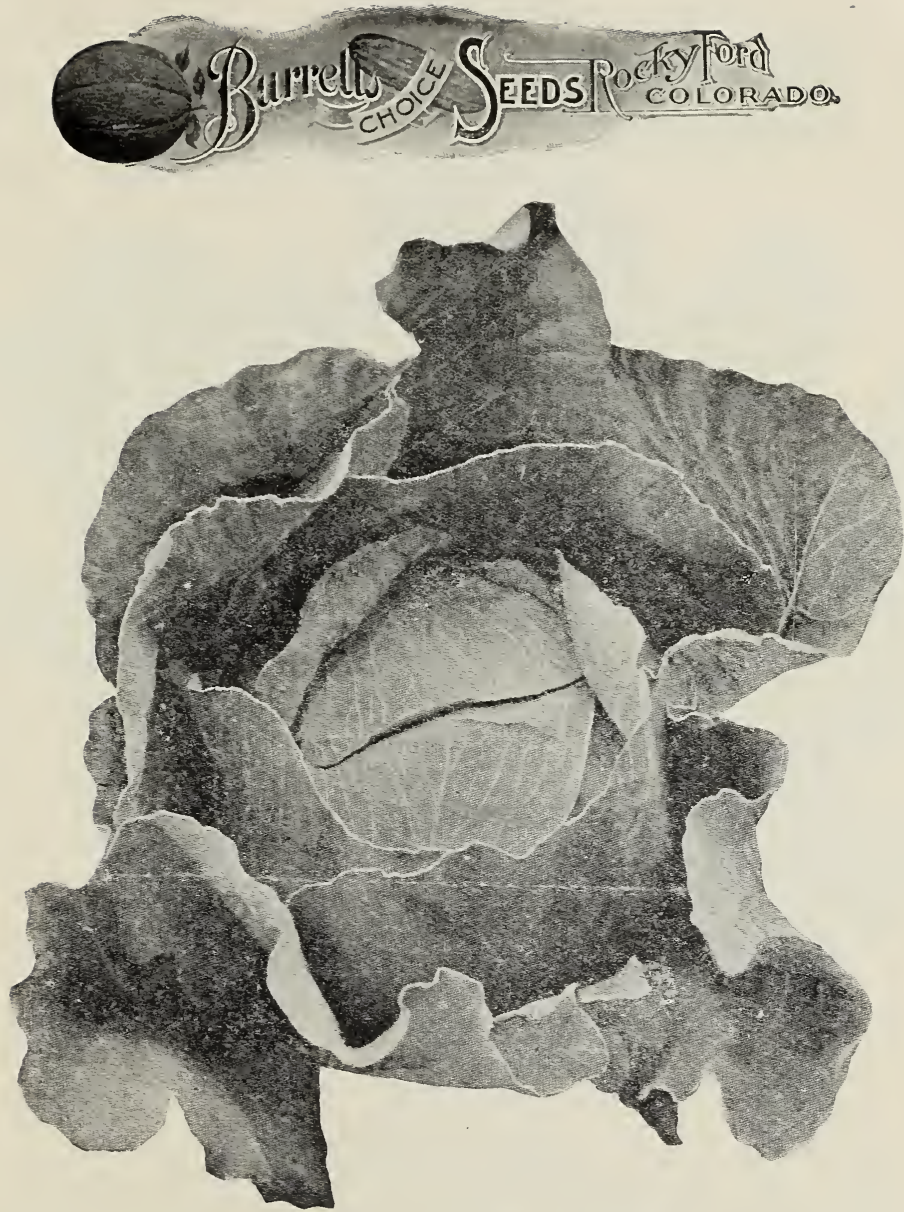

\section{Special Early Flat Dutch Cabbage}

Our seed of this variety is giving such resn'ts that the demand is growing very rapidly and to meet it and still more large $y$ increase it we have increased our supply and are able to make very attractive prices.

The heads weigh eight to ten pounds, are very even in size, solid, and of good flavor.

This is one of the best second early and stands a long time without bursting.
Pkt., 5c; oz., 15c; $1 / 4$ lb., 45c; lb., \$1.50; 10 lbs., $\$ 1.40$ per lb.; 25 lbs. and up $\$ 1.30$ per $\mathbf{l b}$.

\section{Premium Late Flat Dutch Cabbage}

This standard sort is well known and our sales always run high. The heads are large, flat and of good quality. Pkt., 5c; oz., 15c; 1/4 lb., 45c; lb., \$1.50; 10 lbs., $\$ 1.40$ per lb.; 25 lbs. and up, $\$ 1.30$ per lb.

I am making a specialty of High Class Cabbage Seed and am well prepared to take care of your orders. Market growers especially will be pleased with my seed and that means they are just what is wanted for home gardens. 


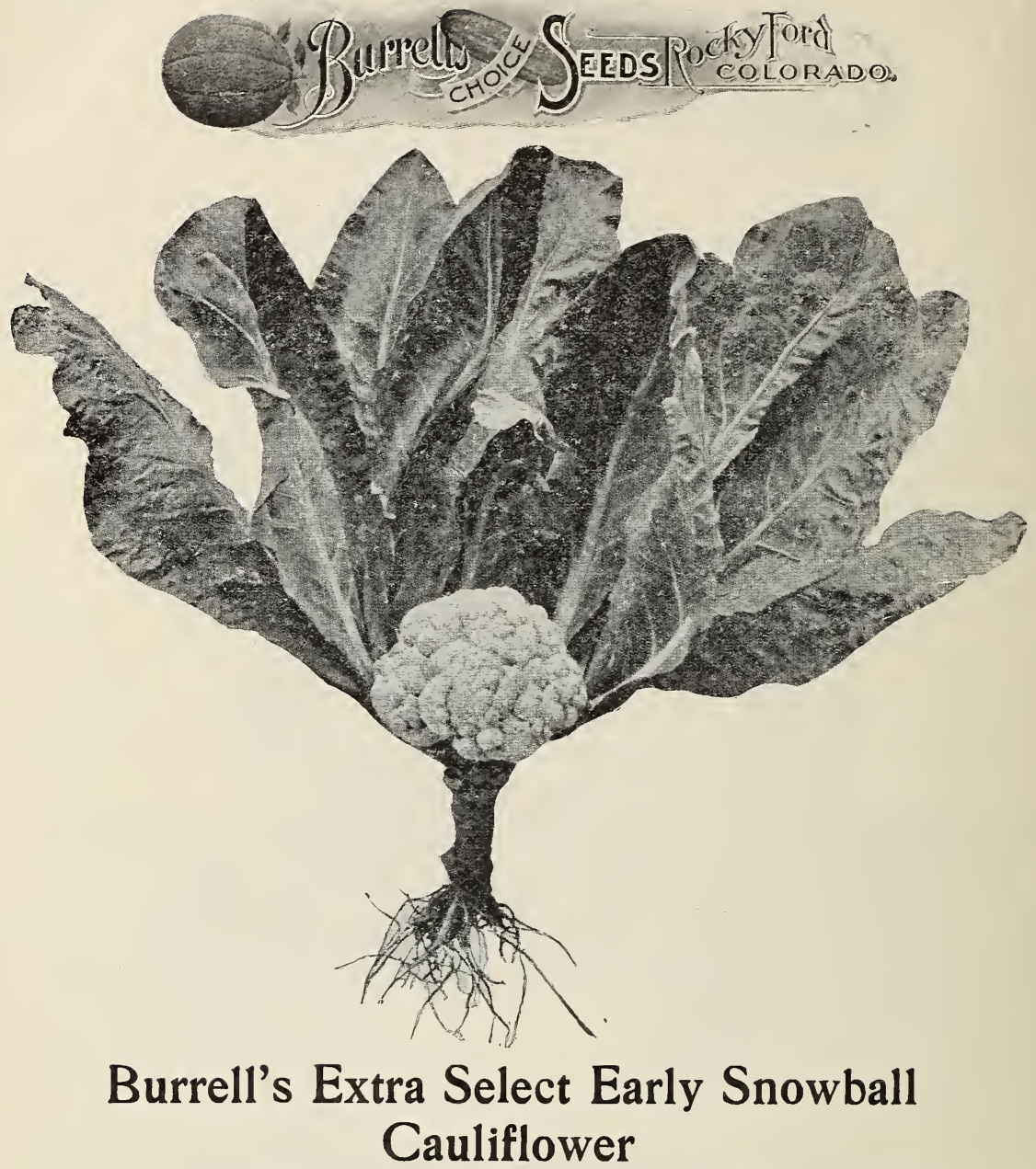

This variety is the highest attainment in the development of the caulfflower. This seed is grown for me by an expert specialist in Denmark. Every care is taken to have the seed right. The heads are selected for a close white curd, solid and uniform.

The cultivation is done in the most thorough manner and the seed is then selected from the single plants which continue to show the highest development. The seed is then graded and I receive only the largest, best developed seeds. This special pains is of great value to my customers, as in this crop so much depends upon the quality of the seed. This sort is remarkable for it extreme earliness, sureness to produce fine, solid heads with a close white curd. The leaves are produced in sufficient quantity to tie nicely over the head while the curd is small and permit them to blanch very white. The heads are round and thick, often weighing six to ten pounds before the curd begins to separate. No better strain can be procured. Market growers especially can plant this seed and be assured that it is the seed which will give them the best possible results.

Considering the extreme care taken and the crop results, the price is right.

Price: Plxt., 15c; 1/8 oz., 45c; 1/4 oz., 80c; oz., \$3.00; 1/4 lb., $\$ 10.00$. 

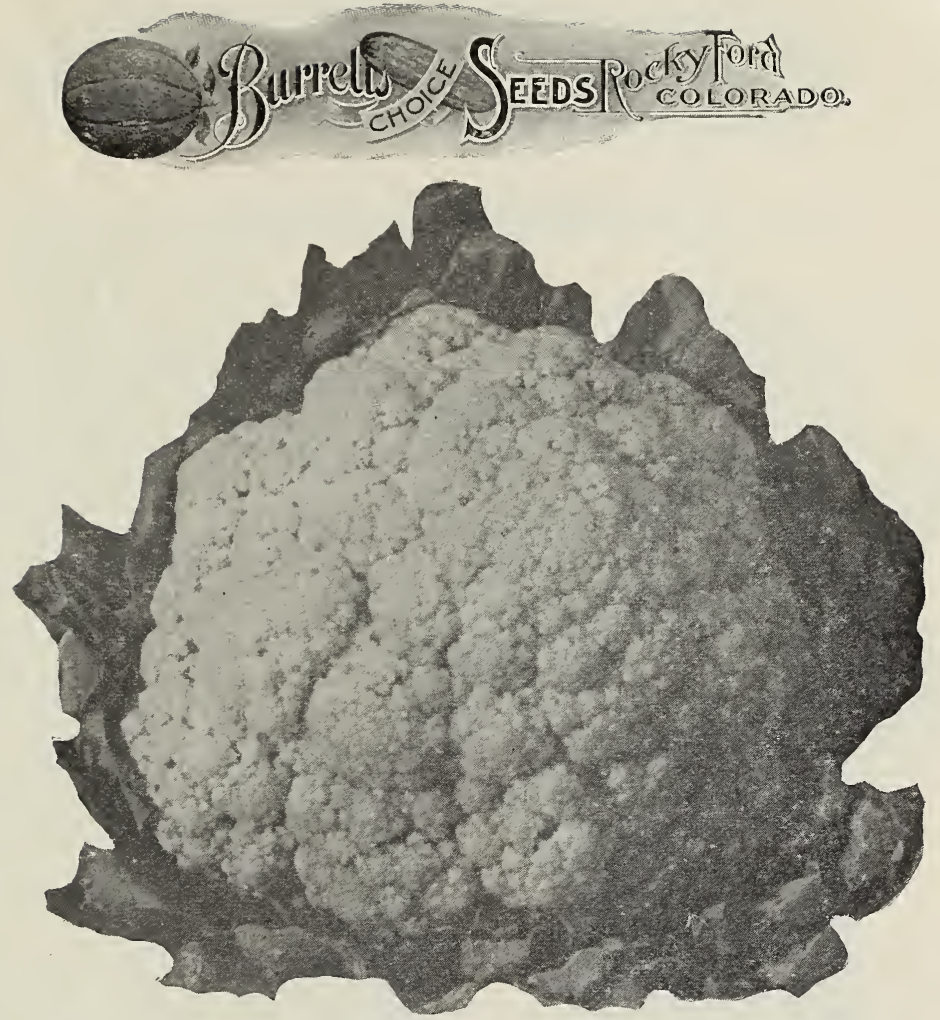

\section{Early Short Stemmed Danish Giant Cauliflower}

This is an early sort, a sure header and one of the best produced. While not quite so early as Burrell's Extra Select Early Snowball it is equal in quality and no matter how critical your trade or how much you have been able to do in producing cauliflower you can expect to equal your best record with this seed except as stated as to earliness. Price: Pkt., 15c; 1/8 oz., 45c; 1/4 oz., 80c; oz., \$3.00; 1/4 lb., \$10.

\section{Select Early Dwarf Erfurt Cauliflower \\ of dwarf hablt, close, compact growth, a sure header, curd close and whlte;} very rellable. Pkt., 10c; 1/4 oz., 60c; oz., $\$ 2.00 ; 1 / 4$ lb., $\$ 7.00$.

\section{Henderson's Early Snowball Cauliflower}

Its dware hablt and short outer leaves allow it to be planted as close as 18 to 20 inches apart each wayl. Very valuable for market gardeners. My stock is as fine as possible to secure. Pkt., 15c; 1/8 oz., 45c; 1/4 0z., 80c; 0z., \$3.00; $1 / 416 ., \$ 10.00$.

Remember, caullflower seed must be right or very poor results will be had. Rellable seed will always be worth the prices I ask. Cheap seed of questlonable quallty can be had at low prices, but you cannot afford to take the risk. 

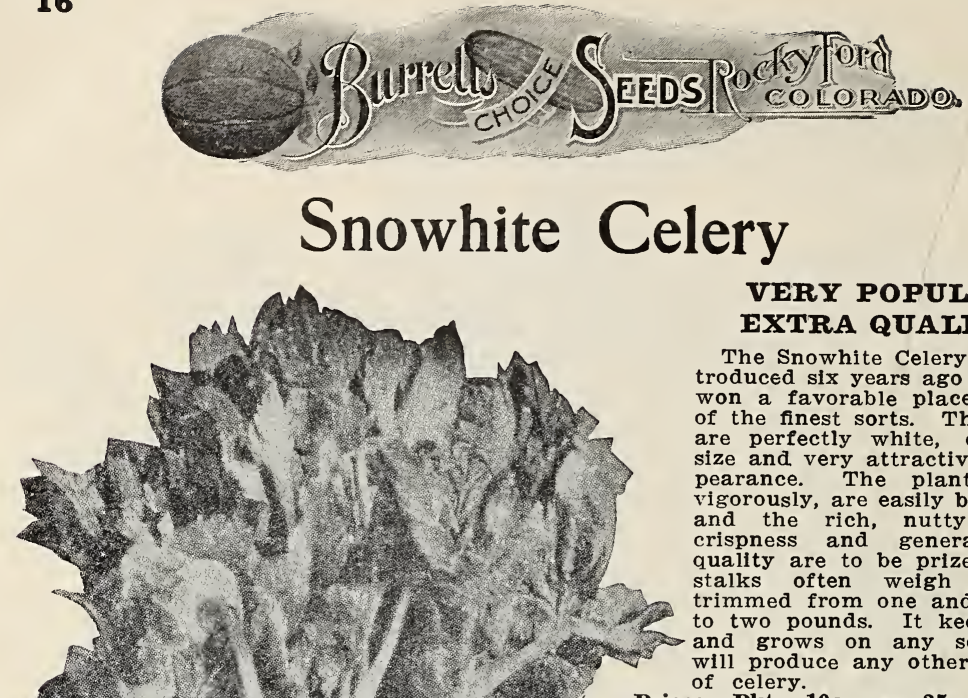

\section{VERY POPULAR EXTRA QUALITY}

The Snowhite Celery was introduced six years ago and has won a favorable place as one of the finest sorts. The stalks are perfectly white, of good size and very attractive in appearance. The plants grow vigorously, are easily blanched, and the rich, nutty flavor, crispness and general high quality are to be prized. The stalks often weigh whe $n$ trimmed from one and a half to two pounds. It keeps well and grows on any soll that will produce any other variety of celery.

Price: Pkt., 10c; oz., 25c; 1/4 lb., $80 \mathrm{c}$; lb., \$2.75; 5 lbs. and up, $\$ 2.50$ per lb.

Add $8 \mathrm{c}$ per pound if by mall.

\section{Golden Self Blanching Celery, Burrell's High Grade Stock}

This variety is now quite popular, being one of the most extensively grown sorts both for market and home gardens.

The growth is heavy and compact, the stalks are thick, crisp and brittle. The hearts are large, solld and blanch a beautiful golden color, hence its name. The flavor is very attractive. It gives excellent satisfaction and many prefer it to all others.

Price: Pkt., 10c; oz., 30c; 1/4 lb., $\$ 1.10$; lb., $\$ 4.00$; 5 lbs. and up, $\$ 3.75$ per lb.

Add $8 \mathrm{c}$ per pound if by mail.

\section{Giant Pascal Celery}

This is one of the most popular varieties for winter use. It is a very good keeper and properly stored can be kept until late in the winter or even until spring.

Giant Pascal is of vigorous growth, making large, heavy, thick stalks which remain green until blanched by some artificial means, either by earthing or storing for the winter.

It blanches to a creamy yellow when the stalks are quite brittle, entirely stringless and very crisp.

I have sold large lots of this seed to market growers, who report excellent results.

Price: Pkt., 5c; oz., 20c; 1/4 lb., 60c; lb., \$2.00; 5 lbs, and up, $\$ 1.75$ per $l b$.

Add $8 \mathrm{c}$ per pound if by mall. 


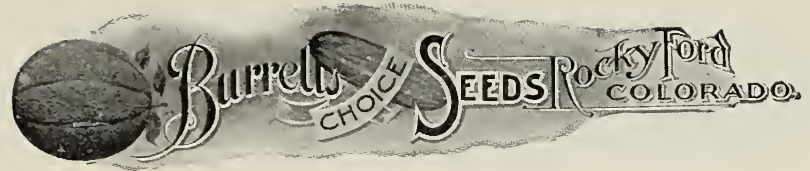

\section{Selected White Plume Celery}

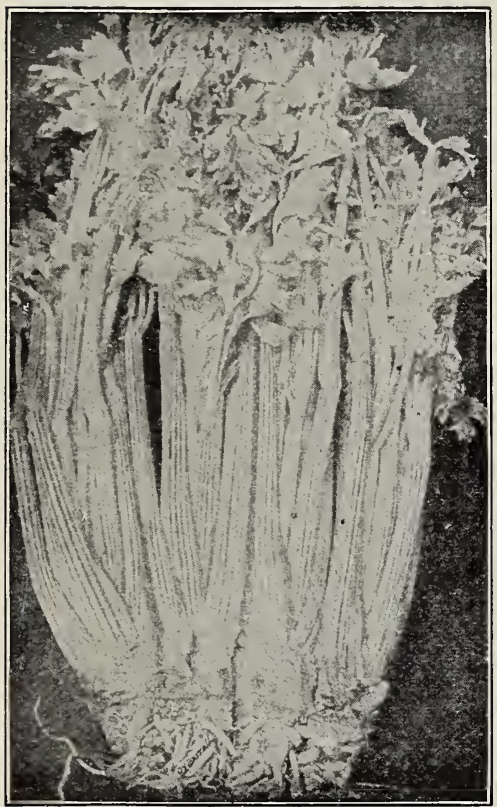

This is the earliest sort and most easily blanched. The plant is a rapid grower and should be tied loosely together as soon as five or six inches high and earthed up to push the growth and blanching, also to insure close a t ractive shaped bunches.

My seed is of extra quality and a.lways gives good results. Pkt., 5c; oz., 15c; 1/4 lb., 50c; lb., \$1.75; $5 \mathrm{lb}$. lots, $\$ 1.60$ per lb.

Golden Heart or Golden Dwarf. An excellent standard sort, solid, a good keeper and of a fine nutty flavor. A late variety, one of the best for market gardeners. Pkt., 5c; oz., 15c; 1/4 lb., 50c; lb., \$1.75; 5 lb. lots, $\$ 1.60$ per lb.

Kalamazoo. Half dwarf, white; grown very extensively at Kalamazoo, Mich., where celery growing is carried on to the extent of many hundreds of cars annually. Pkt., 5c; oz., 15c; 1/4 lb., 50c: Ib., $\$ 1.75 ; 5$ lb. lots, $\$ 1.60$ per lb.

Perfection Heartwell. Large, golden yellow heart of very superior quality. A good market sort. Pkt., 5c: oz., 15c; 1/4 lb., 50c; lb., \$1.75; 5 lb. lots, $\$ 1.60$ per lb.

Pink Plume. Identical in quality with White Plume, but the stalks are an attractive creamy pink. It has that rich "nutty flavor" and is very good. Pkt., 5c; oz., 15c; $1 / 4$ lb., 50c; lb., \$1.75; 5 lb. lots, \$1.60 per lb.

Add $8 \mathrm{c}$ per pound to all prices on celery if by mail.

\section{Celeriac}

Add 8c per pound if by mall.

Giant Smooth Prague. A very large and smooth variety, free from side roots. A desirable sort for market, and an excellent keeper. Pkt., 5c; oz., 10c; 1/4 lb., 35c; lb., \$1.20; 5 lb. lots, \$1.10 per 1 b.

\section{Cress}

Add $8 \mathrm{c}$ per pound if by mall.

True Water. Thrives only when the roots and stems are very moist. It has fine flavor and should be grown wherever it can be given a sufficient supply of pure water. Pkt., 5c; oz., 25c.

Double Curled. This is very early and of fine flavor Oz., 5c; 1/4 1b., 15c; lb., 50c. 

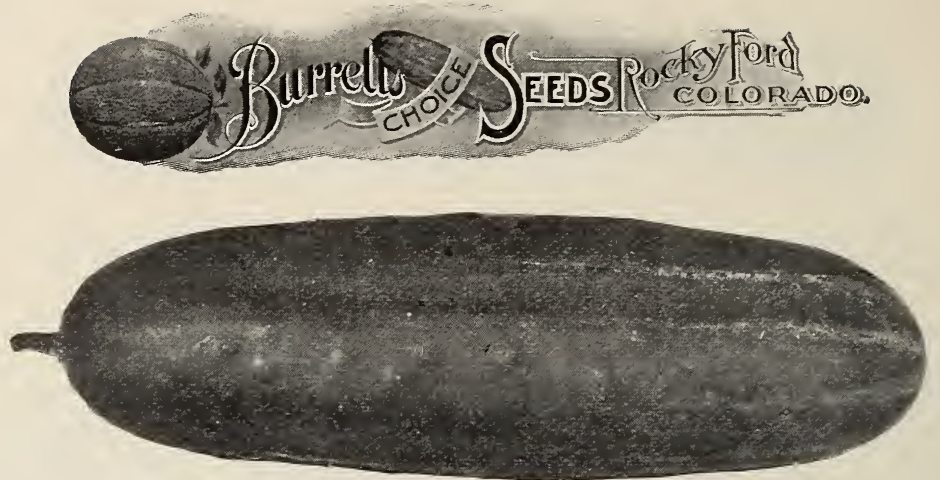

\section{Burrell's Klondike Cucumber}

This is one of my special items of my own introduction. It is a pleasure tn be able to state that it has through merit and without extensive advertising worked into the favor of market growers until it is now one of the leaders. It is without an equal for outdoor growing for slicing, producing specimens equal to the finest hothouse products under favorable conditions. It is a very hardy grower. Early, yields abundantly and withstands unfavorable weather conditions even when most sorts fail. When ready to ship the shape averages as in cut; color dark green with pale green stripes from the blossom end about one-third the length; flesh white and crisp, of excellent flavor; length about seven to eight inches. No sort produces more uniform fruits. Many single customers purchase from 100 to 500 pounds, and some more. Pkt., 5c; oz., 10c; 1/4 lb., 25c; lb., 85c; 10 to 20 lbs., 80c per lb.; 20 to 50 lbs., 75c per lb.; 50 lbs. and up, 70c per lb.

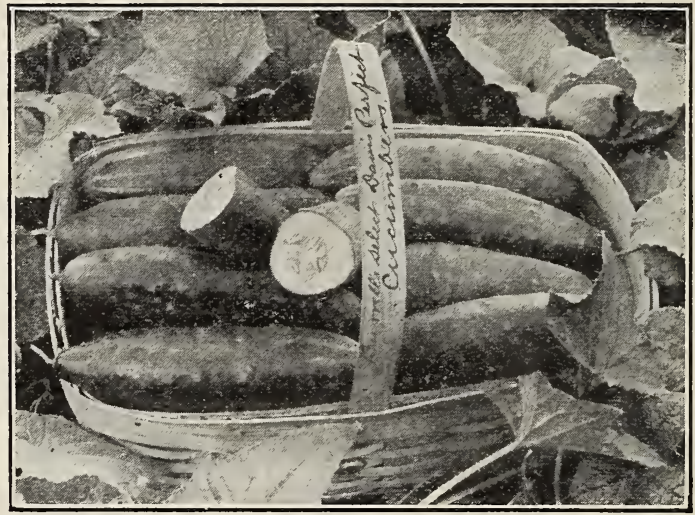

\section{Davis Perfect Cucumber-Burrell's Special Stock}

This very valuable new sort was introduced in 1906 and I immediately secured from the introducer a considerable quantity of the seed. This I carefully planted and from the crop I selected the finest specimens for stock seed. I have kept up this selection each year and this year I grew a large acreage and am pleased to say I have seed of this valuable sort to offer my customers at prices which surely merit your orders when you consider it is one of the best possible to secure. The cucumbers shown in above basket are Davis Perfect. This cucumber is exactly the same color as Burrell's Klondike, being dark green. Length about ten inches when suitable to ship and size quite uniform. It is an excellent sort either for hothouse or outdoor culture.

Grown out of doors the color resembles hot house grown stock and it sells well in competition with them. Pkt., 5c; oz., 10c; 1/4 lb., 25c; lb., 85c; 10 lbs. and up, 80c per lb. 

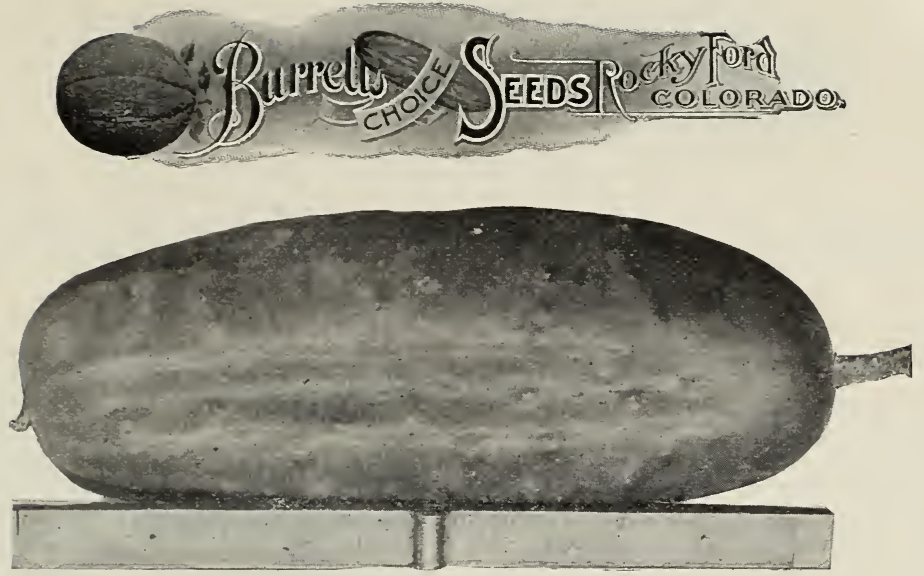

\section{Burrell's Earliest of All Cucumber}

This is the earliest type of white spine grown, being as early as Early Russian. While so early the fruits are of fine quality and the color an attractive dark green changing to white when ripe.

For pickling it produces fruits which when suitable for bottle goods are straight, square ended and very firm. One of the large pickling companies writes me that they find it the best sort they have ever grown for this purpose and back it up with a large order for seed. The single specimen shown above gives you the type.

Price: Pkt., 5c; oz., 10c; 1/4 lb., 25c; lb., 75c; $10 \mathrm{lbs}$. and up to $20 \mathrm{lbs}$., 70c per Ib.; 20 Ibs. and up, $65 \mathrm{c}$ per $\mathrm{lb}$.

\section{Fordhook Famous Cucumber}

This is an excellent type of the long white spines. It produces more uniform fruits than any other extra large type. It is a vigorous grower; the quality is excellent and after growing it extensively I recommend it as very good.

Pkt., 5c; 0z., 10c; 1/4 lb., 25c; lb., 85c; 10 lbs. up to 20 lbs., 80c per lb.; 20 lbs. and up, $75 \mathrm{c}$ per $1 \mathrm{~b}$.

\section{Burrell's Select Tailby's Hybrid Cucumber}

I have also grown an excellent crop of this well-known variety which I have specially selected to be able to offer as good as it is possible to secure. The fruits resemble Burrell's Klondike except they are some thicker and about a week later. It is a cross between the Long Green and a White Spine sort and has won a place which many market growers consider others cannot fill. It is an excellent shipper and yields abundantly.

Price: Pkt., 5c; oz., 10c; 1/4 lb., 25c; lb., 75c; 10 lbs., \$7.00.

Cool and Crisp. A strain of the White Spine, but larger and more cylindrical. Very early and exceedingly prolific. While it is esteemed most highly as a pickling sort, it is one of the very best for slicing, being tender, crisp and of fine flavor. Pkt., 5c; oz., 10c; 1/4 lb., 25c; lb., 75c; 10 lbs. and up to 20 lbs., 70c per lb.; 201 lbs. and up, $65 \mathrm{c}$ per $\mathrm{Ib}$.

Extra Early White Spine. This type is about midway between my Klondike and Earliest of All; the quality is excellent. Very good for small pickles, dill pickles or slicing. Pkt., 5c; oz., 10c; $1 / 4$ lb., 25c; lb., 80c; 10 lbs. and up to 20 Ibs., 75c per Ib.; 20 lbs. and up, 70e per $1 b$.

Add $8 \mathrm{c}$ per pound if by mail. 


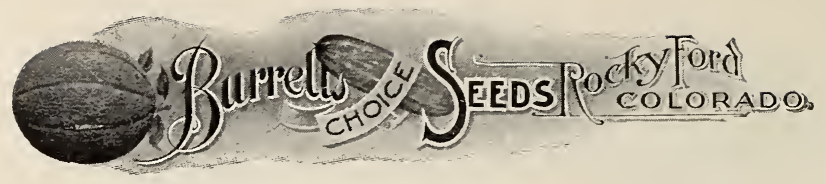

\section{Cucumbers (Continued)}

In proved Irlington White Spine. This strain of White Spine produces fine green fiom sight to ten inches Ing when in slicing condition that are cxtra shitll. $\cdots$ lowk woll in market and retain their attrartice appearanre a Iong

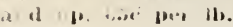

Fxtra long White spine. Fruits about two inches longer than the Arlington and square ended, otherwise much the same. Pkt., 5c; oz., 10c; 1/4 Ib., 20c; lb., r0c; 10 lbs. and up, $65 \mathrm{c}$ per $1 \mathrm{~b}$.

Cumberland. The New Cumberland combines prolificacy and vigorous growth with beauty and uniformity. It is of the hardy, white spine type, a rapid and vigornus grower, and very prolific in fruit. The pickles differ from all other hardy sorts in being thickly set with fine spines over almost the entire surface. During the whole period of growth from the time they first set until fully grown, the form is exceptionally straight and symmetrical, thus being as choice for slicing as for pickles. The flesh is firm, very crisp and tender at all stages. Pkt., 5c; oz., 10c; $1 / 4$ lb., 20c; lb., 70c; 10 lbs, and up, 65c per $1 \mathrm{~b}$.

Improved Long Green. My stock of this is very fine. The fruits are long, often fifteen to eighteen inches when fully matured. This long, slender, all-the-same shape makes it, when small, one of the finest sorts grown for pickles. It is tender and crisp and is an excellent sort for slicing, as it retains its dark green color for a long time. I offer you extra value in this seed. This seed is more extensively grown than any other. If you order early you are sure to get it. Pkt., 5c; oz., 10c; 1/4 lb., 30c; lb., $\$ 1.00 ; 10 \mathrm{lbs}$. and up, 90c per $1 \mathrm{~b}$.

Early Cluster. Vines vigorous, producing the bulk of the crop near the roots in a cluster. Fruits shaped uniformly; thick, square ends. Dark green at stem and changing to lighter at blossom end. Very productive and a good sort for pickles. Pkt., 5c; oz., 10c; 1/4 lb., 30c; lb., \$1.00; 10 lbs. and up, 85c per lb.

Early Siberian. One of the earliest cucumbers grown. Only three to four inches long, thick and produced in pairs; quite solid and crisp, with but few seeds. Pkt., 5c; oz., 10c; $1 / 4$ lb., 30c; lb., $\$ 1.00 ; 10$ lbs. and up, 85c per $1 b$.

Early Frame or Short Green. An excellent sort both for pickling and slicing. Fruits uniform, straight and attractive. Bright green, tender, crisp and a good yielder. Pkt., 5c; oz., 10c; 1/4 1b., 20c; lb., 70c; 10 lbs. and up, 65c per lb.

Chicago or Westerfield Pickling. A variety much esteemed above all others by Chicago market gardeners, and grown extensively for the large pickling establishments in that vicinity. Fruits medium length, pointed at each end, with large and prominent spines; color a deep green. It combines all the good qualities of an early cucumber. Pkt., 5c; oz., 10c; 1/4 lb., 20c; lb., 70c; 10 lbs. and up, 653 per lb.

Green Prolific or Boston Pickling. A distinct variety. A favorite with pickle growers and commercial gardeners, and good for table use. Quite productive. Fruit small and uniform in size. Pkt., 5c; oz., 10c; 1/4 lb., 20c; 1b., \%0c; 10 lbs. and up, 65e per $1 \mathrm{~b}$.

Fordhook Pickling. Resembles the Cool and Crisp, but is not a type of White Spine, bearing long, attractive fruits in abundance; crisp, tender and of desirable quality. Pkt., 5c; oz., 10c; 1/4 lb., 20c; lb., 70c; 10 ibs. and up, 65c per lb.

Japanese Climbing. Produces long, evenly shaped, crisp and tender fruits in great abundance. The vine has a much greater tendency than any other sort to faster itself to any objects over which it may grow, and hence its name. In the smal. garden where space is limited, it may be trailed on trellises to good advantage Fine for either pickles or slicing. Pkt., 5c; oz., 15c; 1/4 lb., 50c; lb., \$1.50.

Gherkin. The Gherkin is not a cucumber proper, but a little rough, prickly fruit that grows on a pretty vine, with leaves something like those of a watermelon vine. It is liked for pickling, and is known as the West India Gherkin. Pkt., 5c; oz., 15c; 1/4 lb., 40c; lb., \$1.50.

Add $8 \mathrm{c}$ per lb. to above prices if by mail. 


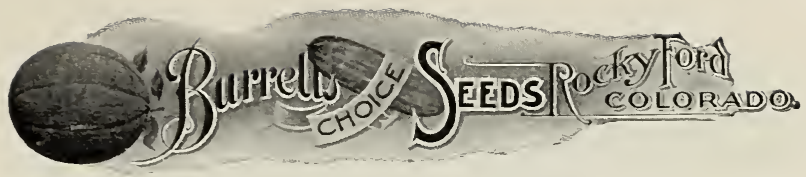

\section{Sweet Corn--Country Gentleman}

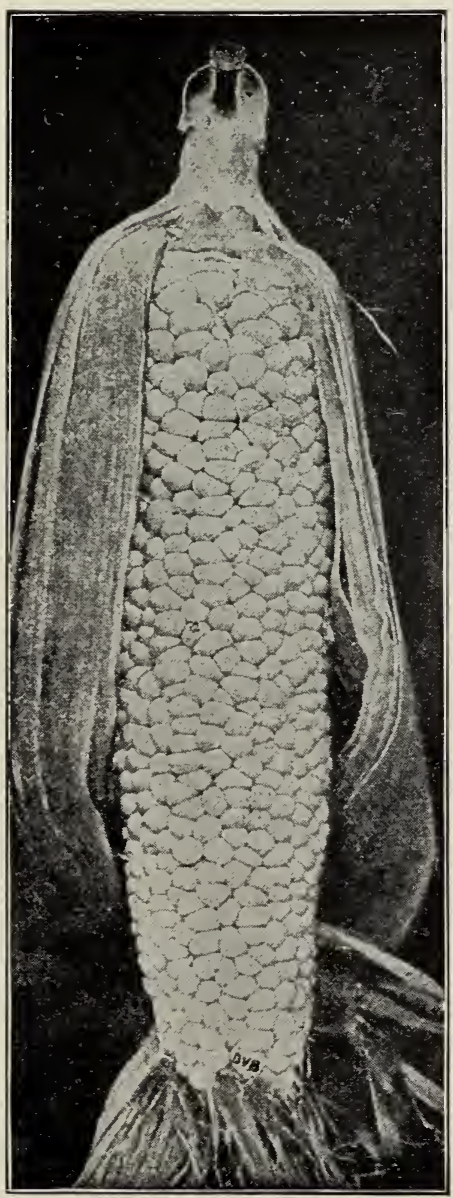

This variety produces long shoe peg kernels without rows. It is the sweetest of the sweet corns and no finer roasting ear is grown.

Having no rows it is an excellent sort to grow where worms bother the ears as instead of following a row into the center of the ear, thus spoiling it, they have no row to follow and instead work around the end of the ear, which can be cut off leaving the balance of the ear suitable for use.

Price: Pt., 15c; qt., 25c; pk., \$1.30; bu., $\$ 4.75$.

\section{Peep o’ Day}

This very early sort, five to ten days earlier than any other sort, is of great value to market gardeners who make most of their money by being the first in the market. In addition to its earliness, it is sweet and tender when cooked. It is distinct in habits of growth and appearance. Stalks grow about four feet high and the ears about five inches long, are well formed and filled out to the tips.

Pt., 10c; qt., 20c; pk., \$1.00; bu., \$3.25.

White Cory. A selection from the Red Cory, over which it is a great improvement. It is fully as early, and has white kernels and white cob. Pt., 10c; qt., 20c; pk., \$1.00; bu., \$3.25.

Early Minnesota. One of the standard varieties, of dwarf growth, a few days later than the Cory. Large kernels of fine quality. Pt., 10c; qt., 20c; pk., $\$ 1.00$; bu., \$3.25.

Mammoth White Cory. A very fine, large, early sort; ears double the size of the old Cory; the same pure white color when cooked, and having white cobs, thus giving fine appearance. Pt. 10c; qt., 20c; pk., \$1.00; bu., \$3.25.

Shaker's Early. Large ears of excellent quality. Follows Minnesota. A fine market sort. Produces very attractive ears with twelve to fourteen rows of pearly white grain. Pt., 10c; qt., 20c; pk., \$1.00; bu., \$3.25.

Early Mammoth. An early and smaller variety of the late Mammoth. Large ears, broad kernels; quality very good. Pt., 10c; qt., 20c; pk., \$1.00; bu., \$3.25.

Add $8 \mathrm{c}$ per pint, $15 \mathrm{c}$ per quart, if by mail. 


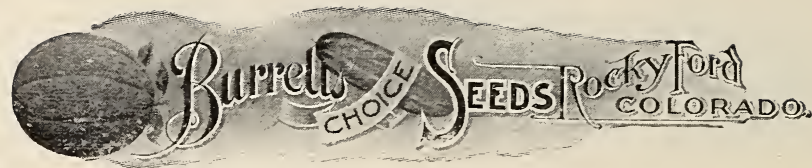

\section{Burrell's Select Stowell's Evergreen Sweet Corn}

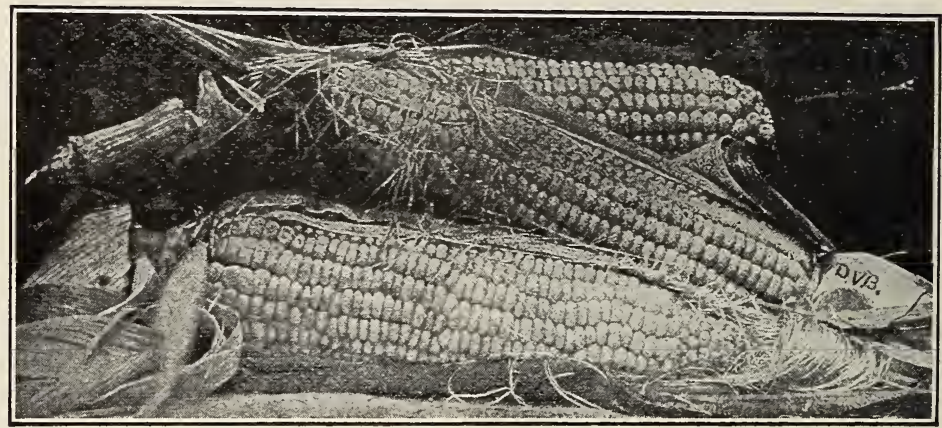

This is the leading standard variety for home use, market and canning. My stock is most carefully selected and can be depended upun to pruduct ist, large ears of superior quality. The stalks are of strong growth, each producing two large ears. The grains, while of good size, are long and slender, the cob being small. The grains are of rich, sugary flavor, and retain their fine quality until quite advanced. My stock is entirely free from glaze or flintness; the dried grains are much shriveled.

Pt., 10c; qt., 20c; pk., \$1.00; bu., \$3.75.

\section{EXTRA EARLY ADAMS.}

This is not a Sugar Corn, but is earlier. The ears are short, 12-rowed, and while in condition for roasting cannot be told from sugar corn. It will stand earlier planting than sweet corn and is a favorite wherever worms work badly on early corn.

Pt., 10c; qt., 15c; pk., 60c; bu., \$2.00.

\section{WHITE AUSTRALIAN.}

This is one of the most valuable sorts to grow where the nights are too cool for sweet corn or where worms bother the corn. The ears are long, eight to twelve inches, nearly all 8-rowed. The kernels are broad and white. While tender, it makes excellent roasting ears. If sweet corn does not do well for you, do not fail to try this sort.

Pt., 10c; qt., 20c; pk., \$1.00; bu., \$3.00.

\section{BLACK IMEXICAN.}

This is a very valuable sort for either early or late planting. In quality it is not excelled. Color when in roasting ear purple and white. This variety succeeds well in the Southwest especially. The ears are six to eight inches long and 8-rowed. The kernels are broad and of finest flavor.

Pt., 10c; qt., 20c; pk., \$1.00; bu., \$3.25.

\section{Pop Corn \\ QUEEN'S GOLDEN.}

This is the largest sort and produces abundantly. The grains are a rich golden color and are creamy white when popped, and a single kernel will expand to nearly an inch.

Pt., 10c; qt., 20c; pk., \$1.00; bn., \$3.00.

\section{WHITE RICE.}

A well-known variety. I offer a very fine strain which produces larger ears than usual and yields very heavy crops. The quality is excellent.

Pt., 10c; qt., 20c; pk., $\$ 1.00$; bu., $\$ 3.00$. 


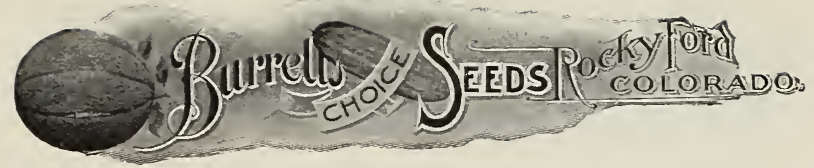

\section{Burrell's Special Gardener's Stock New York Improved Spineless Egg Plant}

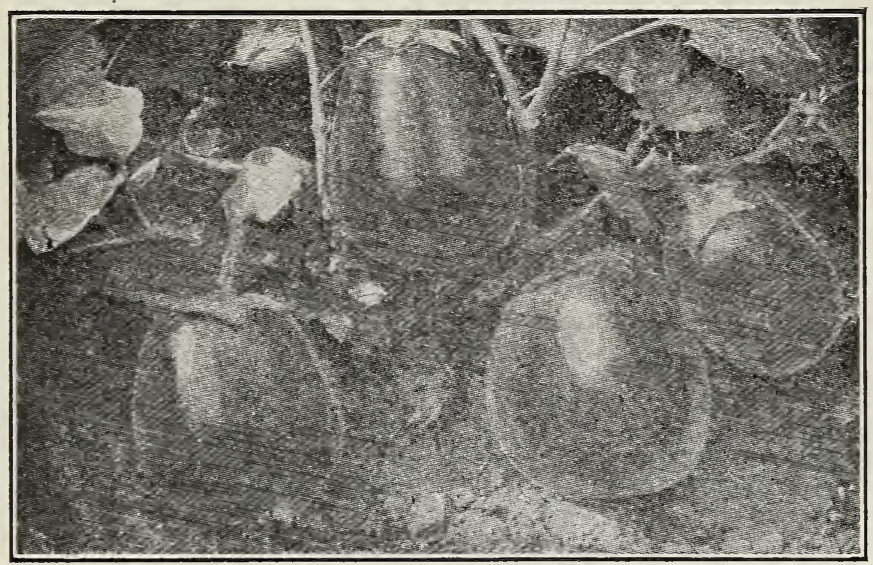

My seed of this, the finest variety of egg plant, has been selected for many years to a certain type until it is as fine as can be purchased from any source. The finest specimens from the most productive plants have been selected for stock seeds each year. The fruits are shaped as shown in cut and under favorable condition measure six to eight inches in diameter. The skin is a handsome, dark purple, flesh white, quality excellent. Market growers who plant largely will find this very desirable.

Pkt., 5c; oz., 25c; 1/4 lb., 90c; lb., \$3.20. Add 8c per pound if by mail.

\section{BLACK PEKIN EGG PLANT.}

The fruits of this variety are longer and darker colored than New York Spine. less, jet bla.ck, very glossy; a good sort.

Pkt., 10c; oz., 30c; 1/4 lb., \$1.00; lb., \$3.50. Add 8c per pound if by mail.

\section{Endive}

Add $8 \mathrm{c}$ per pound if by mail.

Green Curled Winter. The hardiest variety; leaves dark green, which readily blanch white. Not only most useful as salad, but much used for garnishing. Pkt., 5c; oz., 10c; $1 / 4$ lb., 30c.

White Curled. To be used when young for early spring. Pkt., 5c; oz., 10c; 1/4 lb., 30c. Add $8 \mathrm{c}$ per pound if by mail.

\section{Gourds}

Dipper. This is like the Sugar Trough; has a thin, hard shell, and can readily be made to serve useful purposes. Pkt., 5c; oz., 10c; 1/4 lb., 35c.

Japanese Nest Egg. Fruit small and creamy white; it exactly resembles the egg of a hen. Pkt., 5c; oz., 10c; 1/4 lb., 35c.

Sugar Trough. These gourds grow to hold from four to ten gallons; shells light, but very hard and durable, and readily made into useful household utensils. Pkt., 5c; oz., 10c; 1/4 lb., 35c.

Hercules Club. Longest of all. Pkt., 5c; oz., 10c; 1/4 lb., 35c.

Dish Cloth. Ornamental climber. The interior useful in kitchen when properly prepared. Pkt., 5c; oz., 10c; $1 / 4$ ib., 35c.

Mixed Sorts. This collection contains a great many varieties both useful and curious. Pkt., 5e; oz., 10c; 1/4 lb., 35c. 


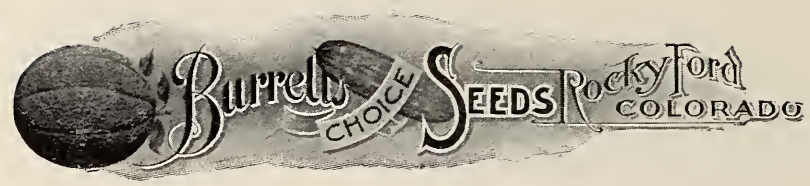

\section{Garlic}

Add 8c per pound if by mail.

Prepare the ground as for onions; plant bulb in early spring in drills, 12 inches apart, 4 inches in the row, 2 inches deep.

Bulbs: Lb., 15c; 10 lbs., \$1.25.

\section{Herbs, Sweet, Pot and Medical}

Anise. Has useful medicinal properties. Pkt., 5c; oz., 20c.

Balm. Used for balm tea or balm wine. Pkt., 5c; oz., 20c.

Basil, Sweet. Used for highly seasoned dishes. Pkt., 5c; oz., 20c.

Bene. Used in confectionery. Pkt., 5c.; oz., 20c.

Borage. Excellent for bees. Pkt., 5c; oz., 20c.

Castor Oil Plant. Pkt., 5c; oz., 15c.

Caraway. Used for flavoring. Pkt., 5c; oz., 20c.

Catnip. Used for seasoning. Pkt., 10c; oz., 50c.

Coriander. Useful culinary plant. Pkt., 5c; oz., 20c.

Cumin. Used for flavoring. Pkt., 5c; oz., 20c.

Dill.. Used to flavor pickles. Pkt., 5e; oz., 10c.

Fennel, Florence. Pkt., 5c; oz., 25c; 1/4 lb., 60c.

Henbane. Pkt., 5c; oz., 20c.

Hop Seed. Pkt., 25c; oz., \$1.50.

Horehound. For medicinal purposes. Pkt., 5c; oz., 30c.

Hyssop. For medicinal purposes. Pkt., 5e; oz., 20c; 1/4 lb., 60c.

Lavender. A popular aromatic herb, emitting a delightful perfume. Pkt., 5c; oz., $20 \mathrm{c} ; 1 / 4$ lb., 60c.

Marjoram, Sweet. Popular for seasoning. Pkt., 5c; oz., 20c; 1/4 lb., 50c.

Opium Poppy. Pkt., 5c; oz., 20c; 1/4 lb., 40c; lb, \$1.25.

Rosemary. An aromatic herb. Pkt., 5c; oz., 50c.

Saffron. Pkt., 5e; oz., 20c.

Sage. The leaves and tender tops are used in stuffing and in sauces. Pkt., 5c; oz., 20c; 1/4 lb., 50c; 1b., \$1.60.

Savory, Summer. Used for seasoning; also useful as a bee food. Pkt., 5c; oz., 30c; $1 / 4$ lb., 80c.

Tansy. Pkt., 5c; oz., 20c.

Winter Savory. Pkt., 5c; oz., 20c.

Wormwood, Pkt., 5e; oz., 35c.

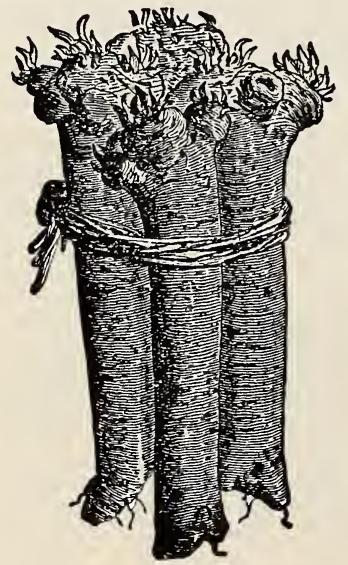

\section{Horse Radish}

Small Roots. Doz., 20c, postpaid; by freight or express, $100,50 \mathrm{c} ; 1,000, \$ 4.00$.

\section{Kale or Borecole}

Add $8 \mathrm{c}$ per pound if by mail.

Green Curled Scotch. Rarely exceeding 18 inches in height but spreading out under good cultivation to three feet in diameter. Leaves are beautifully curled and bright green. Pkt., 5c; oz., 10c; lb., 80c.

German Dwarf Purple. Is much esteemed by Germans; very compact and beautifully curled. Pkt., 5c; oz., 10c; lb., 80c.

\section{Kohl Rabi}

Early White Vienna. Best for general table use. Flesh tender and white. Extra fine in soup bunches. Pkt., 5c; oz., 20c.

\section{Leek}

Broad Scotch or London Flag. The hardy kind; large, strong plants with broad leaves.. Pkt., 5c; oz., 10c; 1/4 lb., 30c; lb., \$1.00.

Add 8c per pound if by mail. 

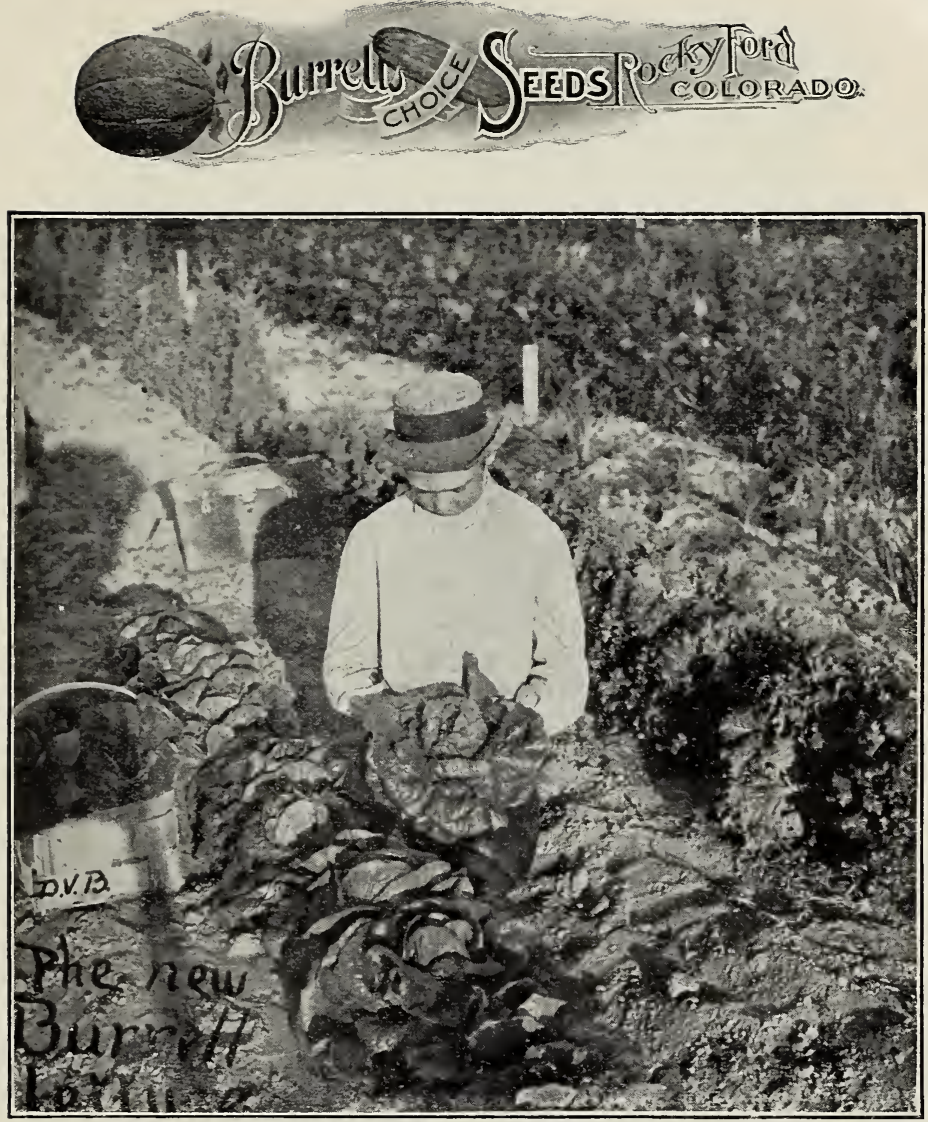

\section{The New Burrell Lettuce}

A great variety worthy of planting in every garden. Note in the lllustration the heads were very uniform and solid, almost like cabbage, when a large number of other varieties had "gone to seed," and many of the "long standing" varletles had passed the marketable stage. It comes up strong and grows rapidly. The outer leaves are bright green, curled and crinkled. The inner leaves blanched creamy white and all are very tender and of finest quallty.

Planted for Thanksglving and protected by brush and straw it will keep for a long time.

You will appreciate the value of this sort from the lllustration. Introduced in 1909 it pleased thousands of customers.

Price: Pkt., 10c; oz., 25c; 1/4 lb., 80c; lb., \$3.00.

As an ounce produces 8,000 to 10,000 plants the cost of this seed is very small considering its superior quality.

\section{Selected Market Gardeners' Big Boston Lettuce}

This is a very desirable varlety for forcing or outdoor culture. The heads are large and of fine qually. Planted very extensively South to ship North. Many of my customers purchase five to ten pounds each of this excellent varlety. Equally good for home or market garden.

Price: Pkt., 5c; oz., 10c; 1/4 lb., 30c; lb., \$1.00; 10 lbs. and up, 90c per lb.

\section{New Green Idyl}

This is a valuable new French sort quite simllar to the new Burrell Lettuce except that the heads are slightly looser and the seeds white Instead of black.

Proe:. Pkt., 50; 0z., 180; $1 / 4$ lb., 50c; lb., \$1.75. Add 8c per pound lf by mall. 


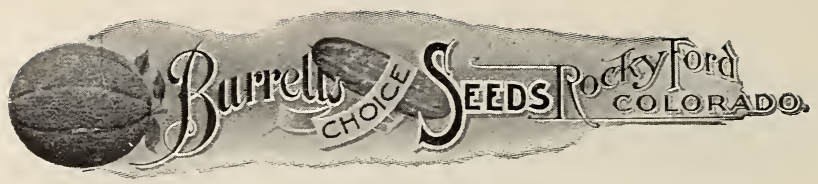

\title{
Lettuce--Continued
}

\author{
Add $8 \mathrm{c}$ per pound if by mall.
}

\section{CURLED OR LOOSE LEAVED SORTS.}

Grand Rapids Forcing. There is no better forcing variety among the curled leaved sorts than the Grand Rapids, and it is quite as good for outdoor culture as other sorts. Large, beautiful leaves, very crisp and tender. Twenty to thirty pounds have been raised from a common sash, and three crops taken off the ground. Frequently a house full of this lettuce will average one-half lonend to the plant, and occasionally a plant will weigh one and one-half pounds. Excellent for shipping, and will insure sales at sight. The soil cannot well be too rich. Pkt., 5c; oz., 10c; 1/4 lb., 20c; lb., 65c; 5 lb. lots, 60c per lb.

Black Seeded Simpson. The most popular sort of all the non-heading varietles. One of the best for use under glass as well as for early outdoor planting. The plants form large, loose heads; outer leaves a light, yellowish green, with inner leaves blanched almost white. Resists the heat and remains long in a good edible condition. For this reason it makes a popular variety for all market gardeners' use. Pkt., 5c; oz., 10c; 1/4 lb., 20c; lb., 65c; 5 lb. lots, 60c per lb.

Early Curled Simpson (Silesia). Forms a close, compact mass of leaves that are large and broad, crimped and blistered, and light green in color. Not desirable for forcing with bottom heat. It is, however, recommended for planting in cold frames, and extensively grown in the open. Pkt., 5c; oz., 10c; 1/4 1b., 20c; lb., 65c; 5 lb. lots, 60e per lb.

The New Morse. A careful selection from the Black-Seeded Simpson by a seed grower of large experience. Very desirable for growing under glass or out of doors. Style of growth resembles the Grand Rapids; leaves beautifully wrinkled and of brilliant green color. One of the best for spring and summer use. Quality the very best. Pkt., 5c; oz., 10c; 1/4 lb., 25c; lb., 70c; 5 lb. lots, 65e per lb.

\section{HEADING OR CABBAGE VARIETIES.}

Improved Hanson. This is a standard summer lettuce; none more reliable for outdoor cultivation. The heads grow to a remarkable size, and are very solid. The outer leaves are a bright green, while the inner head presents a white appearance, as though blanched; tender and crisp, and free from any unpleasant, bitter taste. It is very slow to seed, and is an ideal summer lettuce. Pkt., 5c; oz., 10c; 1/4 lb., $20 \mathrm{c} ; 1 \mathrm{lb} ., 65 \mathrm{c} ; 5 \mathrm{lb}$. lots, 60c per lb.

Salamander or Satisfaction. Forms large, solid, compact heads, resisting summer heat and remaining long in head. Leaves smooth, thick and very tender; the inner head blanching almost white. An excellent spring, summer or fall variety. Invaluable in the Southern states. Pkt., 5c; oz., 10c; 1/4 lb., 20c; lb., 65c; 5 lb. lots, 60c per lb.

Early Prize Head. This popular variety produces large, loose heads of finely crimped and fringed leaves, the outer portions of which are shaded with brown. Exceedingly crisp, sweet and tender. One of the best for the home garden. Pkt., 5c; oz., 10c; $1 / 4$ lb., 20; lb., 65c; 5 lb. lots, 60c per lb.

Denver Market Forcing. An early variety of head lettuce, either for forcing or open ground. It forms large heads of good, light green color, and is very slow to go to seed. The leaves are beautifully marked and blistered (like the Savoy Cabbage), very crisp and tender, and of excellent flavor.. Pkt., 5c; oz., 10c; 1/4 lb., $25 \mathrm{c} ;$ lb., 70c; 5 lb. lots, 65e per lb.

Marblehead Mammoth. This produces the largest head of any sort. The outer leaves are light green and the center leaves are white, and very crisp. Pkt., 5c; oz., 10c; 1/4 lb., 20c; lb., 65c; 5 lb. lots, 60c per lb.

"Trianon" Cos or Celery Lettuce. This lettuce excels all other sorts in quallty, having a crispness, tenderness and flavor peculiar to itself and not equalled by others. The heads are long and pointed. The outside leaves should be drawn over the top and tied, when they soon form solid heads and blanch quite white and become crisp and sweet as celery stalks. It may be eaten like celery or prepared as a salad. Pkt., 5c; oz., 10c; 1/4 1b., 20c; lb., 65c; 5 lb. lots, 600 por $1 \mathrm{~b}$. 


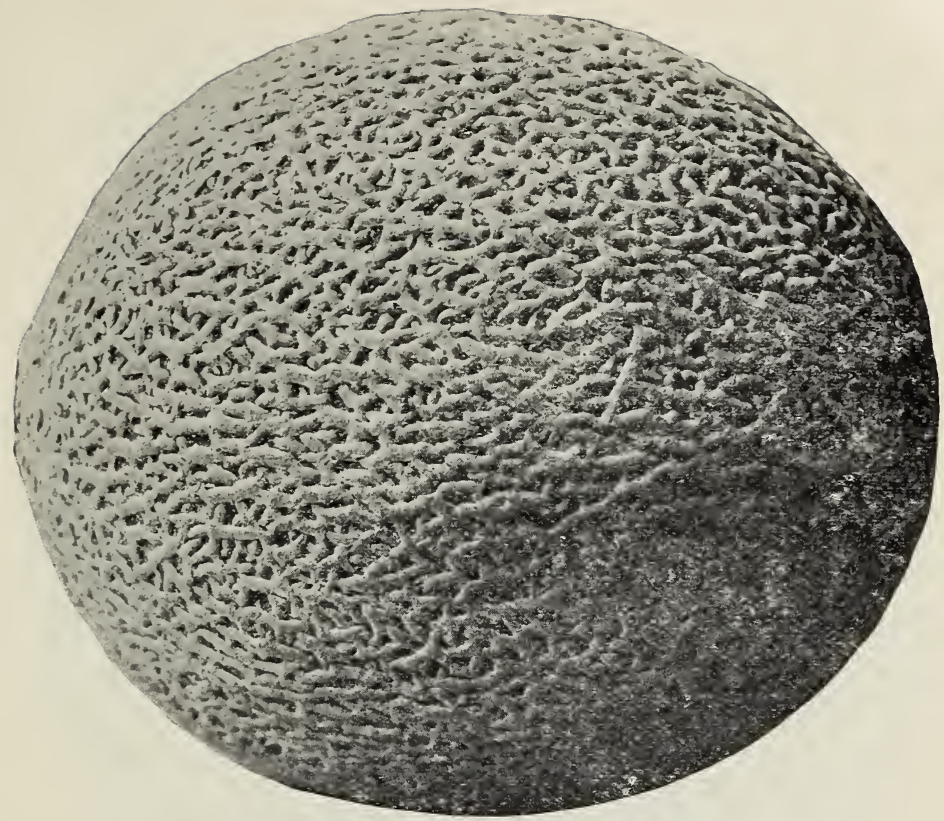

\section{Burrell's Select Rust-Resistant Rocky Ford Cantaloupe}

This is the highest development yet attained in the Rocky Ford Cantaloupe both in netting and rust-resistant qualities. The melons appear as shown in cut, solid net, the heavy gray netting being closely laced and interlaced over the entire surface of the melon from the stem to the well developed blossom button. The length and thickness as my crop run this year was ideal, fully 95 per cent of the melons being choice standard size.

The meat is light green and very deep; its flavor is not excelled by any of the green meat sorts and none of them are better, if as good, shippers.

It is highly rust resistant. Under favorable conditions when other strains rust badly the vines of this strain remain green and thrifty, continuing to blossom and set on fruits. The value owing to this quality is very great, as in many localities rust often destroys the crop, and when other strains have lost their quality on account of the rust this contilues to ripen melons of the highest quality.

It yields a heavy crop, continuing long in bearing and cannot fail to please. It is a week to ten days later than Burrell's Improved Extra Early Watters' and a few days later than Burrell's Thoroughbred Rocky Ford.

I recommend that this strain be planted exclusively if a green meated melon is desired, where rust injures the crop, and where there is not much danger of rust plant one-half to Burrell's Thoroughbred Rocky Ford or Burrell's Improved Extra Early Watters, and the other half to this strain. My seed is carefully selected, and none but the finest standard size, solid netted melons cut in this lot of seed. I have made the price as low as I can afford to offer this quality and hope to place some of the seed with every market grower who receives this catalog.

Large associations can tie to this variety, knowing nobody will have finer melons of the green meated strains.

Last year thousands of my customers planted this seed and report very satisfactory results. As an illustration, I saw a field of which one-half was planted with my seed of this variety and one-half of another strain of Rocky Fords. The vines of the latter strain died about two weeks after they began to bear, while the vines of my Rust-Resistant remained green, blooming and setting on fruits and maturing fruits of fine quality for four weeks after and until killed by frost. There was no difference in the cultivation and soil, being separated only the width of one row and planted, cultivated and watered at the same time

No matter how much you think of the strain you have been planting, plant this and compare results.

No. 1 Seed: Pkt., 5c; oz., 10c; $1 / 1$ lb., 30c; lb., $\$ 1.00 ; 10$ lbs. and up, $85 c$ per lb. Delivered by express.

Stock Seed: I offer such as I select to grow seed from-the finest possible selections, all ideal types. Pkt., 5c; oz., 15c; $1 / 4$ lb., 45c; lb., \$1.55; 10 lbs. and up, $\$ 1.50$ per 1b. Delivered by express. 


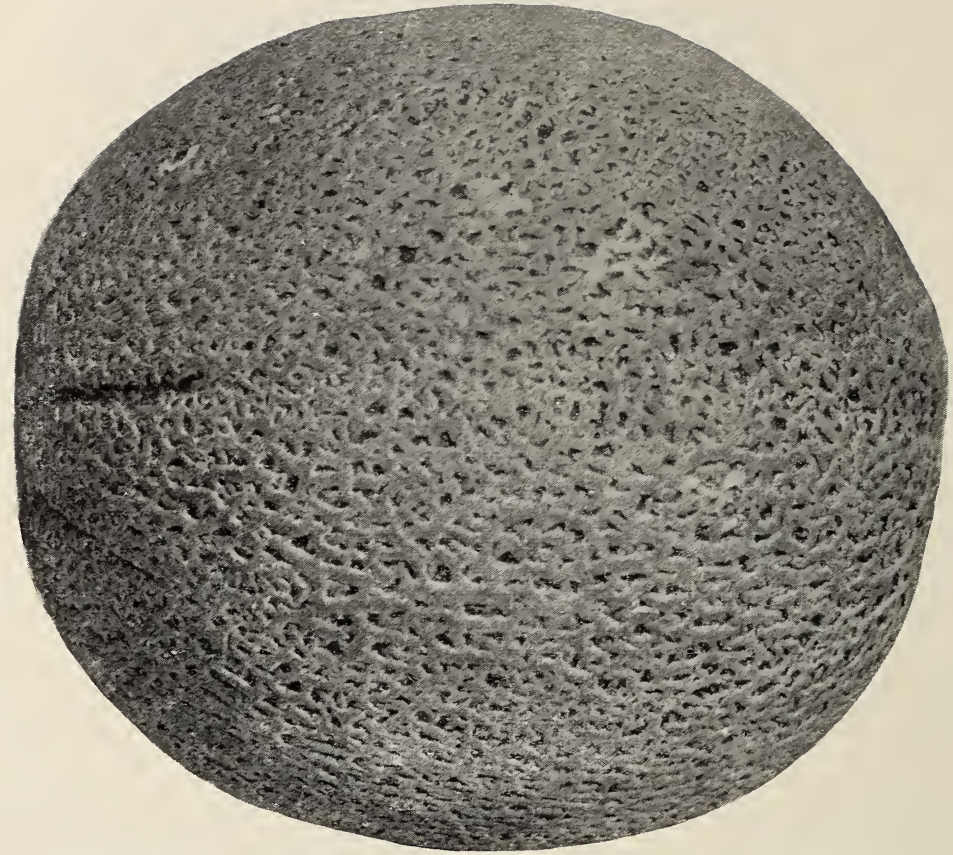

\section{Burrell's Select Eden Gem Cantaloupe Seed}

This strain of Rocky Ford Cantaloupe is favorably known in nearly all sections where Rocky Fords are grown. It is a heavy yielder, nearly all the melons are solid net, the cut above being a good illustration. The meat is deep and of excellent quality. The melons as grown here run standard size, there being but few too large and less too small. My trade amounts to several thousand pounds of this seed annually.

Stock Seed. From ideal specimens, the finest possible selection. Pkt., 5c; oz., $15 \mathrm{c} ; 1 / 4 \mathrm{lb}$., 45c; $1 \mathrm{~b} ., \$ 1.55 ; 10$ lbs. and up, $\$ 1.50$ per lb. Express prepaid.

No. 1 Seed. Cut from standard, well netted seed melons of very desirable quality, such as should be planted by market growers' associations and extensive market gardeners who appreciate the fact that good seed is necessary to produce good crops.

The price I make you is made possible only by the very extensive acreage which I grow for seed ( 400 acres of cantaloupes exclusively for seed), and the very best arrangements which $I$ have for caring for the seed.

Price:. Pkt., 5c; oz., 10c; $1 / 4 \mathrm{lb} ., 30 \mathrm{c} ; \mathrm{lb}$., $\$ 1.00 ; 10$ lbs. and up, 85e per lb. Delivered by express.

No. 2 Seed. Saved from the fields grown for market from melons too ripe to ship when picked. I recommend the No. 1 seed as the best to plant, but this seed is much more desirable than ordinary seed offered at about this price. I know the fields it comes from and the class of melons cut. express.

Price: Oz., 5c; 1/4 lb., 15c; lb., 50c; $10 \mathrm{lbs}$. and up, 40c per lb. Delivered by

\section{Hoodoo}

This new musk melon is of recent introduction. The melon is the same size through from top to bottom as the Rocky Ford Cantaloupe. It is slightly flattened from stem to blossom end. The netting is well developed and covers the ribs completely. The space between the ribs is not netted, but is quite narrow. The rind is tough. Meat salmon colored and grained the same as the Rocky Ford Cantaloupe. The flavor is pleasant. I recommend it as a valuable sort. I do not know whether it will crack if grown under rainfall, but believe it will pay you to try it. My seed is my own growing from the introducer's stock and can be depended upon. No better can be bought.

Price: Pkt., 5e; oz., 15e; 1/4 lb., 40c; lb., \$1.50. 

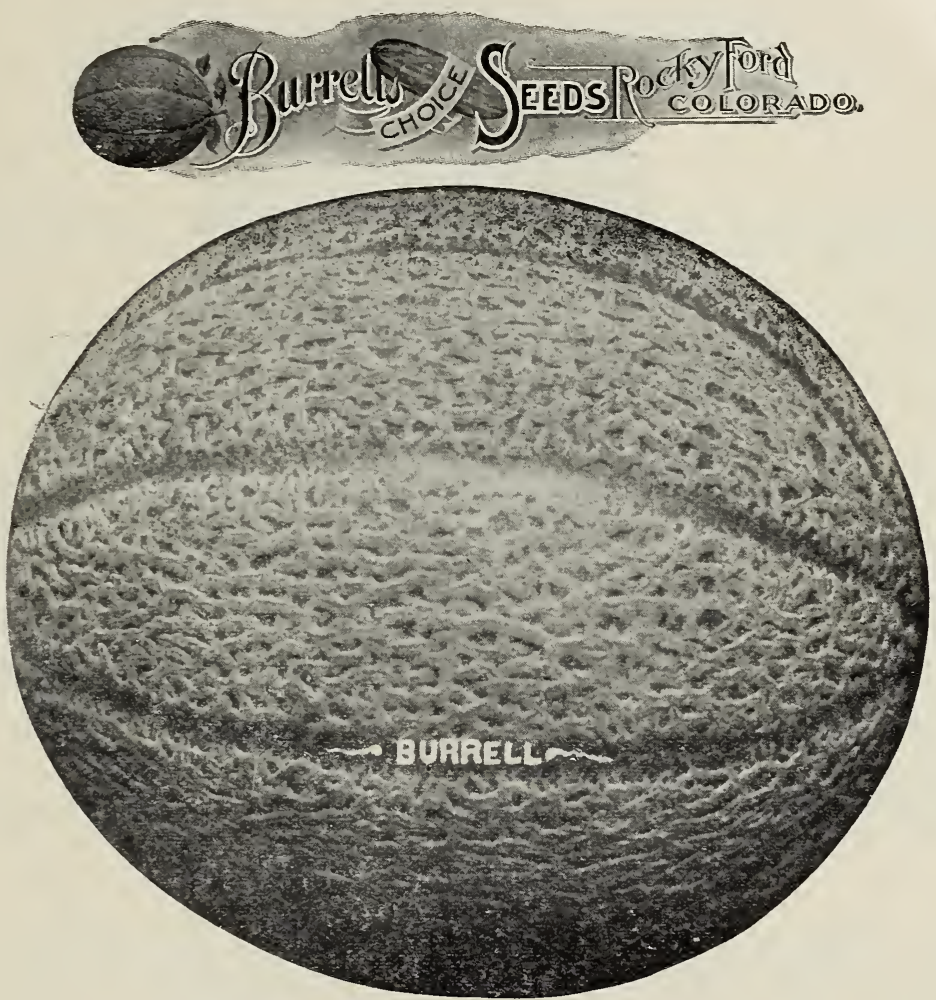

\section{Burrell's Thoroughbred Rocky Ford Cantaloupe}

This famous melon was first offered to planters by myself nine years ago and has rapidly grown in favor until at the present time my orders amount to some ten thousand pounds a year. Last year I was sold out early and had to refuse orders for several thousand pounds. I had to wire hundreds of large customers that I was sold out of this seed and tell them what I could supply, asking them to wire advice at my expense. I have made an extra effort to be able to supply all this year.

The photograph shown above is my ideal.

This melon has ten distinct ribs covered with a closely laced and interlaced gray netting. The space between the netting is light green, changing to a pale slate green when ready to pick. The space between the ribs is very narrow and does not in any way weaken the melon. There is a slight tendency to net across this space, but about 90 per cent have the space well defined from stem to blossom button. The blossom end is well protected by a small button. The flesh is light green, changing very slightly toward yellow at the center. Seed cavity small. The size is very uniform. Grown here, about 90 per cent of the melons run standard size.

It is an excellent market sort. I offer the seed in two grades, as follows, sold only in sealed packages:

Stock Seed Burrell's Thoroughbred Rocky Ford Cantaloupe.

This is the finest possible selection, such as I grow seed from.

Price: Pkt., 5c; oz., 15c; 1/4 lb., 45c; lb., \$1.55; $10 \mathrm{lbs}$. and up, \$1.50 per lb.

No. 1 Seed Burrell's Thoroughbred Rocky Ford Cantaloupe.

This is cut from choice melons grown exclusively for seed. No melons shipped from the field. It is planted extensively by associations and other large planters. It gives excellent results.

Price: Pkt., 5c; oz., 10c; 1/4 lb., 30c; lb., \$1.00; 10 lbs., \$9.30; 20 lbs., \$18.00; 40 lbs. and up, 85c per lb.

I make a specialty of growing under contract for extensive Southern planters and associations any variety you want from the finest stock seeds obtainable. If you use large lots of seed let me know what you want and I will make you growing price with earnest endeavor to get your business, but will not quote a low price at expense of quality. Remember, it's "quality first." 


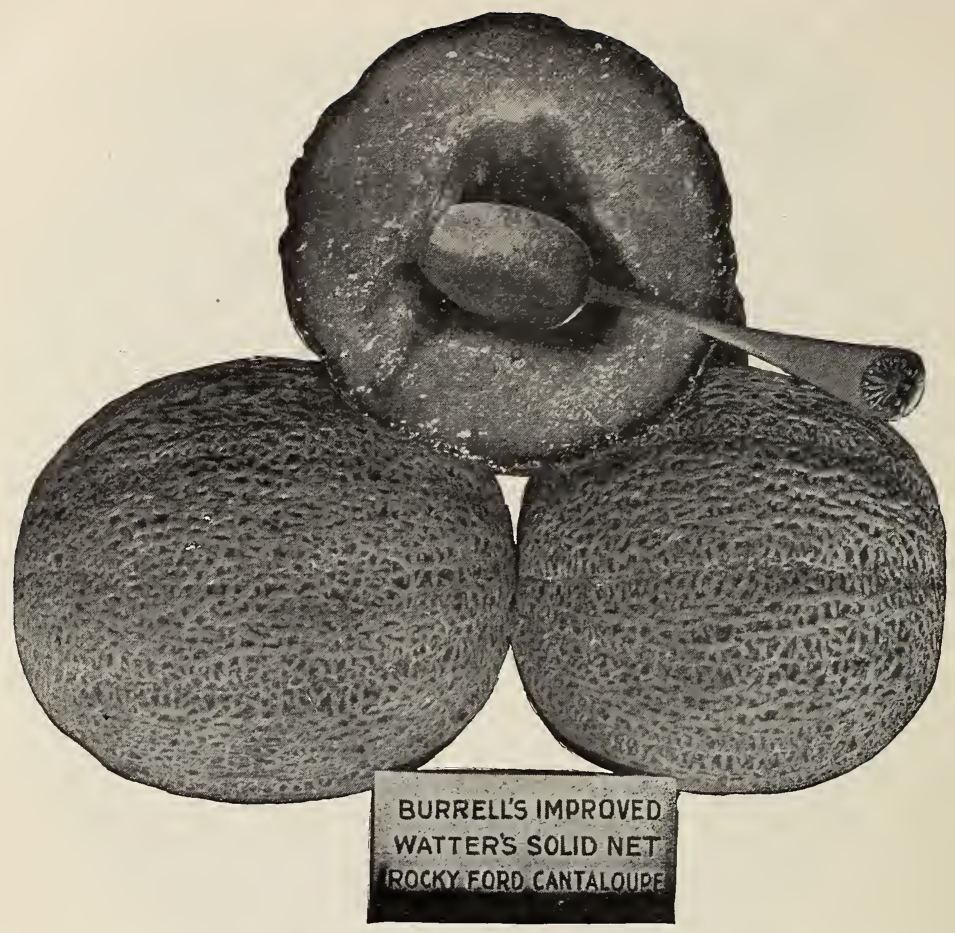

\section{Burrell's Improved Watters' Solid Net Rocky Ford Cantaloupe}

EXTRA EARLY.

This SOLID NET Cantaloupe is the earliest strain of Rocky Ford Cantaloupes. It sets a very heavy first crop se that in a few days after the first crop begins to ripen large pickings are getting ripe. The netting is well developed, gray, and closely laced. The flesh is light green and of excellent quality. The seed cavity is some larger than either of the previous strains listed.

I have sold large quantities of this seed to market growers, with uniformly good results. My fields of this were very fine and produced a large crop of the finest melons.

No. 1 Seed. Grown from the finest selection of stock seeds and cut from none but standard, well-netted and fully developed melons from my own flelds grown exclusively for seed.

Pkt., 5c; oz., 10c; 1/4 lb., 30c; lb., \$1.00; 10 lbs. and up, 85c per lb. Delivered by express.

\section{STOCK SEED.}

I have about 1,000 pounds of this seed selected from ideal specimens, the finest possible selection, which I offer at:

Pkt., 5c; oz., 15c; 1/4 lb., 45c; 1b., \$1.55; 10 lbs. and up, \$1.50 per lb. Delivered by express.

This is the grade of seed which I select to grow seed from. While I recommend my No. 1 seed as being very dependable, such as has pleased thousands of market growers, there are many who want this extreme care in selection. Will also supply as long as my stock lasts Stock Seed Fden Gem, Stock Seed Burrell's Select RustResistant Rocky Ford Cantaloupe and Stock Seed Burrell's Thoroughbred Rocky Ford Centaloupe. 


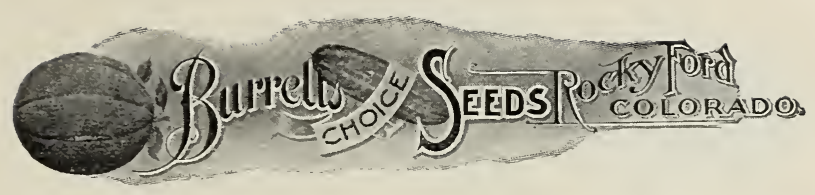

I first introduced this now famous melon on the market in 1904, marketing 41 baskets. In 1905 , I grew 12 acres for market and sold $\$ 6,000.00$ worth of melons from this tract. In 1906 I placed them on the Chicago and New York City markets where they at once grew into great favor, selling for two to three times as much as any other melon, which they also repeated each year since.

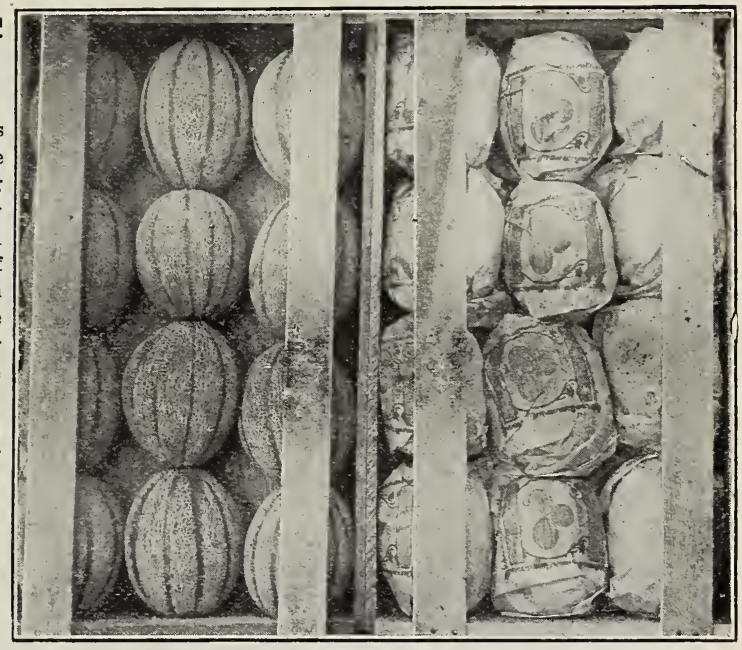

\section{The Burrell Gem Cantaloupe}

The illustration above shows a crate before wrapping the melons and a wrapped crate ready for market. The crate I am now using for the standard melons measures 24 inches long, $13 \frac{1}{2}$ inches wide, $4 \frac{1 / 2}{2}$ inches deep, and holds 12 melons or 15 smaller sized melons. About 80 per cent of my melons run 12 to the crate. The small melons, 15 to the crate, do not sell as well and it is quite an advantage to get as many 12 's as possible.

This is an abundant ylelder, often producing 15 to 25 melons to the hill. The meat is rich golden color, very thick, and fine grained. The flavor cannot be excelled. The seeds are closely held in place in three lobes and do not easily shake loose. The rind is covered with a closely laced gray netting, except the narrow stripe between the ribs, which is not netted. The blossom end is well protected. Shape oblong, averaging six inches long and tapering at the ends. It is an excellent shipper and will carry nearly two weeks without ice.

I do not recommend it for planting where there is excessive rainfall as this will cause them to crack.

\section{STOCK SEED BURRELL GEM-The Finest Possible Selection.}

Price: Pkt., 5c; oz., 15c; 1/4 lb., 50c; lb., \$1.75; 10 lbs. and up, \$1.50 per lb.

No. 1 Seed Burrell Gem, saved from fine, well-netted melons. I recommend this seed to market growers as being very desirable. This melon has brought hundreds of growers profitable returns. It will pay you to give it a trial, for if it is adapted to your soil and climate, you will be well paid for your efforts.

Price: Pkt., 5c; oz., 10c; 1/4 lb., 30c; lb., \$1.00; 10 lbs. and up, 85c per lb, Above prices are delivered by express. 


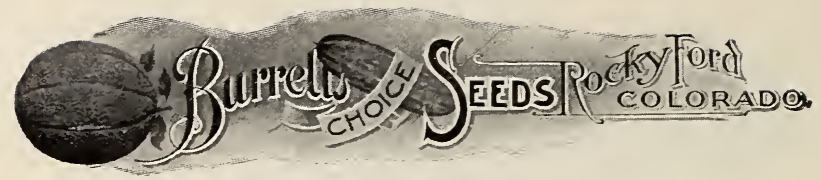

\section{Muskmelons}

\section{ALL MUSKMELON CROPS ARE VERY SHORT.}

Emerald Gem. This extra fine variety is worthy of special mention and has but few equals for the home garden, but being without netting and often cracking open when ripe, it is not a good market melon. Medium size, perfectly smooth; skin a deep emerald green with white ribs. Very attractive in appearance. Flesh salmon colored, very deep, and quality almost equal to the Rocky Ford. Do not fail to grow a few. Pkt., 5c; oz., 15c; 1/4 lb., 40c; lb., \$1.50.

Improved Yellow Cantaloupe. Round, flesh reddish orange; skin netted and yellow when ripe. Pkt., 5c; oz., 10c; 1/4 Ib., 30c; lb., \$1.00.

Paul Rose. This is a very good melon, has few equals for home garden and is a fair shipper. Fruit oval. Flesh a rich orange red. Mr. Paul Rose, who introduced this melon, has made himself famous in the produce world, and the large acreage which he grows each year finds a ready market. Pkt., 5c; oz., 10c; 1/4 lb., 30c; lb., \$1.00.

Extra Early Hackensack. An improvement on the old well-known Hackensack. Same quality, ten days earlier. Pkt., 5c; oz., 10c; $1 / 4$ 1b., 30c; lb., \$1.00.

Superior. This variety is highly esteemed. The fruits are of medium size, without ribs, and heavily netted. Flesh light green, excellent quality. Pkt., 5c; oz., 10c; $1 / 4$ lb., 30c; lb., \$1.00.

Osage. This is a very popular melon and one of the best, owing to its fine spicy flavor and good shipping qualities. Skin dark green, slightly netted; flesh salmon color. Very productive, and a long keeper. Pkt. 5c; oz. 10c; 1/4 lb. 30c; lb. \$1.00.

Bay View. Early, vigorous, productive, often weighs 12 to 15 pounds; flesh green and of good flavor; shape long. Pkt., 5c; oz., 10c; 1/4 1b., 30c; lb., \$1.00.

Chicago Market. Large, green-fleshed nutmeg of good quality; round and flattened. A favorite in Chicago. Pkt., 5c; oz., 10c; $1 / 4$ lb., 30c; lb., $\$ 1.00$.

Acme or Baltimore Market. This is a favorite in the Baltimore market and is well known at other large markets. Early, oblong in shape; flesh green and very fine. Pkt., 5c; oz., 10c; 1/4 lb., 30c; lb., \$1.00.

Tip Top. This variety has a light, slate-colored rind; fruits are nearly round, deeply ribbed; the flesh is deep and salmon-colored; very fine grained and of desirable flavor. It is a good variety to grow for nearby markets. Pkt., 5c; oz., 15e; $1 / 4$ lb., 40c; lb., \$1.50.

Cu Cu Improved Banana. This is a very fine melon for the home garden or nearby markets; the shape is long, 15 to 18 inches, 4 to 6 inches thick and tapering toward both ends. The quality is equal to the finest Banana Muskmelon and better than the average. Pkt., 5c; oz., 10c; 1/4 lb., 30c; lb., \$1.00.

In addition to the above varieties $I$ offer:

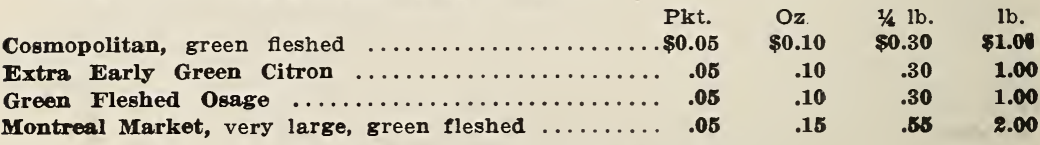



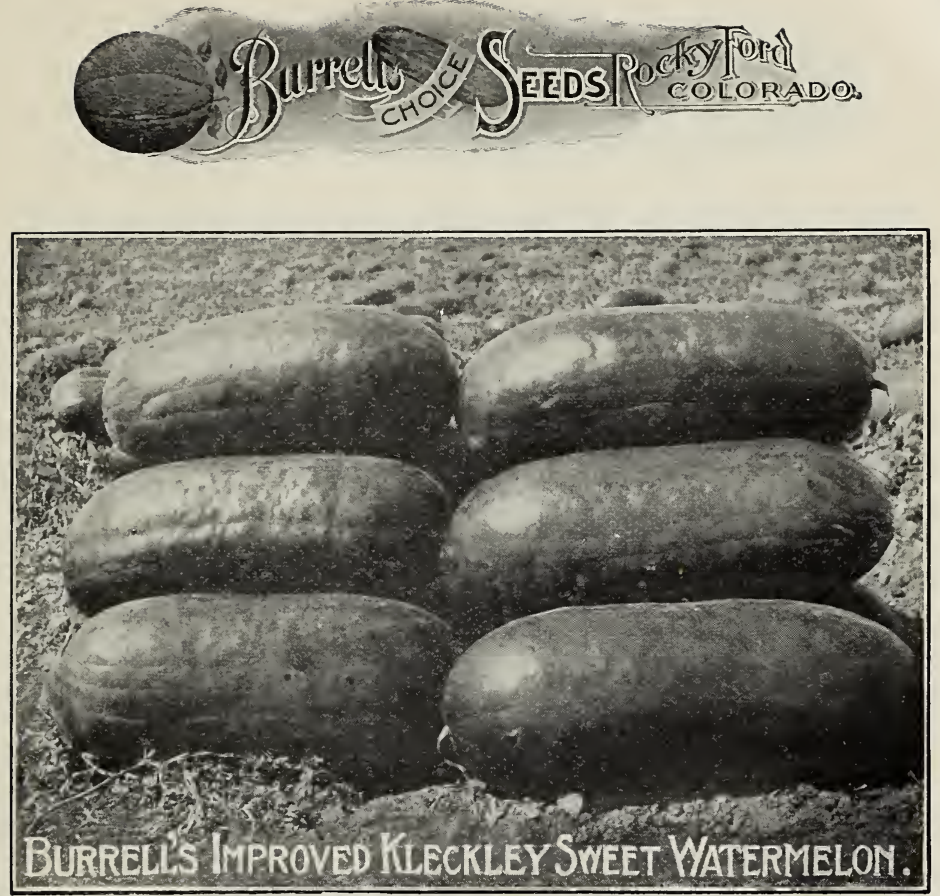

My strain of this melon is listed by some as the New Hard Shell Kleckley Sweet.

\section{The Most Delicious Watermelon Grown, Very Productive and of Attractive Appearance.}

Again I offer this strain as the finest eating melon and the thousands of customers who continue to plant it speak volumes in its favor. Some report sales of as much as $\$ 200.00$ to $\$ 250.00$ per acre, which surely is very good As it grows with me it is not only the best eating melon, but a good shipper which holds first place on many markets.

The melon is oblong, ends square, color dark green, flesh deep red, stringless, solid and very sweet with but few white seeds set firmly near the rind.

\section{Stock Seed Burrell's Improved Kleckley Sweet Watermelon.}

See long row of melons on back cover. This seed was cut from just such melons as are in this row, also such melons as are pictured in the pile above. The stock seed melons would average 35 pounds each. I know the supply of this seed will not go around. While it lasts the price is: Pkt., 5c; oz., 15c; 1/4 lb., 55e; Ib., \$2.00. Not over five pounds to one purchaser. If it is sold out when your order comes I will promptly refund your money. this.

When you order above seed, in case you want No. 1 , if stock is sold out, mention

No. 1 Seed Burrell's Improved Kleckley Sweet Watermelon. Saved from desirable melons grown from same stock seed as above: Pkt., be; oz., 10c; 1/4 lb., 35c; lb., $\$ 1.25 ; 10$ lbs. and up, $\$ 1.10$ per $1 b$.

\section{About Watermelons.}

Watermelons are lovers of drouth and succeed best in a well-drained sandy loam. Never plant watermelons where they have been grown before unless it be eight or ten years later, and not even then unless the land has been seeded to clover, alfalfa or a similar crop. The vines remove some element from the soil that is not supplied to the second crop and the result is poor melons with black ends and of very undesirable quality. Plant them on new land, cultivate well: do not give any weeds a chance to grow; leave only one plant to the hill and hills elght to ten feet apart each way. Plant Burrell's best seed ten to twelve to the hill, and thin to one when they have six to eight leaves. Many report returns of from $\$ 100$ to $\$ 300$ per acre from watermelons grown from my seeds. 
34
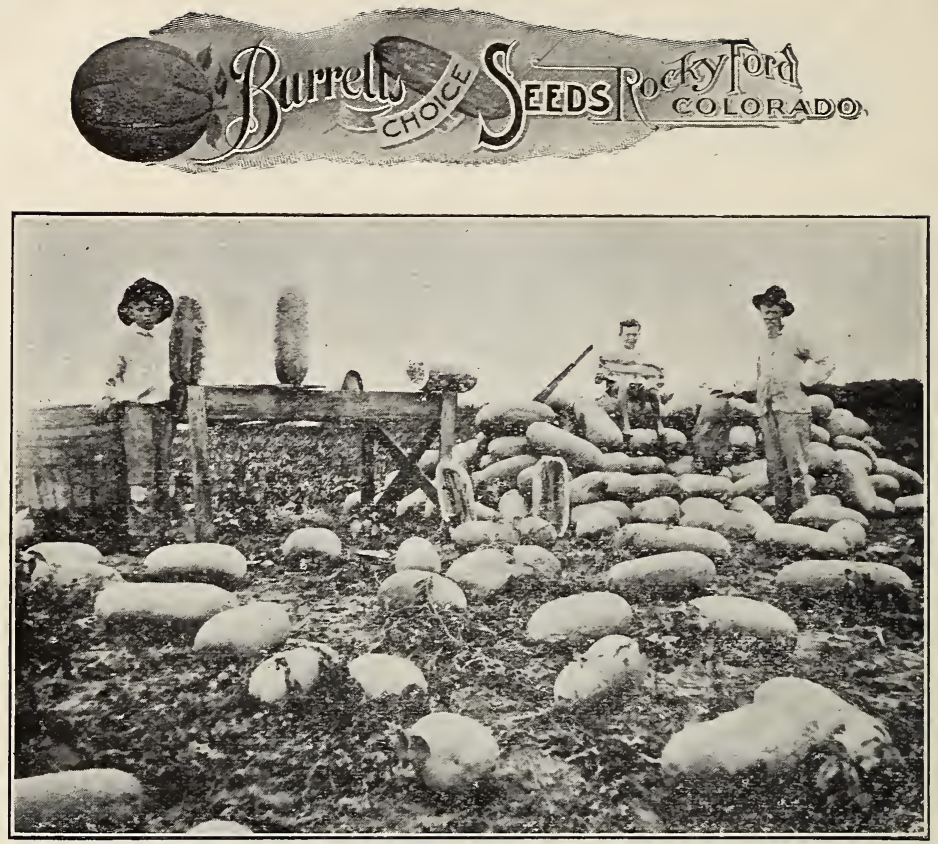

\section{Burrell's Select Alabama Sweet Watermelon}

A number of my customers have requested me to select this seed only from the largest melons, cutting off the ends and saving the seed only from the middles. It is my business to produce the seeds as my customer want them, and for this year I grew and selected 500 pounds in this way.

This is a fine shipper. My seeds are planted extensively by many of the most successful Texas and other Southern melon growers.

The rind is dark green marked with still deeper green mottled stripe and while thin it is very tough, making the melon a first-class shipper. The flesh is bright red, fine grained, sweet and luscious, entirely stringless and very firm. The seeds are white slightly tipped. with brown, and are firmly set in small cavities near the rind.

In ordering this seed call for Stock Seed Burrell's Select Alabama Sweet Watermelon. Price: Pkt., 5c; oz., 15c; 1/4 lb., 55c; lb., \$2.00. Not over 5 lbs. to one customer.

No. 1 Seed, Burrell's Select Alabama Sweet Watermelon. Southern grown from the same stock seed as above. No melons shipped from the field. Cut in one grade and only good melons cut. Pkt., 5c; oz., 10c; 1/4 lb., 25c; lb., 75c; 10 lbs. and up, $60 \mathrm{c}$ per $1 \mathrm{~b}$.

\section{The New Tom Watson Watermelon}

This large dark green watermelon, often weighing 50 to 60 pounds and averging on good soil over 30 pounds, has in two years taken place among the first. The flesh is deep red and contains very few seeds firmly bedded; is a good shipper and yields a heavy crop. My seed is grown especially for me in the district in the South where it originated, and is of the best to be had. There will be a large demand and your orders should be sent in early. Pkt., 5c; oz., 10c; 1/4 1b., 30c; lb., $\$ 1.00 ; 10$ lbs. and up, 85e per $1 \mathrm{~b}$.

\section{Halbert Honey Watermelon}

This melon is the same color and shape of my Improved Kleckley Sweet, but is more tender. The melons split ahead of the knife when cut. The seeds instead of belng white are a rather dull white with slight brown tips.

It is of excellent quality and will be ordered extensively by those who know it best, which is the best recommendation that a melon can have.

Price: Pkt., 5c; 0x., 10c; 1/4 lb., 80c; lb., \$1.00; $10 \mathrm{lbs,} \mathrm{and} \mathrm{up,} 850$ per lb. 


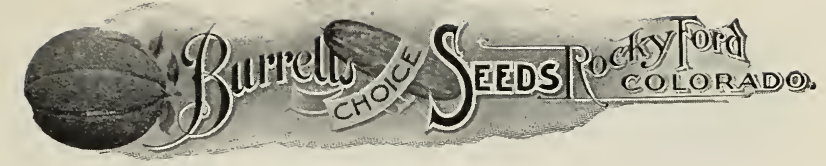

\section{The New Eden Watermelon}

This melon was originated by one of the leading melon growers in South Carolina and is an excellent shipper. The outer rind is colored, as shown in cut, being marked with light and dark green. The seeds are white and set in small cavities, and the flesh is quite firm and red. It has a very tough rind and is one of the best shippers. Pkt., 5c; oz., 10c; 1/4 lb., 20c; lb., 65e; 10 lbs., $\$ 6.00$; 50 lbs. and up, 55c per $1 b$.

Girardeau's Triumph. This is an excellent shipping sort. It is early, the melons are large, dark green with indistinct stripes. The flesh is solid and sweet. Pkt., 5c; oz., 10c; 1/4 lb., 20c; lb., 65c; 10 lbs., $\$ 6.00$; 25 lbs. and up, 55c per $1 b$.

Florida Favorite. A beautiful melon with light and dark green exterior. Shape oblong; flesh bright crimson, crisp and deliciously sweet. It is only a few days later than

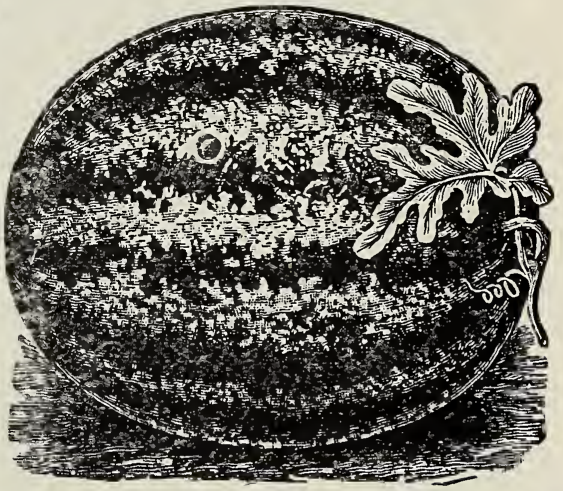
the first early sorts, and a good shipper. Pkt., 5c; oz., 10c; 1/4 lb., 20c; lb., 65c; 10 lbs., $\$ 6.00$; 25 lbs. and up, 55c per lb.

Carolina Bradford. This is a large, long, dark green melon, dimly marked with lighter green stripes. The rind is tough, making it a good shipper. Pkt., 5c; oz., 10c; 1/4 lb., 20c; lb., 65c; $10 \mathrm{lbs}$., $\$ 6.00$; 25 lbs. and up, 55c per lb.

Black Spanish. Round, dark green, scarlet flesh, black seeds; not a large melon, but of good flavor. Pkt., 5c; oz., 10c; 1/4 lb., 20c; lb., 65c; 10 lbs., \$6.00; $251 b s$. and up, 55c per lb.

Georgia Rattlesnake. An excellent market variety; large, oblong; rind dark, mottled and striped; a well-known shipping melon. Pkt., 5c; oz., 10c; 1/4 lb., 20c; lb., 65c; 10 lbs., \$6.00; 25 lbs. and up, 55c per lb.

Early Fordhook. A very popular sort; medium size; flesh red and sweet; color a mottled gray. Pkt., 5c; oz., 10c; 1/4 lb., 20c; lb., 65c; 10 lbs., \$6.00; 25 lbs. and up, 55c per lb.

Gray Monarch. One of the largest melons, often weighing 60 to 70 pounds. Rind mottled gray; shape long; flesh crimson, of a good flavor; and a good shipper. Pkt., 5c; oz., 10c; $1 / 4$ lb., 20c; lb., 65c; 10 lbs., $\$ 6.00 ; 25$ lbs. and up, 55c per lb.

MeIver's Wonderful Sugar. This is a very hardy grower; usually about 2 feet long and 10 to 12 inches in diameter; color dark green, striped with light green; of fine appearance and extra quality. Pkt., 5c; oz., 10c; 1/4 lb., 20c; lb., 65c; 10 lbs., $\$ 6.00 ; 25$ lbs. and up, 55c per lb.

Phinney's Early. Another very early melon; hardy; a sure cropper; extensively cultivated in the North. Pkt., 5c; oz., 10c; $1 / 4$ lb., 20c; lb., 65c; 10 lbs., \$6.00; 25 lbs. and up, 55e per lb.

Mountain Sprout. Large, long, dark green, marbled with lighter shades. Pkt., 50; oz., 10c; 1/4 lb., 20c; lb., 65c; 10 lbs., $\$ 6.00 ; 25$ lbs. and up, 55c per lb.

Cole's Early. This is one of the earliest melons and a very hardy, sure cropper; medium size, slightly oblong shaped; rind green, striped with lighter shades; flesh dark red. Pkt., 5c; oz., 10c; 1/4 lb., 20c; lb., 65c; 10 lbs., \$6.00; 25 lbs. and up, 55c per lb.

Dixie. One of the best. A cross between the Kolb's Gem and Mountain Sweet, possessing the best qualities of both. Rind dark green, striped with light green; shape much longer than Kolb's Gem; very large and of good flavor. Pkt., 5c; oz., 10c; $1 / 4$ lb., 20c; lb., 65e; 10 lbs., \$6.00; 25 lbs. and up, 55c per lb.

Ice Cream. An early variety of good flavor. One of the best to grow in the North, and being so good, it is one that should be in every garden. Pkt., 5c; oz., 10c; $1 / 4$ lb,. 20c; lb., 65c; 10 lbs., $\$ 6.00 ; 25$ lbs. and up, 55c per lb.

Kentucky Wonder. A new red-seeded variety; oblong; rind dark green with lighter stripes. Flesh a bright red, sugary and firm; it is never mealy. Very good. Pkt., 5c; oz., 10c; $1 / 4$ lb., 20c; lb., 65c; $10 \mathrm{lbs} ., \$ 6.00 ; 25$ lbs. and up, 55e per lb.

Kolb's Gem. More largely grown in the South than any other melon. An extra shipper; round, large, good quality; color dark green, mottled. Pkt., 5e; oz., 10e; $1 / 4$ lb., 20e; lb., 65e; 10 lbs., $\$ 6.00$; 25 lbs. and up, 5be per lb. 


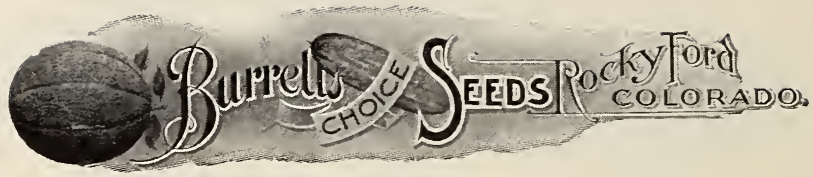

\section{Select New Chilian Watermelon}

This is the favorite melon in California and especially in the southern part, where large profits are made growing it.

My strain of this melon produces all white seeds. Some others produce mixed white and pale red seeds. Extreme care has been taken to make my strain the best possible and my crop the past year was as fine as could be desired.

The rind is thin and tough. The white seeds are set near the rind; heart bright red, stringless and of excellent quality.

Price: Pkt., 5c; oz., 10c; 1/4 lb., 20c; lb., 75c; 10 lbs., \$7.00; 40 lbs. and up, 60c per lb.; delivered by express.

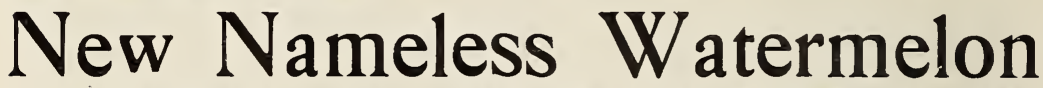

This melon has a very light colored rind which is the thinnest of all Watermelons, many having less than one-quarter inch thickness of rind. The flesh is rich red. The heart large and stringless. The seeds are very small, being less than half the size of ordinary Watermelons. About 90 per cent of the melons are nearly round, the remaining being rather long, so that $\mathrm{I}$ am now selecting to be able to offer two types, Round and Long. Don't fail to try this melon for your home garden. It will not ship as the rind cracks too easily. Pkt., 10c; oz., 50c.

In addition $I$ offer the following varieties at the uniform price of: Pkt., 5c; oz., 10c; $1 / 4$ lb., 20c; lb., 65c; 10 lbs., $\$ 6.00 ; 25$ lbs. and up, 55e per lb. Black Diamond, Boss, Duke Jones, Light Icing, Sweetheart, and Vick's Early.

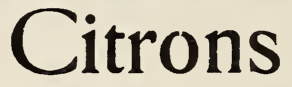

Add 8c per pound if by mail.

Green Seeded Colorado. Fruit round; an improved variety. Pkt., 5c; oz., 10c; 1/4 lb., $20 \mathrm{c} ; \mathrm{lb.}, 65 \mathrm{c} ; 10$ lbs., $\$ 6.00$; 25 lbs. and up, 55c per lb.

Red Seeded Citron. The old variety; good quality. Pkt., 5c; oz., 10c; 1/4 lb., 20c; lb., 65c; 10 lbs., $\$ 6.00$; 25 lbs. and up, 55c per lb.

\section{Pomegranate}

Add 8c per pound if by mail.

An ornamental little fruit which a century ago was commonly grown in the gardens, but is now rarely seen. Grows on a pretty vine. Fruit is round, of a bright yellow, irregularly striped with orange red or mahogany; very fragrant; a single specimen will sweetly perfume a room for many days. Prolific and easily grown. It is often called Queen Anne's Pocket Melon. Pkt., 5c; oz., 15c; 1/4 1b., 40c.

Add $8 \mathrm{c}$ per pound if by mail.

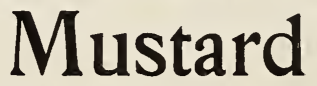

Add $8 \mathrm{c}$ per pound if by mail.

White English. The leaves are light green, mild and tender when young; seed light yellow. Oz., 5c; 1/4 lb., 10c; lb., 35c; 10 lbs., $\$ 3.00$.

Brown. Stronger and more pungent than the above. Oz., 5c; 1/4 lb., 10c; lb., 30c; 10 lbs., $\$ 2.50$.

New Chinese or Giant Southern Curled. Very large leaves; ready for use six weeks after sowing. Plants continue to yield until after frost. Leaves are eaten, bolled like spinach. Oz., 5c; $1 / 4$ lb., 15c; lb., 45c; 10 lbs., \$3.50.

Ostrich Plume. This is a valuable sort; produces large, curled leaves of excellent quality. If you enjoy a dish of greens this will please you, and it is a valuable market sort, being ready very early in the spring. Oz., 5c; 1/4 1b., 15c; lb., 55e; 10 lbs., \$5.00. 

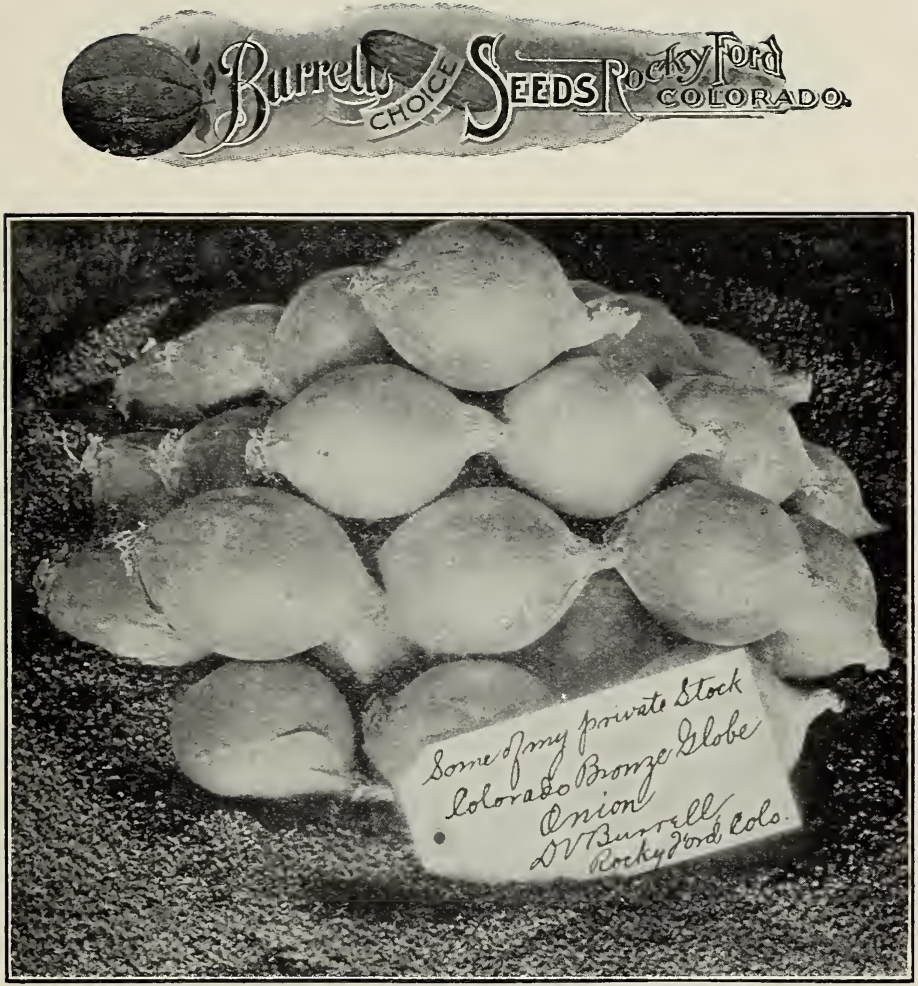

\section{Burrell's Private Stock, Colo- rado Bronze Globe Onion}

Add $8 \mathrm{c}$ per pound if by mail.

This very fine strain resulted from several years of careful selection by one of Colorado's most successful onion growers, from the Southport Yellow Globe. He made selections to secure an onion with a darker or bronze skin, also for a thicker outer skin, which means thicker layers through the onion.

This selection has resulted in a bronze onion, shaped as seen in the photograph and in 1906 his yield from four acres was 4,000 bushels. I bought the finest onions from this crop and it is from these onions that my seed originated. I have never seen a finer keeper or more uniform onion in shape and color.

If you plant onions to carry over for the winter and spring trade do not fall to plant liberally of this seed. I know it is extra fine and the price is low, as I have a fine lot of seed to offer. Pkt., 5c; oz., 10c; $1 / 41$ lb., 35c; lb., \$1.25; 10 lbs. and up, $\$ 1.15$ per 1 lb.

Southport Yellow Globe. This variety of onions is well known and very extensively planted throughout the East. Not so early as the Globe Danver, same color, an excellent keeper. It is a heavy yielder, of good size and one of the surest croppers. Pkt., 5c; oz., 10c; 1/4 lb., 35c; lb., \$1.25; $10 \mathrm{lbs}$. and up, $\$ 1.15$ per lb.

White Portugal or Silver Skin. A large, flat, white onion of mild and pleasant flavor; hard and fine grained, and a good keeper. More extensively sown for sets than any other variety, and is also largely grown for pickling. Pkt., 5c; oz., 15c; $1 / 4$ lb., 50c; lb., \$1.90; 10 lbs., \$18.50; 100 lbs., $\$ 180.00$.

Southport White Globe. Shape same as illustrated above. Color a clear white; an excellent cropper and the best keeper of the white varieties. Pkt., 5c: oz., 15c; 1/4 lb., 50c; lb., $\$ 1.90 ; 10$ lbs. and up, $\$ 1.85$ per lb. 

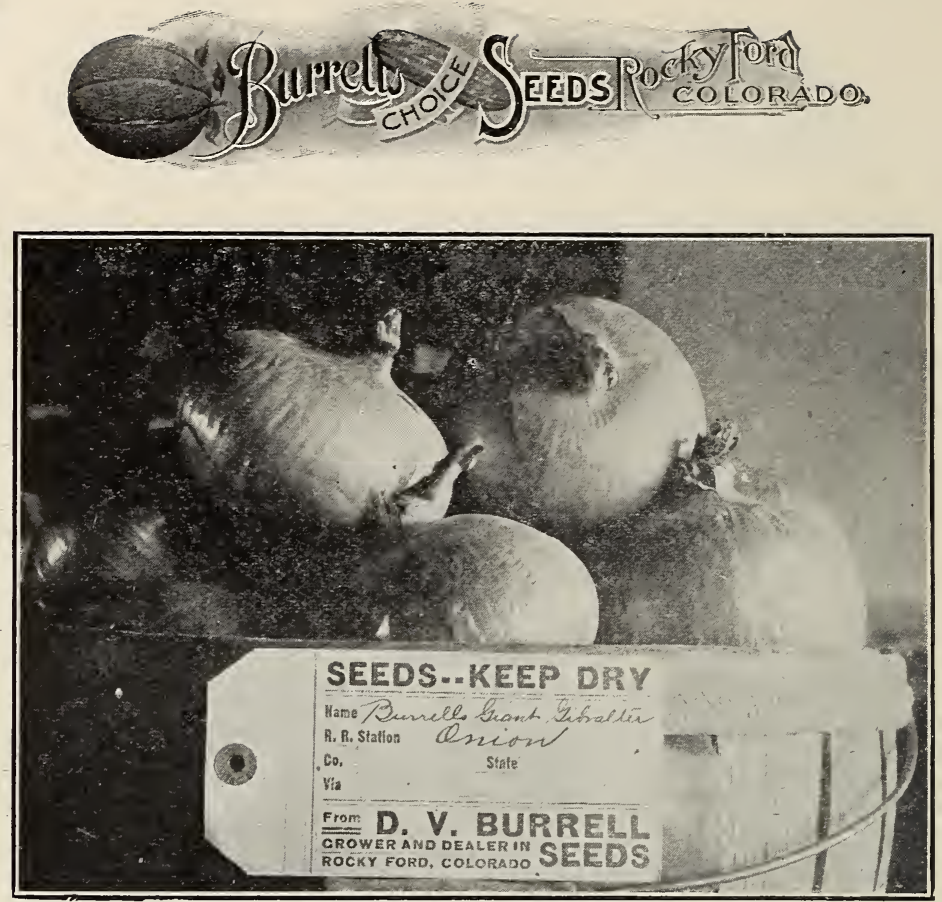

\section{Burrell's Giant Gibraltar Onion}

LARGESE OXION.

\section{verr MIID. VERY SHORT cRor.}

In the above illustration is shown a photograph of a half bushel of these onions.

It is a beautiful onion with thin skin of a light straw color. The flesh is white, mild and sweet. It makes a large, quick growth, is later and larger than the Prizetaker. Grown as a Spanish onion and crated, it is excellent for the fall and winter trade. It is a fine variety for display on vegetable stands, as it attracts much attention.

Pkt., 5c; oz., 20c; 1/4 lb., 65c; lb.. \$2.50; 10 lbs. and up, $\$ 2.40$ per lb.

Add $8 \mathrm{c}$ per pound if by mail.

Prizetaker. Quite like the above in color, but not so near flat, being nearly a perfect globe. Fundreds of acres of this sort are grown in single districts in Texas. This variety of recent introduction annually grows in favor. It is very productive, attractive in appearance and quality, being mild in flavor as the Imported Spanish onions of our grocers. Can be grown successfully in any locality where other onions are produced. The color is a bright straw, and it always grows to a uniform shape. Having a small neck, stiff necks are almost unknown. We call attention to this fact: Our seed is the choicest American grown, and not Imported Spanish King, as sold by some dealers at low prices under the name of Prizetaker.

Pkt., 5c; oz., 15c; 1/4 lb., 50c; lb., \$1.90; 10 lbs., \$18.50; 100 lbs., \$180.00.

Teneriffe Grown Red Bermuda. Imported by myself from the most reliable Teneriffe growers. This seed comes in sealed tin cans unless ordered in small lots. Pkt., 5c; oz., 15c; 1/4 lb., 50c; lb., $\$ 1.85 ; 10$ lb. lots, $\$ 1.80$ per lb.

Onions require very rich land, clean and careful cultivation. They can be successfully grown a number of years on the same land. Plant four pounds of seed per acre and do not thin too much. I lifted 20 inches of one row of onions this year which measured 36 inches when laid side by side touching each other. They grew close together and pushed each other out to the side. For best results from seed the young plants should stand $1 \frac{1}{2}$ to 2 inches apart. 

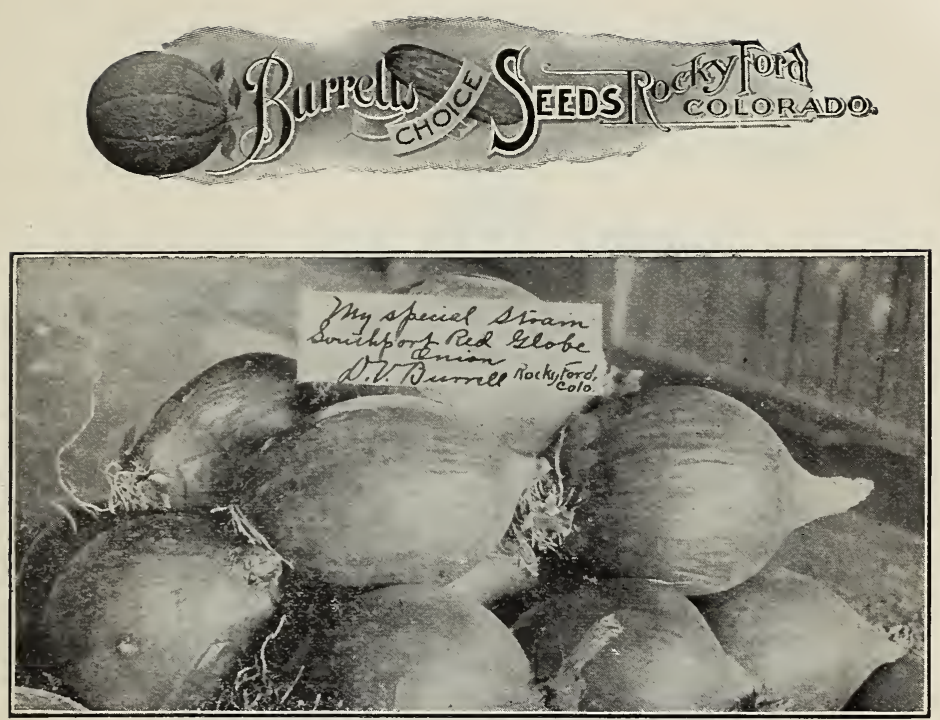

\section{Burrell's Special Stock, Southport Red Globe Onion}

The above is a photograph of some of my onions. The type is right and the quality of the best to be had. It matures nearly as early as the flat sorts, grows to a large size and is very mild and tender. It is a GOOD KEEPER and considered ONE OF THE BEST RED ONIONS. Add $8 \mathrm{c}$ per pound if by mail.

Pkt., 5c; oz., 15c; $1 / 4$ lb., 50c; lb., \$1.90; 10 lbs. and up, $\$ 1.85$ per lb.

\section{WHITE BERMUDA, TENERIFFE GROWN.}

I make a specialty of importing this seed and have to offer from the most reliable Teneriffe growers.

Pkt., 5c; oz., 15c; $1 / 4$ lb., 55c; lb., $\$ 2.00$; 10 lbs, and up; $\$ 1.90$ per lb.

Large planters wanting 50 pounds and up grown under contract 1911 crop will do well to write me for prices. I can ship direct from the custom house, insuring early delivery and make you lowest growing prices. Contract orders should be placed at once and not later than February 1, 1911.

\section{CRYSTAL WAX, TENERIFFE GROWN.}

This variety is grown extensively in Texas by the transplanting method. They are very mild, crystal white, and produce a larger onion than the White Bermuda. The seed I offer is of $\mathrm{my}$ own importation.

Pkt., 5c; oz., 25c; $1 / 4$ lb., 80c; lb., $\$ 3.00$; 10 lbs. and up, $\$ 2.80$ per lb.

\section{MAMMOTH SILVER KING.}

Of attractive shape, with silver white skin, and flesh of a most agreeable, mild flavor. It matures quite early and reaches a much larger size than any other of the flat varieties, frequently measuring 20 inches in circumference, and weigning from 3 to 5 pounds when well grown. Must he sown thinly to produce large onions. This is a fine sort to grow for exhibition purposes.

Pkt., 5c; oz., 16c; 1/4 lb., 40e; lb., \$1.40; 10 lbs., $\$ 13.60$.

Add $8 \mathrm{c}$ per pound to all varieties of onlons 15 by mail. 

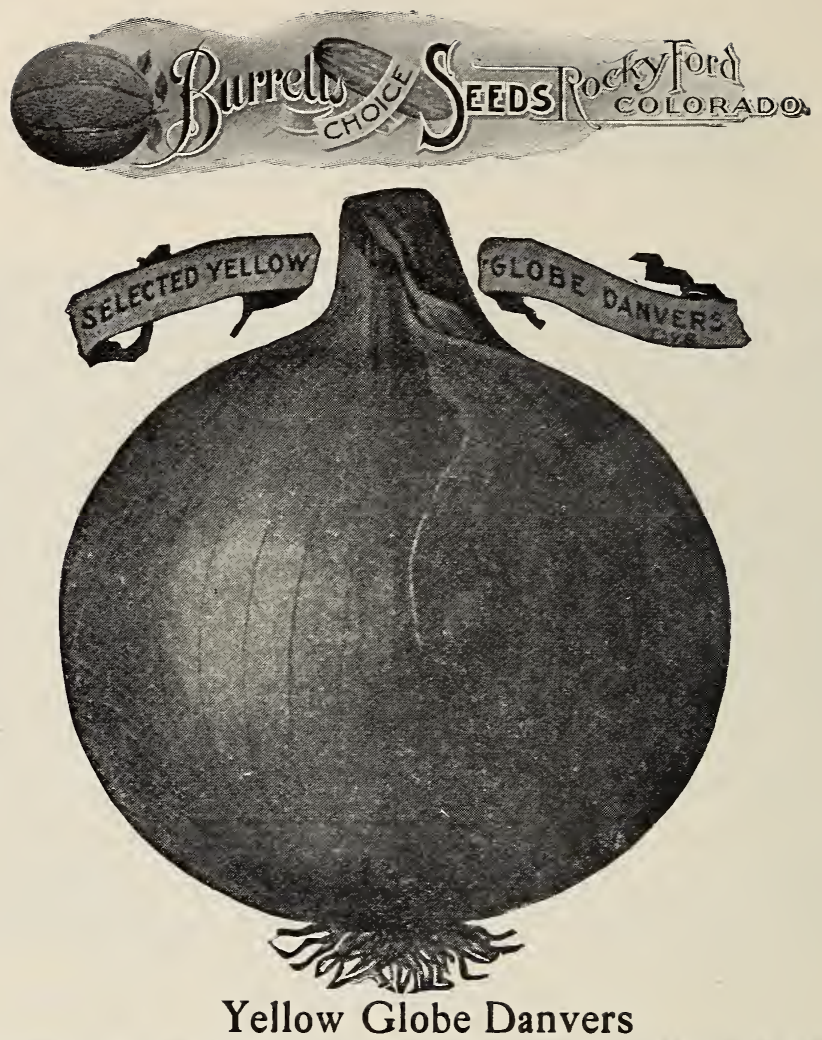

Undoubtedly the best known and most popular of all onions; the earliest yellow variety; is entirely free from stiff necks; globular in shape, has a small top. It is the most productive, producing as high as 1,000 bushels per acre, and will average on good soil with proper culture, 700 to 800 bushels.

Pkt., 5c; oz., 15c; 1/4 lb., 40c; lb., \$1.40; 10 lbs., \$1.35 per lb.

\section{Large Red Wethersfield}

It is fine grained and strong in flavor. Very productive and an excellent keeper. Immense crops of this are grown for shipment, and it certainly is one of the very best sorts for market.

Pkt., 5c; oz., 15c; 1/4 lb., 40c; lb., \$1.40; 10 lbs., \$1.35 per lb.

\section{Giant White Italian Tripoli}

El Paso or Large Mexican. Of large size and most beautiful form with fine white skin. The first season it will grow an onion from one to one and a half pounds. Pkt., 5e; oz., 15c; $1 / 4$ lb., 40c; lb., $\$ 1.40 ; 10$ lbs. and up, $\$ 1.35$ per lb.

\section{White Queen}

Very early, small pickling onion; the seed is also planted thick for bunching onions and at the rate of 60 to 70 pounds per acre for sets.

Pkt., 5c; oz., 10c; 1/4 lb., 30c; lb., \$1.10; 10 lbs. and up, $\$ 1.00$ per lb.

\section{White Pearl}

Quite similar to White Queen. Extensively planted for sets.

Pkt., 5c; oz., 10c; 1/4 lb., 30c; lb., $\$ 1.10 ; 10$ lbs. and up, $\$ 1.00$ per 1 .

\section{White Barletta}

When matured, the tops die down, leaving beautiful and perfect little bulbs. The color is pure white, flavor mild and delicate, perfectly adapted for plckling and table use, and makes a pretty bunch onion, especially if grown by the transplanting method. Pkt., Ec; oz., 16c; 1/4 lb., 46e; lb., \$1.50; 10 lbs. and up, \$1.40 per lb.

Add 80 per pound to price on all varietien of Onlons if by mall. 

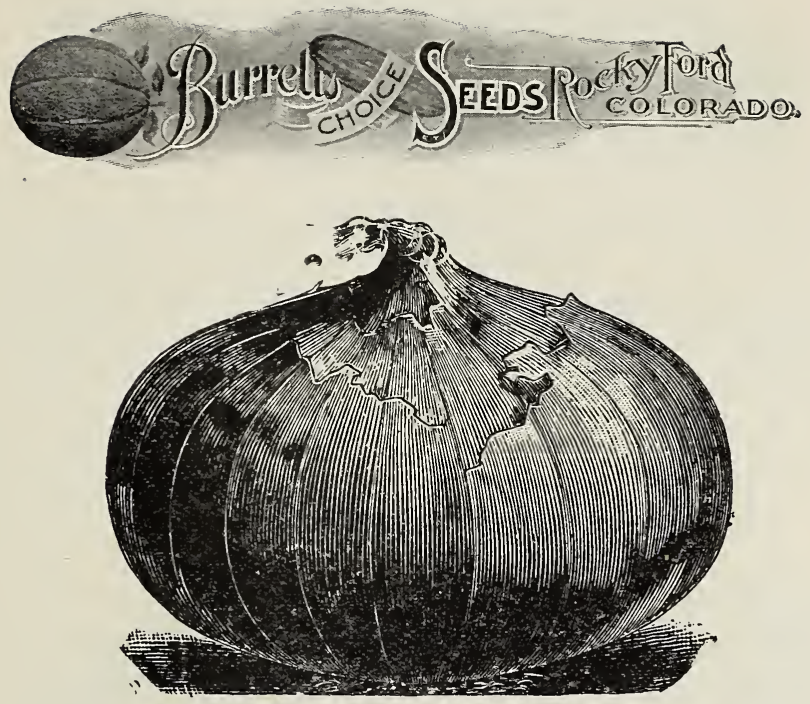

\section{Yellow Flat Danver Onion}

My strain of this well-known variety is of the very best, producing a uniform crop, which matures just at the right time for storing for winter. This seed sown thick ( 60 lbs. to the acre) produces very fine bottom sets. It is free from stiff necks; has a small top and is very productive.

Pkt., 5c; oz., 15c; $1 / 4$ lb., $40 \mathrm{c} ; 1 \mathrm{lb} ., \$ 1.40 ; 10$ lbs. and up, $\$ 1.35$ per $1 \mathrm{lb}$.

\section{Australian Brown Onion}

A valuable, early variety of medium size, hard and solid, attractive for market, both as to form and appearance. Never make any stiff necks or scullions. It has the reputation of keeping indefinitely. Color of the skin is a clear amber brown.

Pkt., 5c; oz., 15c; 1/4 lb., 40c; lb., \$1.10; 10 lbs. and up, $\$ 1.05$ per lb.

\section{Market Gardeners Bunching Onion}

This is the most valuable sort to plant in midsummer rather thickly and leave in the ground over winter for early spring bunching onions.

They are ready very early and are of excellent quality and appearance. The long white roots when cleaned and bunched get the best of the market.

Many growers plant 50 to 100 pounds at a time.

The past season the crop of seed was very short.

Pkt., 5c; oz., 10c; 1/4 lb., 35c; lb., \$1.35; 10 lbs. and up, $\$ 1.30$ per lb.

\section{Onion Sets}

These are grown from seed and will produce fine onions very early. A bushel weighs 32 pounds.

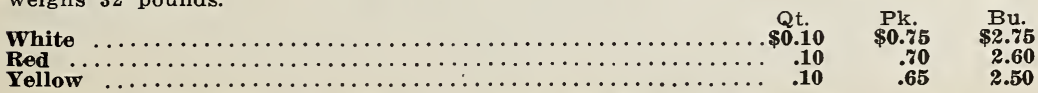

Add 10c per quart if by mail. By freight or express at purehaser's expense. 


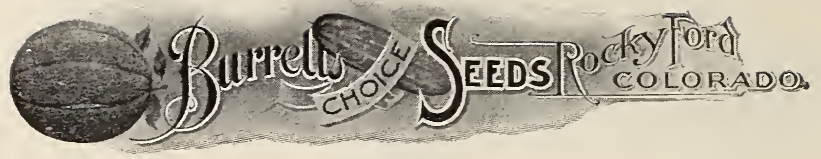

\section{Okra}

Add $8 \mathrm{c}$ per pound if by mail.

Extra Early Dwarf (Green Pods). Very early and productive. Oz., 5c; 1/4 1b., 15c; Ib., 40c; 10 lbs., \$3.00.

Early Dwarf White (White Pods). Pods extra long when fully matured, measuring a foot in length and very thick and fleshy; early and prolific. Fine for soups. Oz., 5c; 1/4 lb., 15c; lb., 40c; 10 lbs., $\$ 3.00$.

White Velvet. A great improvement over older varieties; pods larger, white, very smooth, a more abundant bearer; superior quality. Oz., 5c; 1/4 1b., 15c; lb., 45c; 10 lbs., \$3.50.

\section{Pumpkins}

\section{Extra Fine Japanese Pie}

This is one of the finest varieties of Pumpkins. Color of rind, dark slate green with very slightly lighter mottled stripes. The neck is very large in proportion to the size of the bowl and in it the meat is solid. In quality none can surpass it. Color of meat, very deep orange red, giving the pies that richest pumpkin color as well as flavor. It is a heavy yielder and where squash bugs bother the vines it succeeds better than any other sort. The seeds are peculiarly marked as if covered with Japanese characters, hence its name.

Pkt., 5c; oz., 10c; 1/4 lb., 25c; lb., 80c; 10 lbs. and up, roc per lb.

Add $8 \mathrm{c}$ per pound if by mail.

Small Sugar Pumpkin. This is the New England Pie Pumpkin, small, round, yellow; of excellent quality, and an abundant yielder; a single vine yields 8 to 10 pumpkins. Pkt., 5c; oz., 10c; 1/4 lb., 20c; lb., 60c; 10 lbs. and up, 50c per lb.

Large Sweet Cheese. Flat. creamy yellow, well known; one of the standard sorts. Oz., 5c; $1 / 4$ lb., 15c; lb., 50c; 10 lbs, and up, 40c per lb.

Connecticut Field. The well-known, large, yellow, Fleld Pumpkin.. 1/2 lb., 15c; lb., 25c; 10 lbs. and up, 20c per lb.

Michigan Mammoth. Simflar to above, only extremely large. Oz., 5c; 1/2 lb., 20c; lb., 40c; 10 lbs. and up, $35 c$ per $1 b$.

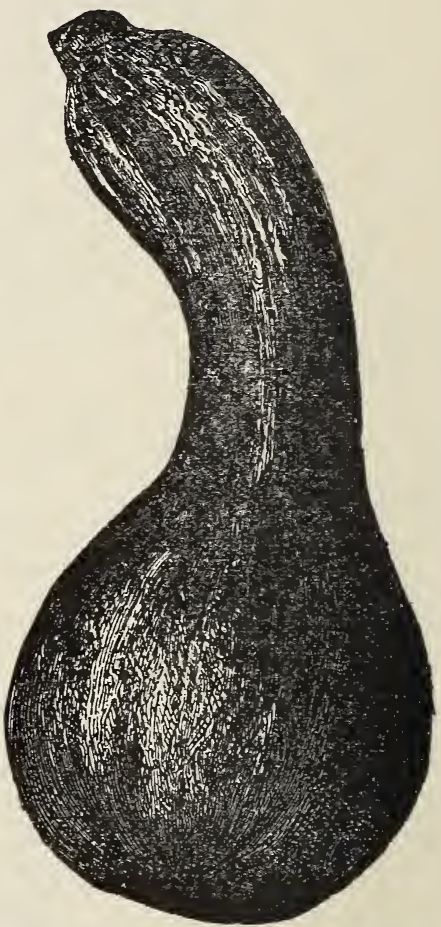

King of Mammoths. This is the exhibltion pumpkin for the fair, often weighing 150 to 200 pounds. In quality none are better for pies, and except where the black squash bug is bad it always yields heavily Outer color, light creamy red; meat deep orange red. Note-Often this seed from a big specimen is sold at $5 \mathrm{c}$ per seed to those who do not know it by name. Pkt., 5c; oz., 10c; 1/4 lb., 30c; lb., $\$ 1.00$; 10 lbs. and up, 90e per lb. 


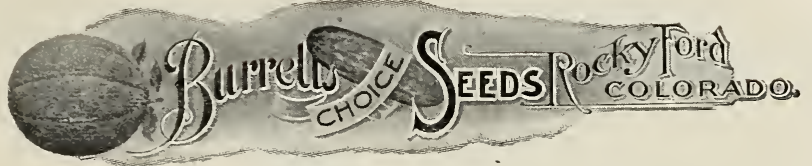

\section{PARSLEY}

Champion Moss Curled. Is a prize winner English varlety, in appearance like a tuft or finely curled moss, and of a rich deep green color. It is slow to run to seed and very hardy; of easiest growth; a few seeds sown in onion rows use no space; grows in window boxes. Extra fine for garnishing and culinary purposes. Oz., 5c; $1 / 4$ lb., 15c; lb., 50c; 10 lbs., \$4.50.

Fine Double Curled. A standard variety; plants bear an abundance of finely curled leaves; very ornamental. Oz., 5c; 1/4 lb., 15c; lb., 50c; 10 lbs., \$4.50.

Emerald Curled. Extra fine; the leaves are very finely curled, and of a deep emerald green color; very easy grower and none finer. Oz., 5c; 1/4 lb., 15c; lb., 50c; 10 lbs. and up, $45 \mathrm{c}$ per lb. Add $8 \mathrm{c}$ per pound to all above items if by mail.

\section{PEAS $==$ ALASKA}

The very best early green seeded variety. The dark green color of the pods makes it an excellent pea for shipping long distances. Very early and uniform grower. A popular sort with canners and shippers. First-class in every respect. Height $21 / 2$ feet. My crop the past season of these was very good and I am giving you the benefit of this in both quality and low prices.

Pt., 15c; qt., 25c; pk., \$1.45; bu., \$5.50; 5 bu. lots, $\$ 5.40$.

First and Best. A very good strain, only two or three days later than the Alaska. It is largely planted by truckers. Pt., 10c; qt., 20c: pk., $\$ 1.30$; bu., $\$ 5.00 ; 5$ bu. lots, $\$ 4.90$ per bu.

Tom Thumb. A very early variety which grows only about ten inches high. It yields well. Is good for small gardens. Pt., 10c; qt., 20c; pk., 1.30; bu., \$5.00; 5 bu., $\$ 4.90$ per bu.

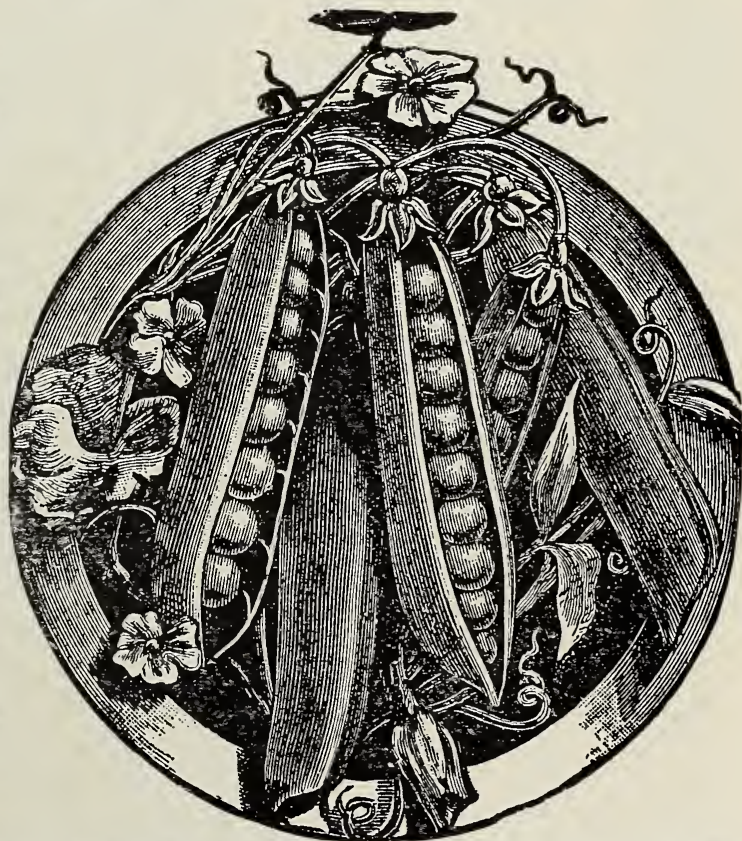

American Wonder. One of the earliest wrinkled peas of very good quality; grows about ten inches high and is very productive. Pt., 15c; qt., 25c; pk., \$1.60; bu., $\$ 6.00 ; 5$ bu., $\$ 5.90$ per bu.

McLean's Little Gem.. One foot high; bears heavily and of excellent quality: slightly later than the American Wonder. A favorite sort. Pt., 15c; qt., 25c; pk., $\$ 1.60$; bu., $\$ 6.00 ; 5$ bu., $\$ 5.90$ per bu.

Nott's Excelsior. This extra fine pea will stand planting very early, almost as soon as the smooth sorts, and produces fine, large pods, one-third larger than American Wonder. Dwarf in habit; height one foot. Pt., 15c; qt., 252; pk., \$1.70; bu., \$6.50; 5 bu., $\$ 6.35$ per bu.

Stratagem. This grows about 18 inches high and continues long in bearing. It yields well and is a very desirable sort. The pods are some times five inches long, and always well filled. Pt., 10c; qt., 20c; pk., $\$ 1.40 ;$ bu., $\$ 5.45 ; 5$ bu., $\$ 5.35$ per bu.

Pride of the Market. A productive variety bearing large very dark green pods, tightly filled with green partly wrinkled peas of good quality Well liked for both home and market growing. Pt., 10c; qt., 20c; pk., $\$ 1.40 ;$ bu., \$5.45; 5 bu., \$5.35 per bu. Add $8 \mathrm{c}$ per pint, $15 \mathrm{c}$ per quart, to above prices if by mall. 


\section{Dwarf Telephone or Carter's Daisy}

I market-gardened a number of years, and if I were offered only two varieties of peas I would choose Alaska for early and Dwarf Telephone for main crop. It is a cross between the Standard Telephone and Stratagem, and is an improvement on both of these varieties. It grows 18 inches high and yields an abundance of long, well-filled pods, containing from 7 to 11 large wrinkled peas of the finest quality. Crop very short.

Pt., 20c; qt., 40c; pk., $\$ 2.00$; bu., \$7.50. TELEPHONE.

This valuable and well-known sort grows about 40 inches high and yields an abundance of choice peas. The pods are very large and well filled. A choice market sort.

Pt., 15c; qt., 25c; pk., \$1.75; bu., $\$ 6.50$.

Large White Marrowfat. Late variety, large, well-filled pods. Vines hardy, strong and vigorous; pods fine, broad and of a leathery appearance and borne near the top of the vine. Contain 5 to 6 large peas of good substance and flavor, but not so sweet as the wrinkled sorts. For many years this has been used in immense quantities by canners. The peas are large, round, white and slightly oval. Height of vine, $31 / 2$ feet. Pt., 10c; qt., 20c; pk., $\$ 1.00$; bu., \$3.75.

Black-Eyed Marrowfat. Growth and general characteristics similar to the above. The peas have a distinct black eye, which does not show when they are in the green state. Is more prolific than the white. Pt., 10c; qt., 20c; pk., \$1.00; bu., $\$ 3.75$.

Melting Sugar. There is a class of peas little known in this country, but much used abroad, in which the large, sweet, brittle and succulent pods have none of the tough inner lining found in the ordinary varieties of garden peas. They are used in the same way as snap or string beans. The best of these edible podded sorts is the Melting Sugar, of which we offer a very fine strain. The pods are very large, extremely tender, fine flavored, and are borne in great abundance on vines 4 to 5 feet high. Pt., 15c; qt., 25c; pk., \$1.85; bu., $\$ 6.90$; 5 bu., $\$ 6.75$ per bu.

Horsford's Market Garden. This is one of the finest sorts and "shells out" a large number of choice peas. The pods are large, well filled, and of good color. The pods are produced in pairs. Height 18 inches.

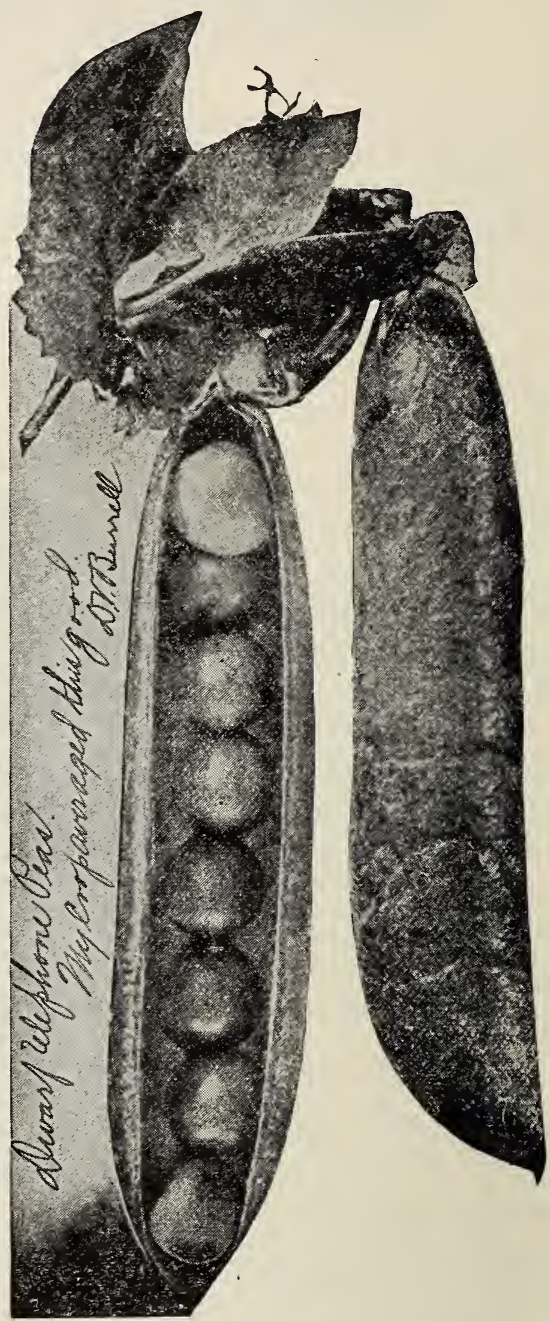
Pt., 10c; qt., 20c; pk., \$1.40; bu., $\$ 5.45 ; 5$ bu., $\$ 5.35$ per bu.

Yorkshire Hero. This sort produces well and the peas, 5 to 7 to the pod, are very large and of fine quality. The baskets weight well. Height 16 inches. Pt., 10c; qt., 20c; pk., \$1.40; bu., \$5.45; 5 bu., \$5.35 per bu.

Bliss Everbearing. A late variety which grows about 24 inches high and continues long in yielding. The peas are of excellent quality. Pods contain 5 to 7 peas so closely filled that while in edible condition they weigh nearly one-fifth more than most other sorts. Pt., 10c; qt., 20c; pk., $\$ 1.20 ;$ bu., $\$ 4.60 ; 5$ bu., $\$ 4.50$ per bu. Add $8 \mathrm{c}$ per pint, $15 \mathrm{c}$ per quart, if by mail. 


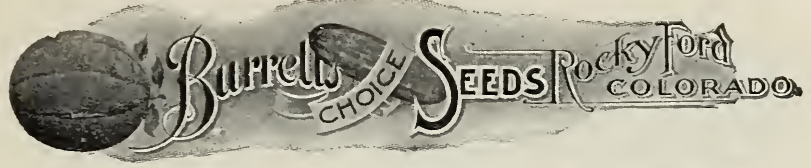

\section{Parsnips}

I sell thousands of pounds of parsnip seed and invite your attention to the following standard sorts. Note the price for tested seed of highest vitality. I know it should please you.

\section{I'I.AN'T HOLIOW CROWN OR LARGE} SCLAR FOR THE BEST.

Add $8 \mathrm{c}$ per pound if by mail.

Hriluil Crown or Large Sugar. This is a very desirable sort, and should be in every garden. It is very productive, large, and none better for table use. Oz., 5c: 1/4 lb., 10c; lb., 35c; 10 lbs., $30 c$ per lb.; 25 los. and up, 25 e per $1 b$.

Guernsey. A very fine variety which does not grow so long as the Hollow Crown, but broader shouldered. It is easily gathered, and yields an abundance of very smooth, fine grained roots. Oz., Jc; $1 / 4$ lb., 10c; lb., 35c; 10 lbs., 30c per lb.; 25 los. and up, 25c per lb.

\section{Peppers--Select Giant Ruby King}

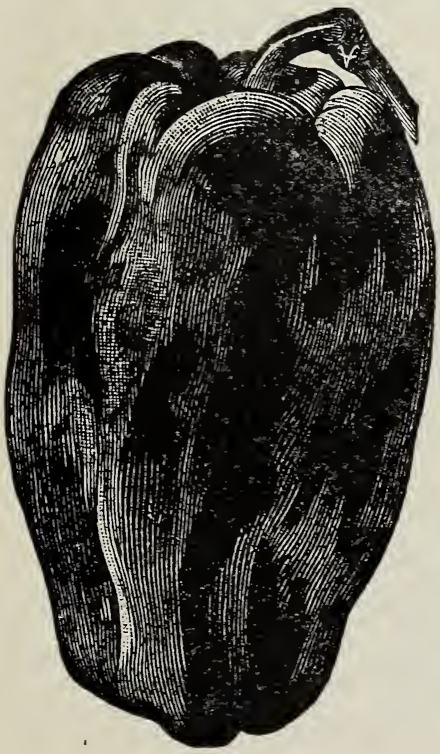

\section{Hollow Crown Parsnips}

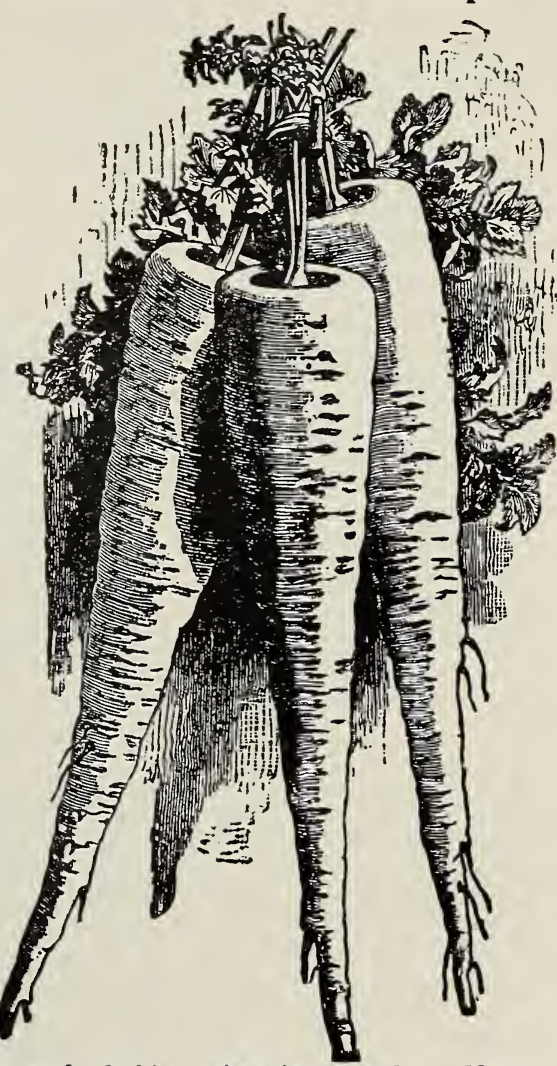

My seed of this variety is exuta fine. Many who planted it for market season 1910 report having grown the finest and most profitable crop they ever grew. I sell large quantities of this seed to individual growers and associations.

The fruits ?re very large, often measuring five inches in length and 3 to $3 \frac{1}{2}$ inches in diameter. AN EXCELLENT MANGO PEP. PER.

The best and most profitable mild red pepper for market or family use; so sweet and mild that they can be eaten raw, like an apple; largest size:

Pkt., 5c; oz., 25c; 1/4 lb., 80c; lb., \$3.00; 5 lbs. and up, $\$ 2.90$ per lb.

Chinese Giant. Very large, extra fine, well known by market growers. Pkt., 5c; oz., 40c; $1 / 4$ lb., \$1.40; lb., \$5.25. 


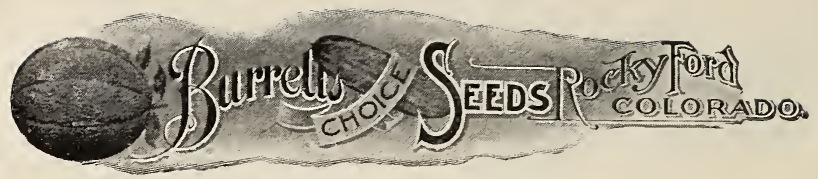

\section{Peppers--Continued}

Long Red Cayenne. A small, long, bright red sort, very productive, extremely strong and pungent. Pkt., 5c; oz., 15c; 1/4 lb., 50c; lb., \$1.75.

Large Bell or Bull Nose. A favorite and well-known pickling sort; is early, large, mild and thick skinned. Pkt., 5e; oz., 15e; 1/4 lb., 50c; lb., \$1.75.

Mammoth Golden Queen. One of the largest, handsomest and most productive of all varieties; color bright golden yellow; large as Ruby King; flavor mild and pleasant. Pkt., 5c; oz., 20c; 1/4 lb., 60c; lb., \$2.30.

Sweet Spanish. Grows to very large size; sweet flavor; fine for salad. Pkt., 5c; oz., 20c; $1 / 4$ lb., 60c; lb., $\$ 2.30$.

Mexican Chili. Used by the Mexicans in making the famous chili con carne and hot tamales. Grows from 3 to 5 inches long and quite pointed. Requires a long, warm season. Plants should be started quite early in hot beds. I offer my customers the following low prices on this seed: Pkt., 5c; oz., 15c; 1/4 lb., 40c; lb., $\$ 1.40$.

Red Cherry. Plants tall, bearing a profusion of bright red, round fruit, which is very pungent when ripe. The plant is very handsome and an ornament to the garden. Pkt., 5c; oz., 25c; 1/4 lb., 70c; 1b., \$2.70.

Cardinal. A new pepper with long, curved, tapering pods, about 2 inches thick at the stem end; very sweet and tender, and exceedingly handsome. Nothing equals it in depth, purity and brilliancy of color. It is worthy of cultivation for its beauty alone. Pkt., 5c; oz., 15c; 1/4 lb., 50c; lb., $\$ 1.75$.

Add $8 \mathrm{c}$ per pound if by mail.

\section{Rhubarb}

Linnaeus. An early and very fine variety; leaves and stalks very large, juicy and tender. Grows quickly, producing fine, succulent stalks. Pkt., 5c; oz., 10c; 1/4 lb., 35c; lb., $\$ 1.35 ; 5$ lbs., $\$ 6.00$.

Victoria. Later than the Linnaeus, but equally as large and good. Pkt., 5c; oz., 10c; $1 / 4$ lb., 35c; lb., \$1.35; 5 lbs., \$6.00.

Rhubarb Roots. Linnaeus, cut two and three eyes to the clump. Doz., 50c; 100, $\$ 2.00 ; 1,000, \$ 18.00 ; 10,000, \$ 16.00$ per $\mathbf{M}$. These prices at buyer's expense; express or freight. No charge for package.

\section{Radish}

Early Scarlet Turnip. A fine, quick growing sort; small, round, crisp, tender, of good eating qualities. Oz., 5e; 1/4 1b., 15c; lb., 50c; 10 lbs., \$4.50.

Rosy Gem or White Tipped Forcing. One of the quickest sorts and of excellent quality. Bright scarlet, with white tips; of fire appearance. Oz., 5c; 1/4 lb., 15c; lb., 50c; 10 lbs., \$4.50.

Early White Turnip. Of quick growth; roots round, white, with small tops. Good for forcing or open ground. Flavor very good. Oz., 5e; 1/4 lb., 15c; 1b., 50c; 10 lbs., \$4.50.

French Breakfast. (Olive shaped.) Deep crimson with white tips. A well-known and equally well-iiked variety. One of the best early radishes. Oz., 5c; $1 / 4$ lb., 15c; lb., 50c; 10 lbs., \$4.50.

Early Scarlet. (Olive Shaped.) Oval, very tender, and good quality; fine for forcing or open ground.. Oz., 5c; 1/4 lb., 15e; lb., 50c; 10 lbs., $\$ 4.50$.

Surprise. (Olive shaped.) Skin brown, flesh white, crisp and tender. Oz., 5c; 1/4 lb., 15e; lb., 50c; 10 llıs., \$4.50.

Early White. (Olive shaped.) Small, sweet and crisp. Like the other olive-shaped sorts except in color. Oz., 5c; 1/4 lb., 15c; lb., 50c; 10 lbs., \$4.50.

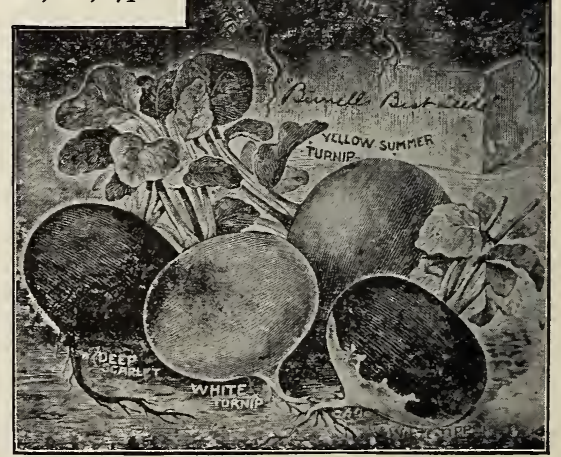




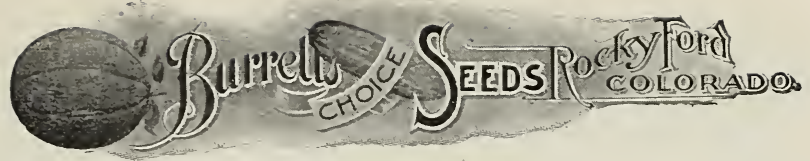

\section{Burrell's Long Cincinnati Market}

\author{
Special Market Gardeners' Strain.
}

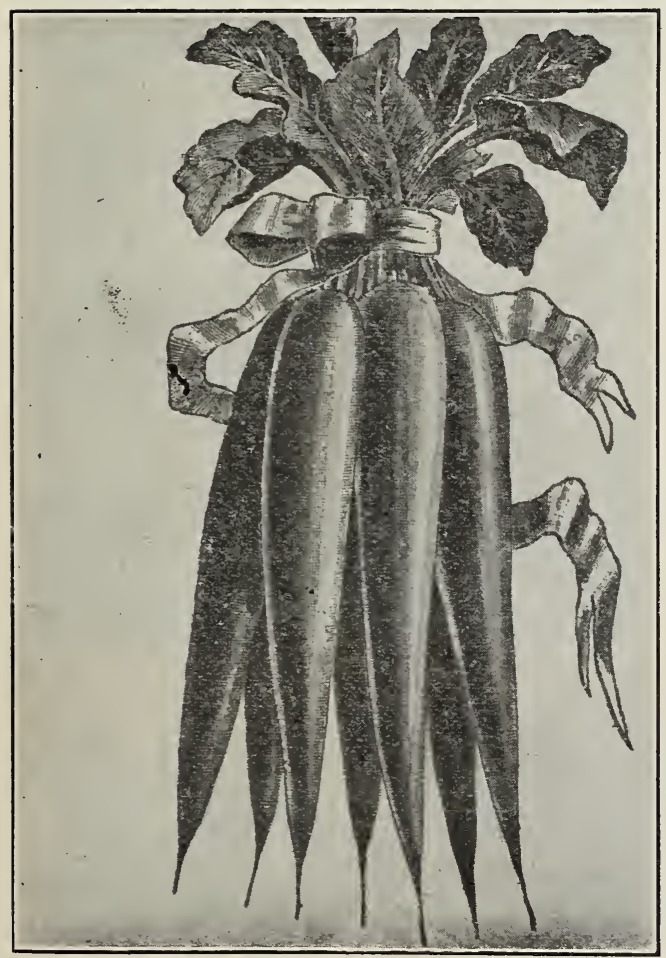

Single Market Gardeners buy 50 to 100 pounds of this seed from me at a time. The finest Long, L i g h t, Scarlet Radish, nearly transparent, small tops, will stand planting close together, slow to run to seed; $\mathrm{grow}$ s straight and sinooth, 6 to 8 inches long, tender, crisp and does not become hollow and pithy. If you grow for market and plant only two sorts they should be my Long Cincinnati Market and New White Icicle. Price: Pkt., 5c; oz., 10c; $1 / 4$ lb., $20 \mathrm{c} ; 1 \mathrm{~b} ., 65 \mathrm{c} ; 10$ lbs. up to 40 lbs., $60 \mathrm{c}$ per lb.; 40 lbs. and up, 55c per $1 b$.

Long Chartier. A wellliked sort, which attains a very large size before becoming unfit for use. Color, red at the top, changing to pink in the middle and white at the tip. Many market gardeners plant this exclusively for their market trade. Oz., 5c; 1/4 lb., 15c; lb., 50c; 10 lbs., $\$ 4.50$.

Long Scarlet. Short Top. The standard long variety. Well known for a long time. Good for home or market garden. Roots long, g row in g partly above the ground; straight, smooth, rich red, and of fine quality; a quick grower. Oz., 5c; 1/4 lb., 15c; lb., 50c; 10 lbs., \$4.50.

I. ong Brightest Scarlet. This new sort much resembles Long Scarlet in shape, but is slightly shorter. It is a very bright scarlet with a white tip and very attractive in appearance. The quality is extra good and it matures quickly. It is a good seller and fine for home gardens as well. Oz., 5c; 1/4 lb., 15c; lb., 50c; 10 lbs., \$4.50.

California White Winter. Is really a Chinese Radish, grown by the Chinese in California. White, solid, of good flavor, and a long keeper; 8 to 10 inches long, and 2 to 3 inches in diameter. Oz., 5c; 1/4 1b., 15c; lb., 50c; 10 lbs., \$4.50.

Long Black Spanish. Black skinned, large roots, sîightly pungent, hardy. Oz., 5c; $1 / 4$ lb., 15c; lb., 50c; 10 lbs., \$4.50.

Early Scarlet Globe. This valuable early sort is one of the finest for extra early; color very deep scarlet; very solid, slow to get pithy, and very desirable for the home garden or early home market. Excellent to grow under glass. Pkt., 5c; oz., 10c; $1 / 4$ lb., 20c; lb., 65c; $10 \mathrm{lbs}$. and up, 60c per lb. 


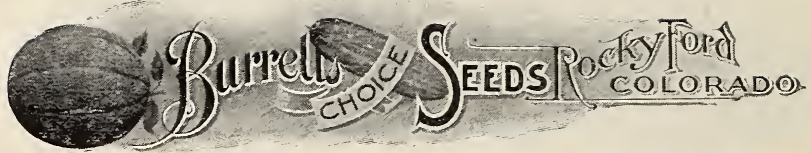

\section{NEW WHITE \\ ICICLE RADISH \\ Burrell's \\ Select \\ Seed}

This beautiful transparent white variety much resembles the White Vienna. It is of excellent quality. Under favorable conditions stands a long time without going to seed and remains crisp and tender.

It is a sort which should be included in every order suitable for forcing and none better for the home or market garden.

Add $8 \mathrm{c}$ per pound if by mail.

Price: Pkt., 5c; oz., 10c ; $1 / 4$ lb., 20c; lb., 65c; 10 lbs. and $u p, 60 c$ per $l b$.

WHITE VIENNA OR IADY FINGER.

Remaining long in edible condition; always sweet, crisp and tender, and of excellent quality. I hope to find this sort in every order and $\mathrm{I}$ know you will be pleased.

Oz., 5c; 1/4 lb., 15c; lb., 50c; 10 lbs., \$4.50.

WHITE STRASBURG

A large, white, attractive variety of medium length; matures early and remains for a long time in edible condition.

Oz., 5c; 1/4 lb., 15c; lb., 50c; 10 lbs., \$4.50.

Add $8 \mathrm{c}$ per pound if by

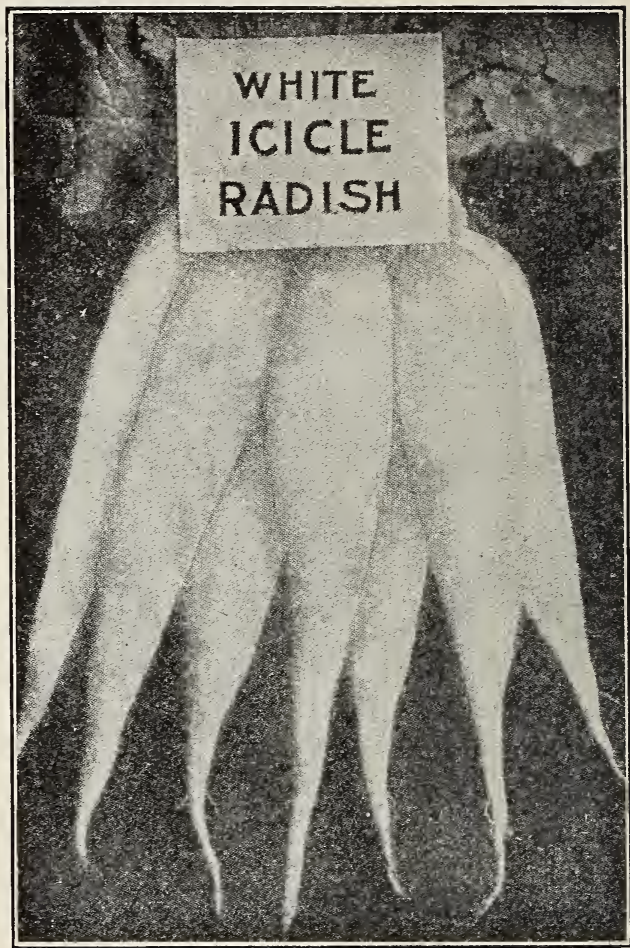
mail.

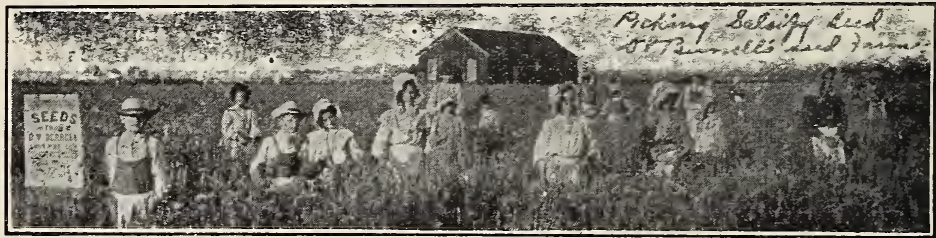

Salsify $==$ Mammoth Sandwich Island

This large sort is the most profitable to grow. It is white, of good flavor and an excellent sort for market. See view Picking Salsify on my seed farm above.

Price: Pkt., 5c; oz., 10c; 1/4 lb., 25c; lb., 90c; 5 lbs. and up, 80e per lb.

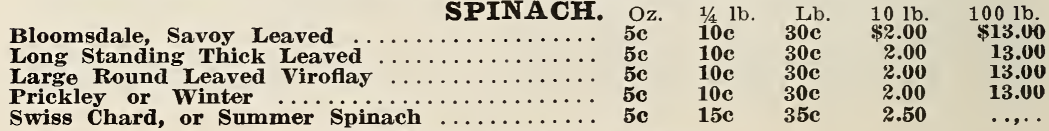



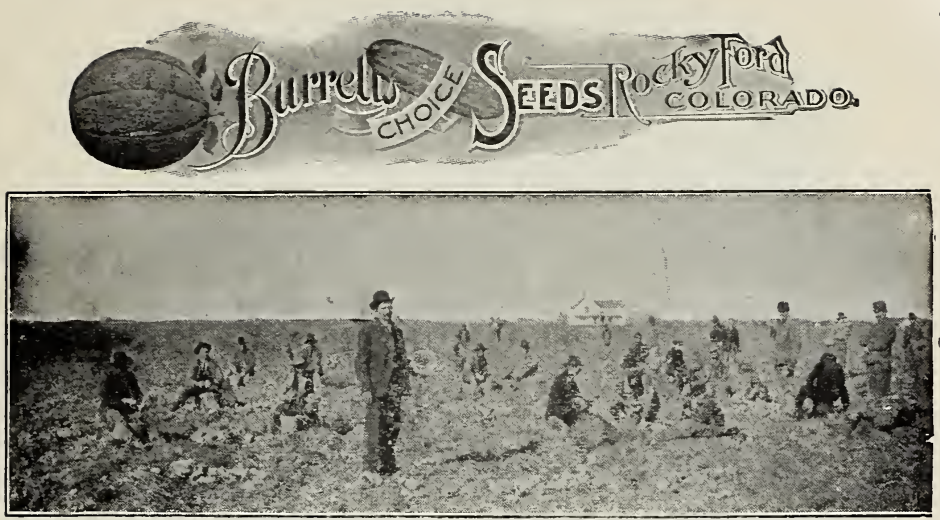

\section{Burrell's Select Early Mammoth White Bush Squash}

\section{EARLIEST FINEST STRAIN FOR MARKET GARDENERS.}

I grow a large acreage of squashes for seed and call your attention to the photograph taken in one of my fields. When you buy of me you are getting the seed from the grower and can be assured of the fact that I take the greatest care to have the seed right in quality.

This squash is very early and just the right size for market. The bush habit is well established and the uniform appearance makes it a profitable sort when it comes to packing, as the fruits all look altke.

Price: Oz., 5c; 1/4 lb., 15c; lb., 50c; 10 lbs., 45c per lb.; 50 lbs. and up, $40 c$ per lb. Add $8 \mathrm{c}$ per pound if by mail.

EARLY MAMMOMH YELLOW SUMMER CROOKNECK SQUASH.

My strain of this sort is right. It is the finest crookneck for early market. The fruits quickly reach a desirable size for market, are attractive in appearance and rich in quality. My strain is heavily warted, uniform in shape and yields heavy.

Price: Oz., 5c; 1/4 lb., 15c; lb., 50c; 10 lbs., 45c per lb.; 50 lbs. and up, $40 c$ per lb. Add $8 \mathrm{c}$ per pound if by mail.

DWARF WHITE BUSH SCALLOP.

A small, well-known sort much grown for market. Bush habit not so well established as Mammoth White Bush.

Oz., 5c; 1/4 lb., 15c; lb., 55c; 10 lbs., \$5.00; 100 lbs., \$45.00.

\section{FORDHOOK VINE.}

This valuable squash is not so well known as it deserves as every garden should contain some of them, owing to their fine quality and the fact that they are less bothered by bugs than any other sort. The skin is bright yellow; flesh straw yellow; one of the best keeping and handsomest winter varieties. Small and very convenient family size.

Pkt., 5c; oz., 10c; 1/4 lb., 25c; lb., 70c; 10 lbs., \$6.50; 100 lbs., \$60.00.

\section{BOSTON MARROW.}

Second early, coming in about ten days after the Bush and Crookneck sorts. Skin yellow, very thin; the flesh dry, fine grained and of good flavor. Very extensively used by canners. Easily grown.

Pkt., 5c; oz., 10c; 1/4 lb., 25c; lb., 65c; 10 lbs., $\$ 6.00 ; 100$ lbs., $\$ 55.00$.

\section{MAMMOTH CHILI.}

Rich orange yellow; always grows to an enormous size, often weighing 200 pounds or more. Very profitable for stock feeding and much grown for exhibition purposes. $\quad$ Pkt., 5c; oz., 10c; 1/4 lb., 30c; lb., \$1.00; 10 lbs., \$9.00.

\section{MAMMOTH WHALE.}

Flesh solid; color a bright orange; quality very fine; enormous size.

Pkt., 5c; oz., 10c; 1/4 lb., 30c; lb., \$1.00; 10 lbs., $\$ 9.00$.

\section{IMPROVED MARBLEHEAD.}

Much resembles the Hubbard; an excellent keeper; shell gray and very hard; flesh bright orange color; requires the whole season to mature.

Pkt., 5c; oz., 10c; 1/4 lb., 25c; lb., 70c; 10 lbs., \$6.50; 100 lbs., \$60.00.

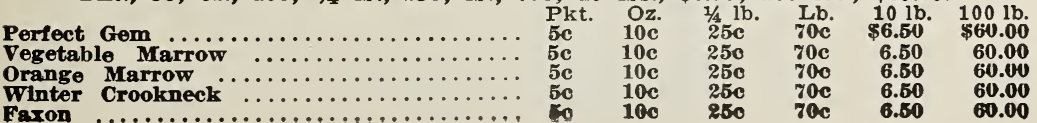




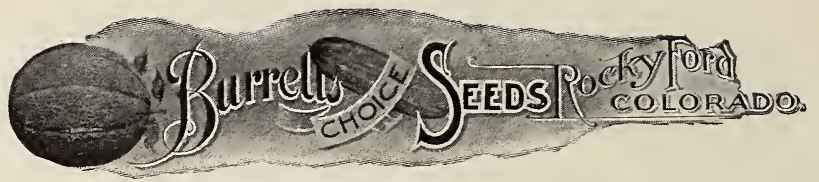

\section{Squash=Continued}

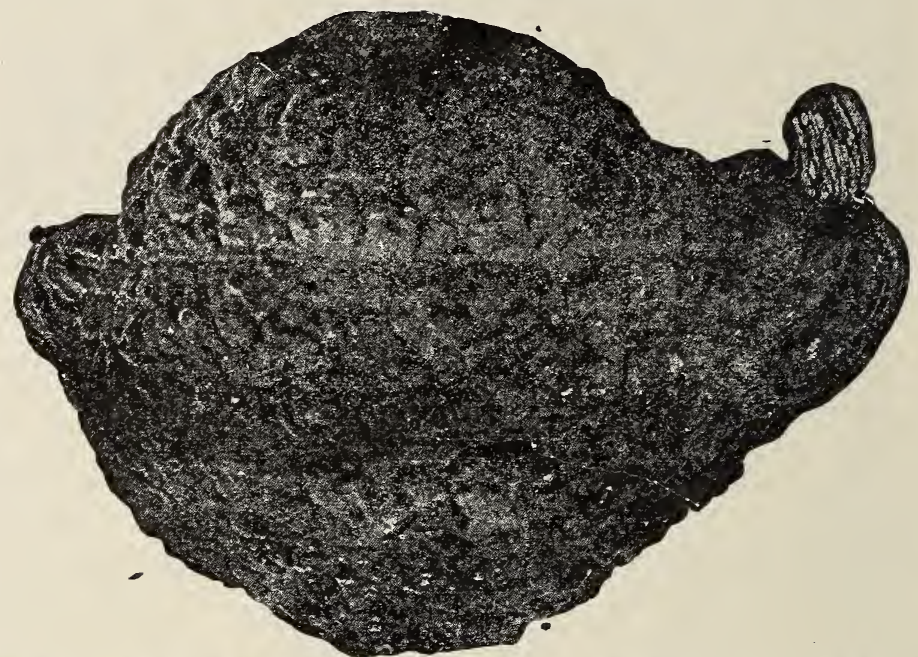

Hubbard. This is the standard variety and has no superior. If you are planting but one variety for winter I would recommend that this be the Hubbard. It is a favorite both for market and home use. Good specimens are about equal to the sweet potato. The shell is hard and dry. and with some care can be kept until late in the spring. My strain is very fine. Pkt., 5c; oz., 10c; 1/4 lb., 25c; lb., 70c; 10 Ibs., \$6.50; 100 Ibs., \$60.00.

Chicago Warted Hubbard. This very fine varlety much resembles the Original Hubbard except that it is larger and more covered with warts. Can be kept until late spring. The shell is very hard and dry. Pkt., 5c; oz., 10c; 1/4 1b., 25c; 1b., 70c; 10 lbs., \$6.50; 25 lbs. and up, 60c per lb.

Golden Hubbard. This is slightly smaller than the Original Hubbard and instead of having a slate green rind it is a rich golden color. In quality it is unsurpassed. It is an excellent keeper. Pkt., 5c; Oz., 10c; 1/4 Ib., 30c; lb., 90c; 10 lbs. and up, 85c per lb.

Golden Bronze. A very fine sort; flesh thick, deep reddish orange color; fine grained and of excellent flavor. A good keeper; shape oval, largest at blossom end; the rind is golden bronze in color when ripe. Pkt., 5c; oz., 10c; 1/4 Ib., 30c; lb., 90c; 10 lbs. and up, 85e per 1 .

Pike's Peak. An excellent sort, rather long for Its thickness; slate colored rind; flesh creamy yellow, of good flavor; a good keeper. Pkt., 5c; oz., 10c; 1/4 lb., 250; lb., $80 \mathrm{c} ; 10$ lbs. and up, 75e per lb.

\section{Add $8 \mathrm{c}$ per pound if by mall.}

\section{LARGE PLANTERS AND ASSOCIATIONS.}

Contract a year ahead for your seeds and get grown just what you want.

I have the best possible facilities to produce seeds for you that you can depend upon. Grown and selected in the way you want.

Such seeds as mature better at some other points than here, I have arrangements to grow them there. For example: Transplanted Radish-France; Bermuda Onion Seeds-Teneriffe Islands; Danish Ball Head Cabbage and Caullflower in Denmark, etc. Tomato, Vine seeds and many others here at Rocky Ford.

I can deliver you the best seeds and save you money, but I will not sacriflce the quality to make low prices. I know you want quality frst, then a reasonable price. Send me a list of the varieties and quantity you buy and how jou want it grown and selected, and you'll hear what I will do. 


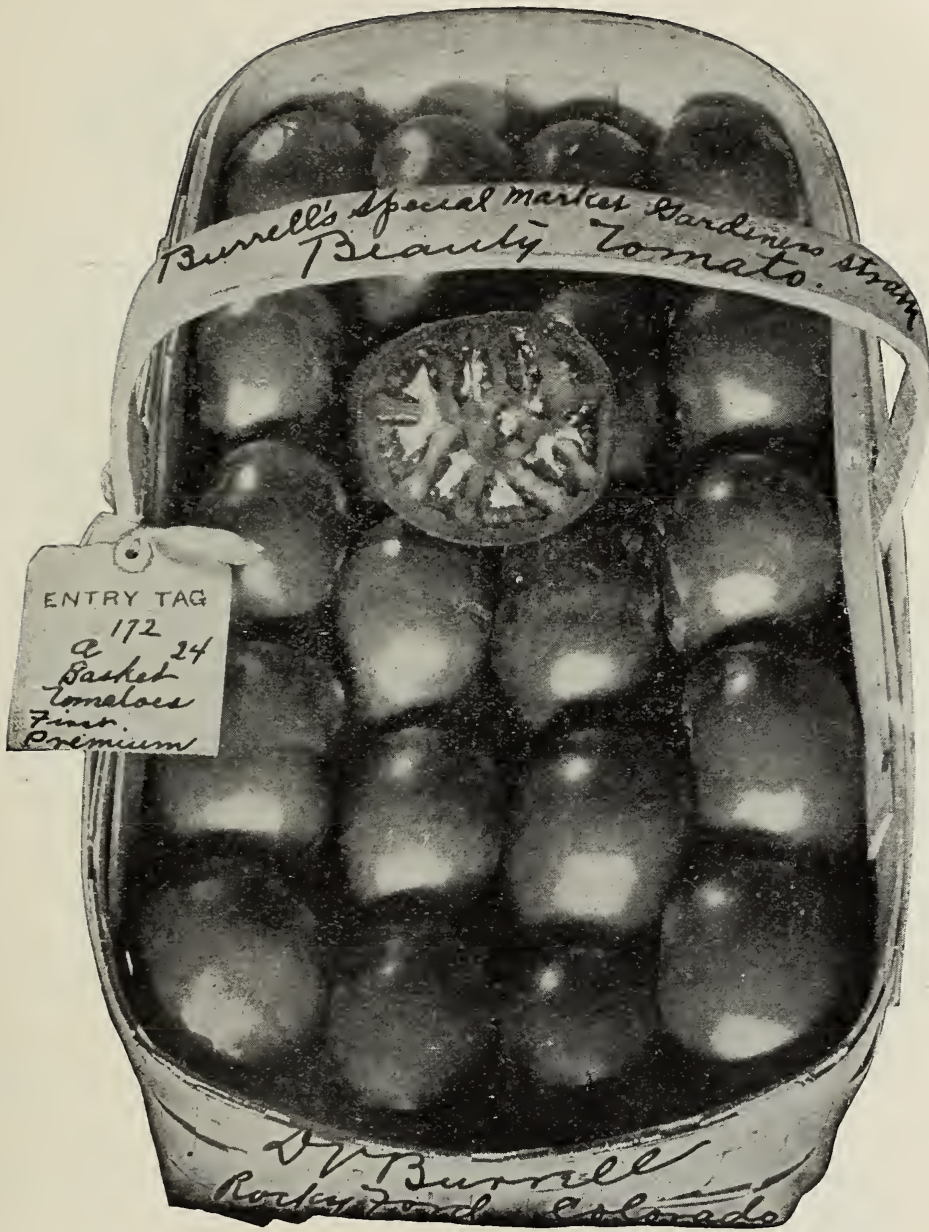

\section{Market Gardeners' Strain Beauty Tomato}

This strain has been carefully selected for a number of years until it is now far ahead of the seed of this variety usually offered. The photo above is of a basket of these tomatoes which won first premium at the Rocky Ford Falr, On the market 8 -pound baskets of these sold readily at $50 \mathrm{c}$ per basket, when 20 pound baskets of ordinary tomatoes were selling at $75 \mathrm{c}$ per basket, nearly double the price of ordinary tomatoes. It pays to plant only the best.

This strain is not offered through any other source. Those who secure a supply will be fortunate.

Remember, an ounce of seed produces 2,500 to 3,000 plants, and at the price per ounce, the cost compared with the crop is practically nothing.

No better sort for home garden or shipping; hardy, strong grower, productive, fruits large, smooth, and of excellent quality. Color a glossy crimson tinged with purple. Grows in clusters of 4 to 6 large fruits and retains its large size late in the season. The flesh is firm, skin tough, and it seldom rots or cracks after it rains. They can be picked as soon as there is a slight change in color from green, and ripen up nicely, look well and keep a long time after ripe.

Price: Pkt., 10c; 1/2 oz., 50c; oz., \$1.00; 1/4 lb., \$3.75; lb., \$14.00.

An ounce of this seed may make your crop worth $\$ 100$ more than ordinary seed. Large numbers have planted it with excellent success. 

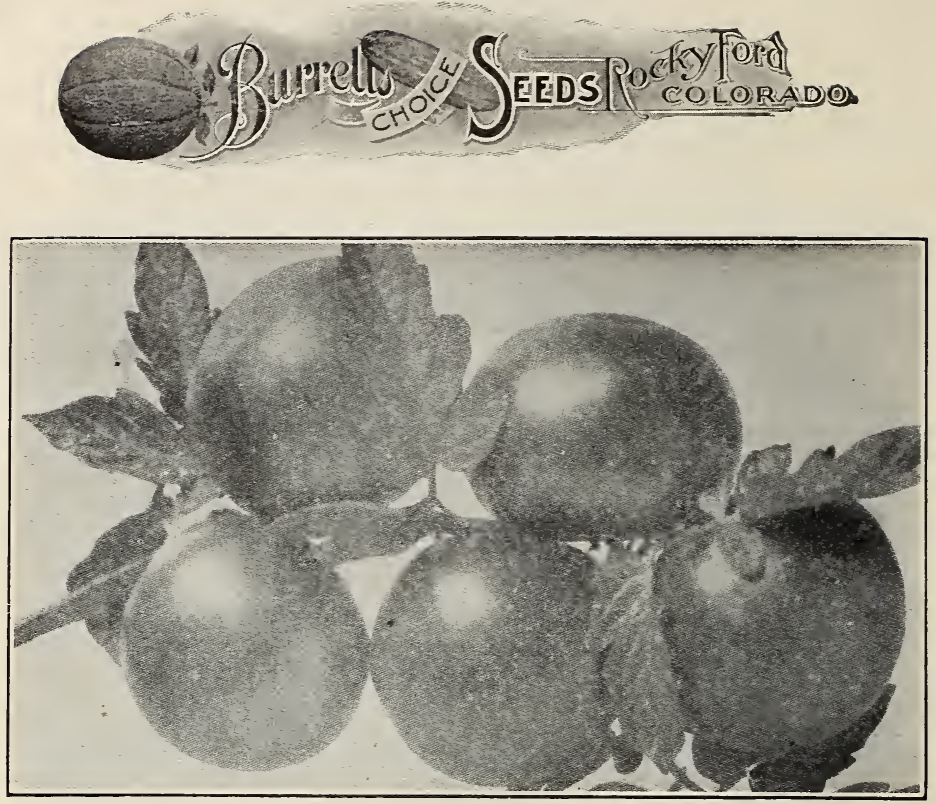

\section{Burrell's Special Selection of Chalk's Early Jewel Tomato}

Selecting the very finest specimens of this valuable variety has resulted in this special selection which I have to offer you of my own growing, and I recommend it to the most critical growers. No matter how particular your trade is, no matter how good tomatoes you have been growing, you can afford to plant liberally of this seed.

The fruits begin to ripen four or five days later than the Earliana, are large, bright red, quite solid and very smooth; they ripen without cracks or green core. The flesh is thick and solid, with comparatively few seeds.

I count on establishing as great a record for my special strains of tomato seed as for ny special cantaloupe seeds, and believe I am entitled to such a price as will pay me for taking extreme care in selection.

Pkt., 10c; $1 / 4$ oz., 30c; oz., \$1.00; 1/4 1b., \$3.75; 1b., \$7.00. Not over 1/2 lb. of this grade to one customer.

Standard Grade Chalk's Early Jewell. This is grown especially for seed for me under contract by a tomato seed specialist, but is not my own growing. Pkt., 5c; oz., 35c; $1 / 4$ lb., $\$ 1.00$; Ib., $\$ 3.75 ; 5$ lbs. and up, $\$ 3.50$ per lb.

Price of Tomato Seed. Yes, I make a good profit on tomato seed at $\$ 1.00$ per ounce, but no more than the gardener who grows select early tomatoes and sells them for $5 \mathrm{c}$ per pound, and it takes the finest of these very early tomatoes to produce this best seed. Then, by planting an ounce of this choice seed at $\$ 1.00$, you have only to sell 20 pounds of early tomatoes per acre at $5 \mathrm{c}$ per pound to pay for this seed, and a good crop may enable you to average $5 \mathrm{c}$ per pound for 2,000 to 3,000 pounds per acre, besides giving you a total yield of 12 to 20 tons per acre. It is only this: The best seed is the lowest in cost and the person making a specialty of carefully selecting the seed should get a price for it equal to what may reasonably be expected for the early fancy tomatoes on the market. 


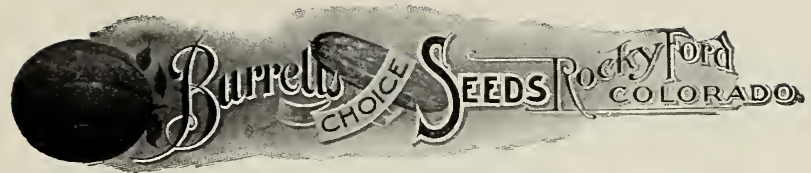

\section{Sparks' Earliana Tomato, Burrell's Special Strain}

This Extra Early, red tomato has been the source of large returns with many market to m a to growers. The plants grow rather open and are loaded with eruits. Will grow best set about $3 \frac{1}{2}$ feet apart each way and by starting the plants early in hot beds you will have tomatoes about sixty days after setting out the plants. The bright red fruits are quite un iform in shape, good marketable size and very smooth for so early a sort. The habit of growth is such that the vines do not hide the fruits, making them less liable to sun-scald, as from the first they become accustomed to the direct rays, and also allowing them to be picked at small expense.

They are borne in large clusters a $\mathbf{n}$ d the yield is heavy.

This strain is far ahead of the Standard Earliana seed. One of the most critical seedsmen of the Un I t e d States went over my field the season of 1909 . and wanted to purchase of this seed to introduce it as a novelty. He stated they were the finest

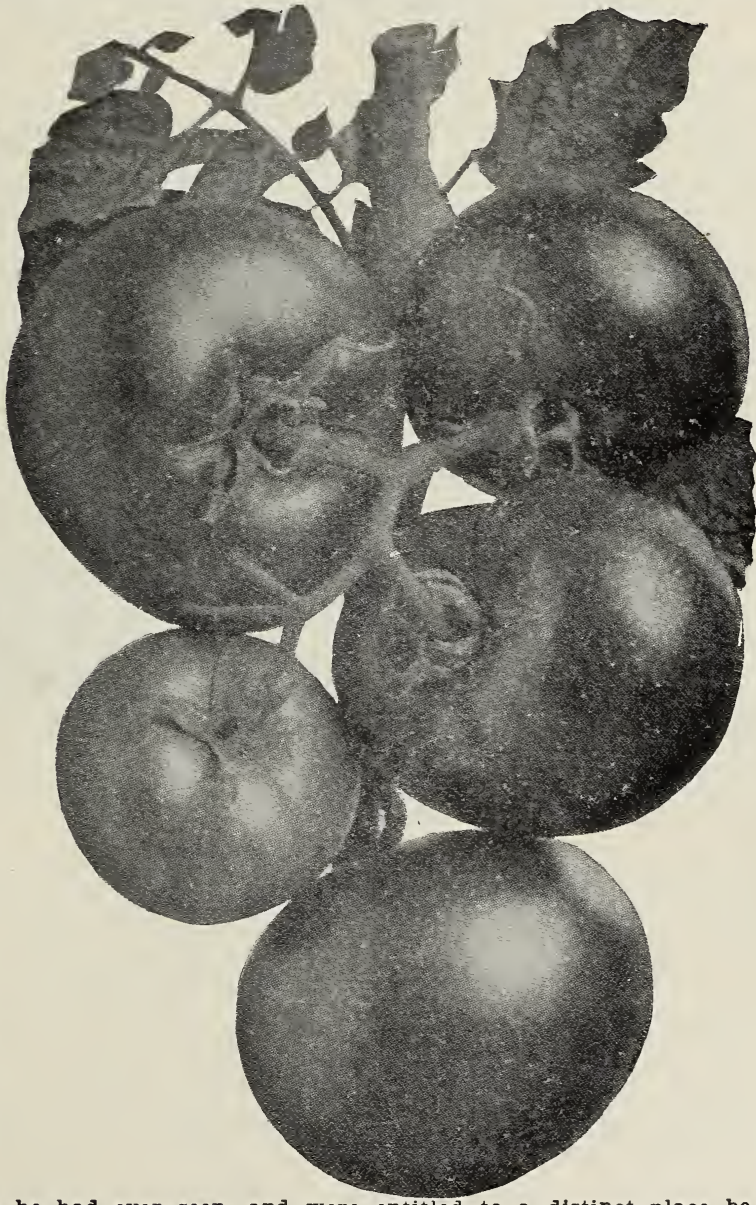
Extra Early tomatoes he had ever seen, and were entitled to a distinct place because of their superior quality.

If Extra Early Tomatoes of the finest quality will make you money, or if you live in the North where it is difficult to get the tomatoes early enough to mature the crop, this is the sort you want.

One of my Iowa customers writes: "I had ripe tomatoes two weeks earlier than any of my neighbors." That would mean a good deal to you, wouldn't it?

Price: Pkt., 10c; $1 / 4$ oz., 30c; oz., $\$ 1.00$; $1 / 4$ lb., $\$ 3.75 ; 1 / 2$ lb., $\$ 7.00$. No more than $1 / 2$ pound to one person.

Standard Sparks, Earliana Tomato. This seed is very desirable. It is grown for me by a tomato seed specialist. Price: Pkt., 5c; oz., 30c; 1/4 lb., 85c; lb., \$3.20;

5 lbs. and up, $\$ 3.00$ per $1 \mathrm{lb}$. 


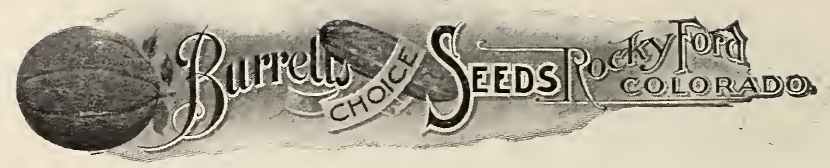

\section{The New Hummer Tomato}

THIS VALUABLE VARIETY was introduced in 1907 and sold by the originator at $1 / 2, \mathrm{c}$ per seed (20c per packet of 40 seeds.) I secured a supply of this seed from him and grew my supply of seed here under irrigation, where there is no better place to mature the best seed. From this start I selected the seed offered here. It was one of the best crops of tomatoes I have ever grown. A representative of the Kansas City Packer visited the field and stated that he "BELIEVES it the finest sort in cultivation."

The fruits are round, with practically no indentation at the stem, color bright red. Fruit solid with but few seeds set near the rind. No green core; the fruits ripen all over and clear through. The center cuts solid, bright red flesh of extra quality. Almost an extra early sort.

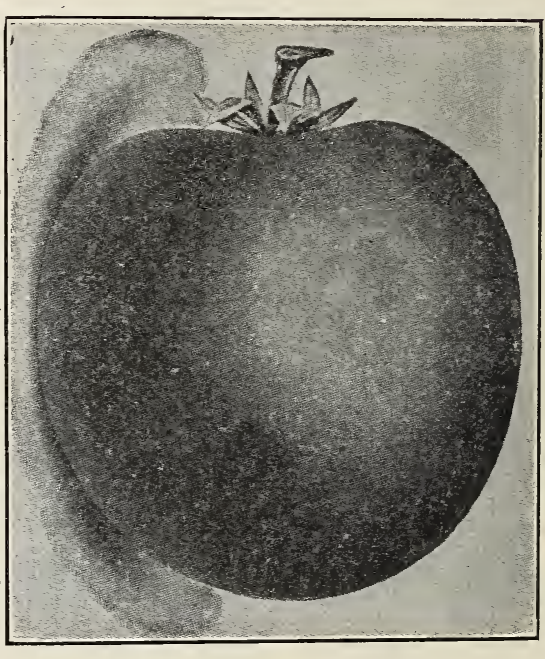

Price: Pkt., 10c; oz., 75c; 1-4 1b., \$2.75; 1b., \$10.00.

Add 8c per pound if by mail.

Above is a good illustration of both New Hummer and Livingston's Globe. The shape is the same. New Hummer is bright red. Globe purple.

\section{IIVINGSTON'S GLOBE TOMATO.}

This is one of the finest market sorts. The fruits are large, and a good marketable size is retained throughout the season; always smooth, firm fleshed and with few seeds; ripens evenly; color, a fine glossy rose, tinged with purple, and without the slightest hint of yellow at any stage of ripening. Fruit clusters spring from the main stem much closer together than in most sorts. It is a remarkably good keeper, none of the many varieties we grow surpassing it in this respect. In quality there is nothing more to be desired, being mild, pleasant and of delicate flavor, and the beautiful and attractive globe-shaped fruits will find ready sale. I sell large quantities of this seed to Southern growers.

Price: Pkt., 5c; oz., 35c; 1-4 lb., \$1.00; 1b., \$3.75. 


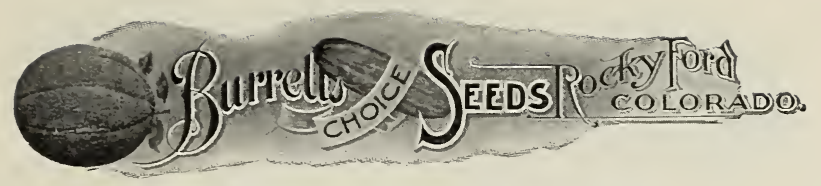

\section{TOMATOES $==$ Continued}

June Pink. This sort is among the extra earlies and the fruits are of good quality. It is grown very extensively in many fruit sections, where first in the market means so much. The fruits are medium size, pink, and of good quality. Pkt., 5c; oz., 30c; $1 / 4$ lb., $\$ 1.00$; lb., $\$ 3.50 ; 5$ lbs. and up, \$3.25 per lb.

Livingston's Early Acme. A tomato especially for early market use. Well known and generally cultivated, both for early and main crops. Plants are of strong and vigorous growth; very productive; fruits of medium size, perfect form, round, slightly depressed at the ends and very smooth (never rough); color a glossy red, with purplish tinge; ripens all over and through at the same time. Pkt., 5c; oz., 20c; $1 / 4$ lb., 60c; lb., $\$ 2.00$; 5 lbs, and up, $\$ 1.75$ per lb.

Livingston's Beauty, Standard Grade. A decided favorite for home, market or shipping; hardy, a strong grower, productive, large, always smooth, perfect shape and excellent quality. Color a very glossy crimson with a tinge of purple. Grows in clusters of 4 to 6 large fruits, retaining its large size late in the season. Ripens early and is entirely free from ribbed and elongated fruit. Flesh very firm, has a tough skin and but few seeds; seldom rots or cracks after a rain. For shipping or early market it cannot be excelled. They can be picked quite green, look well, ripen nicely and keep a week after ripe. Pkt., 5c; oz., 20c; 1/4 lb., 60c; lb., \$2.00; 5 lbs. and up, $\$ 1.75$ per lb.

The Mikado. Notwithstanding that it produces very large fruits, it is at the same time one of the very earliest grown. The tomatoes are produced in immense clusters, and are perfectly solid, generally smooth, but sometimes irregular. The color is purplish red. Foliage distinct from any other variety. Pkt., 5c; oz., 25c; $1 / 4$ lb., r0c; lb., $\$ 2.15$; 5 lbs. and up, $\$ 2.00$ per $1 b$.

Dwarf Champion. Most distinct and valuable. Dwarf, stiff habit, dark green foliage, not needing any support. It is very early and wonderfully prolific. Color same as Acme. It is perfectly round and smooth; of medium size. Pkt., 5c; oz., $25 c ; 1 / 4$ lb., 70c; lb., $\$ 2.15 ; 5$ lbs. and up, $\$ 2.00$ per lb.

New Stone. Is a well-known variety, which ripens for main crop; very large, and of bright scarlet color; very smooth, with occasionally a specimen slightly octagonal shape; ripening evenly to the stem; and as the name indicates, it is very solid and an excellent shipper. Pkt., 5c; oz., 20c; 1/4 lb., 60c; 1b., \$2.00; 5 lbs, and up, $\$ 1.75$ per $l b$.

Matchless. This new late variety is one of the best, handsomest, and heaviest yielders known. The tomatoes are large, bright red, and ripen very evenly, ylelding few seeds. They are an excellent shipping variety and also good for canning. If you are growing for market plant the Earliana for the early tomato and this for the late. Pkt., 5c; oz., 25c; 1/4 lb., 70c; lb., \$2.15; 5 lbs. and up, $\$ 2.00$ per lb.

Magnus. A distinct and new variety; purple, robust in habit, and a good main crop sort. Pkt., 5c; oz., 25c; 1/4 lb., 70c; lb., \$2.15; 5 lbs, and up, \$2.00 per lb.

Livingston's Perfection. The fruit is almost round, ripens clear up to the stem, is solid and rich in flavor. The skin is both thin and tough, making it a good shipper, while its clear, scarlet color makes it most attractive. Pkt., 5c; oz., 20c; $1 / 4$ lb., 60c; lb., $\$ 2.00 ; 5$ lbs, and up, $\$ 1.75$ per lb.

Ponderosa. This is the largest fruited tomato and of fine quality for slicing. The vines are of strong, rather open growth; fruits largely oblong in form, deep through, and generally ridged or ribbed; deep purple in color. The flesh is solid, with small seed cells, and of fine, sweet flavor. Planted in good soll, fruits frequently attain a weight of one pound and over. Rather late to ripen. Pkt., 5c; oz., 30c; $1 / 4$ lb., $\$ 1.00 ; 1 b ., \$ 3.50 ; 5$ lbs. and up, $\$ 3.25$ per $1 b$.

Honor Bright. A very heavy yielder of uniformly good fruit. The quality is excellent when ripened on the vines, and if picked when flrst beginning to show color it ripens in transit to market or when laid on shelves after frost and is of very good quality. One of the best. Pkt., 5c; oz., 25c; 1/4 lb., 70c; lb., \$2.15; 5 lbs. and up, $\$ 2.00$ per lb.

Paragon. Fruit large, dark red in color, and perfectly smooth. The flesh is solld and of excellent flavor. It ripens evenly and quickly. Much used for canning purposes. The foliage is heavy. The Paragon is sometimes described as being as smooth as an apple. It is a favorite market variety in certain sections. A fine variety and a heavy bearer. Pkt., 5c; oz., 25c; 1/4 lb., 70c; lb., \$2.15; 5 lbs. and up, $\$ 2.00$ ver lb.

Livingston's Favorite. A large, smooth, dark red variety; a good shipper and canner. Pkt., 5c; oz., 20c; 1/4 lb., 60c; lb., \$2.00; 5 lbs. and up, \$1.75 per lb.

White's Excelsior. A large pink main crop sort of considerable value. In some sections it is a favorite sort. While not an early sort it is an excellent shipper. Pkt., 5c; oz., 20c; $1 / 4$ lb., 60c; lb., $\$ 2.00 ; 5$ lbs, and up, $\$ 1.75$ per lb.

Yellow Plum. Fruit plum-shaped, deep yellow color; flesh yellow and good; esteemed for preserves. Pkt., 5c; oz., 25c; 1/4 lb., 70c; lb., \$2.15; 5 lbs, and up, $\$ 2.00$ per lb. Add 8c per pound to all tomatoes for postage if by mail. 


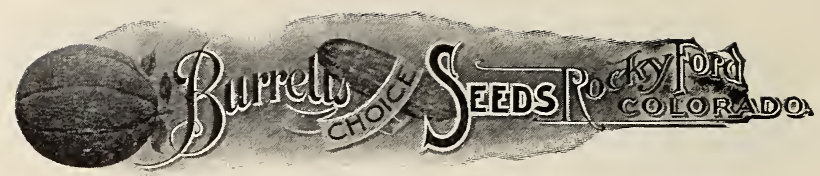

\section{Turnip==Purple Top Globe}

This is an excellent sort either for the table or stock feeding. It is a large yielder and long keeper. Price: Oz., 5c; 1/4 lb., 15; lb., 40c; 10 lbs. and up, 35c per $1 \mathrm{lb}$.

Purple Top Strap Leaved. The most widely cultivated and best known variety. Used largely for sowing broadcast among corn and potatoes. It is round and flat, white on the bottom and a reddish purple above the ground, and a very quick grower. It is a fine variety, either for the table or for stock feeding. Oz., 5c; 1/4 lb., 15c; lb., 40c; 10 lbs., \$3.50.

Early White Flat Dutch. An excellent garden variety; the best for spring sowing. Oz. 5c; $1 / 4$ lb., 15c; lb., 40c; 10 lbs., $\$ 3.50$.

Extra Early Purple Top Milan.

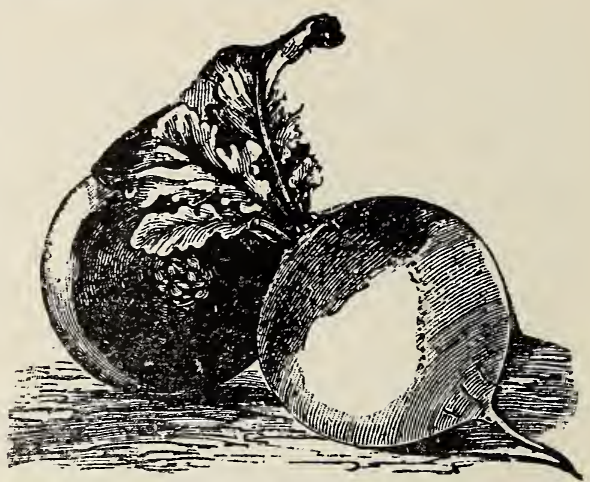

This is the earliest turnip in cultivation and a splendid variety; bulb white and flat, of medium size, with a bright purple top; one of the sweetest and finest flavored of summer sorts. Oz., 5c; 1/4 lb., 20c; lb., 50c; 10 lbs., \$4.50.

Early White Milan. One of the earliest turnips, possessing all of the good quallties of the Early Purple Top Milan. It is very smooth and entirely white. Its excellent qualities and fine appearance make it a valuable crop to grow, and it is ready for market a week earlier than any other white variety; will produce a heavy crop. It will be one of the best for market. Oz., 5c; 1/4 1b., 20c; lb., 50c; 10 lbs., \$4.50.

White Egg. Belongs to the class of quick-growing fall turnips, and for this purpose should be sown August 10th, in this latitude; a favorlte wlth market growers for winter and early spring sales. Its shape is nearly that of an egg; very fine sort. Oz., 5c; 1/4 lb., 15c; lb., 45c; 10 lbs., $\$ 3.50$. Add $8 \mathrm{c}$ per pound if by mail.

\section{Ruta-Baga}

Add $8 \mathrm{c}$ per pound if by mail.

Improved American Purple Top. Thls strain is of American origin, bred to a small top and short neck. Bulbs are of great size, yellow fleshed and purple crown, and one of the most desirable varietles now cultivated. Oz., Bc; 1/4 lb., 15c; lb., 50c; 10 lb. lots, \$4.50.

White Sweet German. Universally admitted to be the sweetest, mildest flavored and finest grained turnip for table use. Solid as a stone, and will remain in this condition until spring if properly cared for; has no equal as a turnip. Oz., Bc; $1 / 4$ lb., 15c; lb., 50c; 10 lb. lots, $\$ 4.50$.

Skirving's Yellow. A very heavy cropper. One of the best for fleld culture. Oz., 5c; $1 / 4$ lb., 15c; lb., 50c; 10 lb. lots, $\$ 4.50$.

\section{Pumps For Irrigation}

I have patents and patents pending on pumps for irrigation that cannot be excelled for the purposes for which they are adapted. They have no valves. No packing, prime themselves when started and drain when stopped.

A pump for $\$ 125.00$ F. O. B. Rocky Ford, 10 foot llft will throw enough water for 160 acres.

For $\$ 400.00,10$ foot lift will throw enough water for 640 acres. Ready for the belt and to brace in the well.

Larger or smaller sizes in proportion.

Above style of pumps is for lifts not more than fifteen feet.

My Centrifugal Syphon pump is the best pump yet offered to ralse water from wells where the water is lowered several feet to get a supply and the total lift 30 feet or less.

Write me how much water you want to lift; how high the lift; the source of the water and whether you wish to discharge the water at or above the surface and if so how many feet and I will quote on an outfit sultable for the work. Yours truly,

D. V. BÚRRELL, Rocky Ford, Coḷorąa 

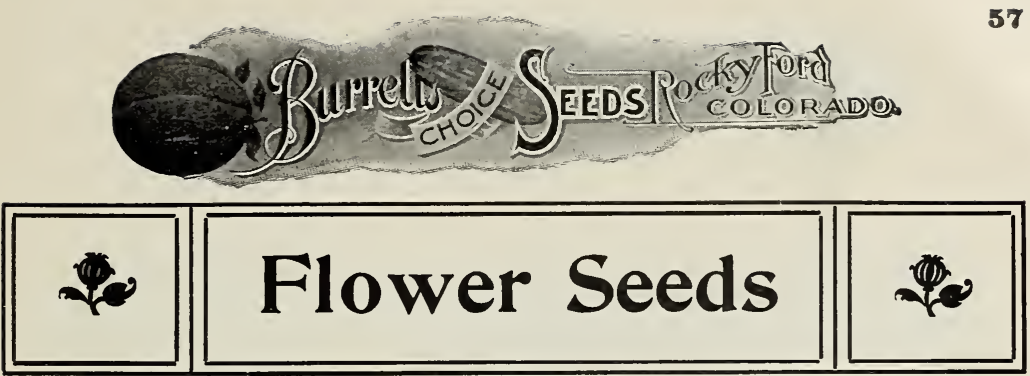

\section{ALYSSUM SWEET.}

Little Gem. A favorite little annual because of its fragrance and abundance of bloom. Grows only six inches high, yet one plant will cover a space twelve to twenty inches in diameter and be a mass of the purest white from early summer until frost. One of the finest plants for beds, borders and rockwork. Sow the seed in the open ground very early. After the first llowers fade, cut back and others will come. Pkt., 5c.

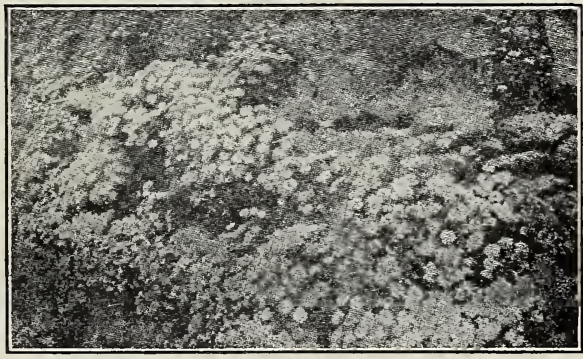

ASTER.

\section{The Queen of Autumn Annuals.}

Semple's Branching Mixed. This is a superior strain of American-grown Asters, quite different in several respects from any Aster known and by far the most satisfactory. Plants are of branching habit, vigorous growth and profuse in bloom. The flowers are borne erect on very long stiff stems, are of extraordinary size, being four inches or more in diameter, and very graceful. The twisted and curled petals give them the appearance of large Japanese Chrysanthemums. A prime favorite for cut flowers. Blooms a little later than some varieties, thereby escaping the ravages of the Aster beetle. Sow the seed in the open ground in May or start the plants in the house the last of April and transplant into the garden when they have the third or fourth leaf. Succeed best in a deep, rich soll. Pkt., 10c.

\section{ANTIRRHIUM.-Snapdragon.}

Giant Flowered Mixed. A most beautiful new sort, having all the finest colors and markings and a perpetual bloomer. The flowers are of immense size and produced in long spikes one to two feet in length. Undoubtedly one of the best cut flowers which can be readily grown from seed, while for beds or borders, they are a constant source of pleasure, being in flower all the time. They succeed best in a rather light soil in a sunny position, and although perennials, are best treated as annuals. Pkt., 10c.

\section{CANDYTUFT.}

New Empress. Among the most highly prized of summer annuals, considered indispensible for cutting. The heads of bloom are quite large and pure white. Perfectly hardy, grows easily and blooms throughout the season. Looks best in beds and masses. Sow outside where it is to bloom. Height one foot. Pkt., 10c.

\section{BALSAMS.-Lady Slipper.}

Double Camelia-Flowered Mixed. An excellent strain. The flowers are large, of fine form and as double as a Camelia; colors, varied and brilliant. The soil in which they are sown should be very rich, and if plenty of room and moisture are given, excellent results will be found in the large and abundant flowers produced. For the finest double blossoms, transplant two or three times. If sown where they are to bloom, the flowers will be semi-double to a large extent. Height twc feet. Pkt., 5c.

\section{CANARY BIRD VINE.}

A member of the Nasturtium family. A beautiful, rapid-growing, annual climber, the charming little canary colored blossoms bearing a fancied resemblance to a bird with its wings half expanded. The plant has a luxuriant rambling growth and if seeds are planted by the side of an arbor or trellis, will climb about twenty feet during the season and bloom from July until frost. Plet., Ec. 

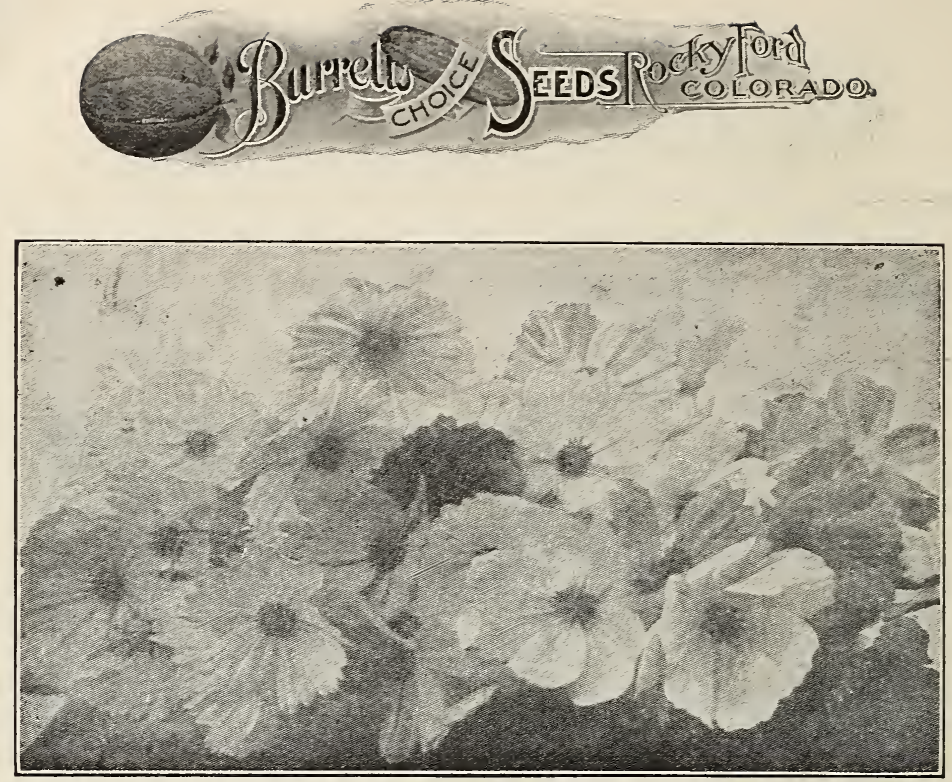

COSMOS.

Early Flowering Mixed. A favorite fall flower. This early flowering strain may be had in bloom from July to November. Plants are such strong, vigorous growers and so free with their favors, they can scarcely be spared from any garden. The foliage is fine and feathery and makes a pretty background for the beautiful long stemmed flowers of white, pink and crimson shades. Grown in rows or massed it makes a fine display; splendid for bouquets. Height four to six feet. Pkt., 5c.

\section{CANNA.}

Crozy's Dwarf Mixed. Produces plants of dwarf, luxuriant growth with immense gladiolus-like flowers of the most brilliant colors. One of the most popular of the bedding plants, also fine as single specimens. They will bloom freely the first year from seed if started about the middle of April. Before planting soak the seed in hot water twenty-four hours. When plants are up to the second leaf, transplant singly into pots. Set out in the garden after all danger of frost is past. The roots can be kept in the cellar over winter. Pkt., 10c.

\section{CENTAUREA.-Sweet Sultan.}

Centaurea Imperialis Mixed. This is without doubt the most beautiful of all the Sweet Sultans, and unsurpassed for early summer flowers. The flowers are large, very sweet scented and borne in great abundance on long, graceful stems, rendering them valuable for cutting. Their lasting quality after being cut is remarkable. Plants grow three feet high and are of the easiest culture. Sow very early in the open ground. Pkt., 10c.

\section{CYPRESS VINE.-Ipomoea Quamoclit.}

Finest Mixed. The delicate fern-like foliage and masses of white and scarlet starshaped flowers makes this one of the most beautiful climbers imaginable. Trained to trellises or allowed to run up strings or poles, it is unsurpassed for grace and beauty. Sow in the open ground only after it is thoroughly warm. The seed start more readily if soaked in warm water two hours before sowing. Grows about six feet high. Pkt., 10c.

\section{DAISY.}

Shasta. One of Luther Burbank's hybrids, the result of a cross between the common field daisy and a European sort. It is a hardy perennial bearing large, graceful flowers of the purest whiteness, averaging about four inches in diameter. The stems are twelve to eighteen inches long. Can be multiplied by division of the roots or by sowing the seed. Small plants will not bloom until late the first summer, but after once established they bloom freely for several months and more abundantly with each season. The flowers remaln fresh for two weeks or more after cutting. Pkt., 10c. 


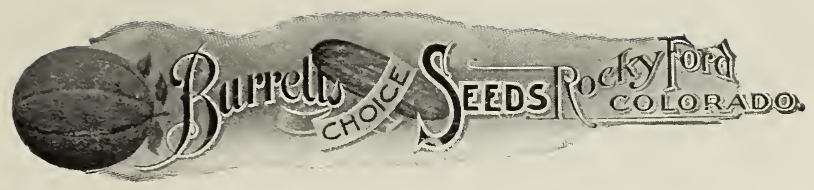

\section{DIANTHUS.}

Double Mixed. Few flowers can equal these in beauty and profusion of bloom. For garden decoration they are one of the most satisfactory annuals and as the stems are long, are equally good for cutting. The combination of colors is almost endless. Seed sown out doors as soon as possible in the spring will be a mass of bloom in a few weeks' time. The delicacy and richness of the tints combined with the delightful iragrance makes them general favorites. Pkt., 5c.

\section{DAHLIA}

Double Cactus Mixed. A distinct and elegant variety, the most popular at the present time. Unequalled for its rich and varied colors and perfection of bloom. Dahlias are easily grown from seed and bloom the first season. Seed sown in the house in March and April will produce flowering plants as soon as those grown from tubers, and no two plants will be alike in flower. They are very easy to germinate. As a cut flower the Dahlia is unsurpassed owing to its diversity of bloom and brilliant colors. Pkt., 10c.

\section{GAILLARDIA.-Blanket Flower.}

Fine Mixed. Beautiful annuals for the flower garden, producing showy plants one to two feet high which bloom continuously from early summer until November. Flowers are of large size and greatly admired for their rich blending of colors. Thrives well everywhere. Very effective grown in masses. Excellent for cutting. Pkt., 5c.

\section{GERANIUM.}

Zonale Mixed. An excellent mixture of the largest and finest varieties. Geraniums are very interesting plants to raise from seed as there is always a chance of securing something new and desirable; in fact, propagation by seed is the only way to obtain new varieties. To get into bloom the first summer, sow seeds quite early in house and transplant as soon as large enough, giving more room. Set out in the garden when the weather will permit. Seedling plants are always healthy and make a strong, luxuriant growth, blooming more freely than old plants, especially during the fall and winter. Pkt., 10c.

\section{LARKSPUR.}

Emperor, Mixed. A well-known annual of great beauty. The plants grow compactly and are covered with long, erect flower spikes in the most delicate colors; fine for cutting. As they are not easily transplanted, sow the seed where the plants are wanted to bloom, and thin out so they will stand at least ten inches apart. Height two feet. Pkt., 5c.

\section{LOBELIA.}

Finest Mixed. Charming little plants of low, compact growth, especially prized for the edgings of beds and borders. Plants grow four to six inches high and are covered with small star-like flowers of a deep rich blue and blue marked with white. Makes pretty hanging baskets. Sow outdoors where the plants are to grow. They bloom quickly from seed and continue all through the season. Pkt., 5c.

\section{MIGNONETTE.}

Giant Machet. The best of all Mignonettes. The spikes are thick and long, deeply tinged with red on creamy white and olive. Dellciously fragrant. A plentiful supply of this popular flower can be had by making sowings in April and again in July. If the plants are thinned out to six inches apart and the tops pinched off when about two inches high, stronger plants with larger spikes of bloom will be the result. It produces the largest and finest spikes during the early spring and fall months. Pkt., 10c. 


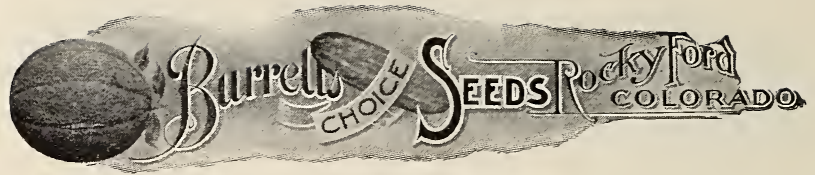

\section{ESCHSCHOLTZIA.-California Poppy.}

Glory of the West. Summer flowering annuals of low spreading growth, delicate follage and golden yellow flowers. Splendid for bedding. Very showy and free flowering. As the plants do not bear transplanting, sow where they are wanted to bloom and thin to six inches apart. Pkt., 5c.

\section{MARVEL OF PERU. Mirabilis.}

Four O'Clocks, Mixed.

Pretty, old-fashioned annuals, thriving in any common garden soll and under almost any treatment. The flowers are funnel shaped, white, red, yellow and striped, very fragrant, and have the odd habit of opening at four o'clock in the afternoon, hence their name. Sown in drills like peas, they soon make a row of plants smoothered with flowers. Give plenty of room as each plant will easily cover two feet of space. Pkt., 5c.

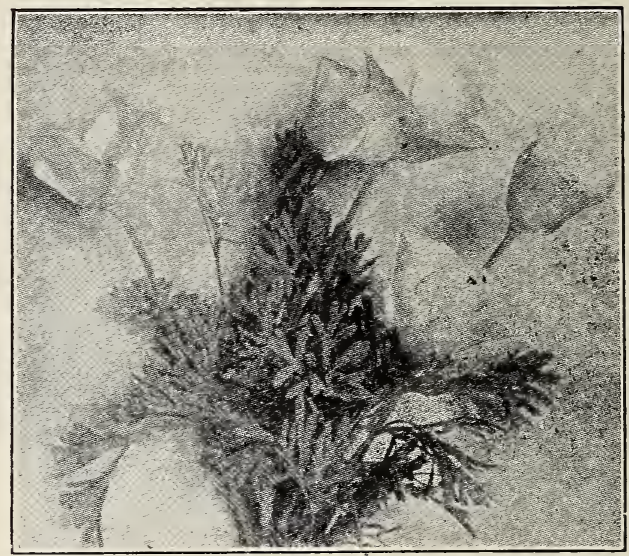

\section{NASTURTIUM.}

Finest Dwarf Mixed. The improved dwarf varieties are among the most popular flowers for bedding, massing, etc., owing to their compact growth, richness of color and profusion of bloom. They are of the easiest culture, flourishing in almost any soil and location, but put forth the largest number of flowers if planted in rather poor, rocky soil; rich soil has a tendency to make them run to leaf. When planting, scatter the seeds thinly in rows or beds and cover about one and one-half inches deep, pressing the soil down firmly. After they are well up, thin to not less than four inches apart so the plants will have plenty of room in which to grow. Keep the flowers picked so no seed pods can form and you will have continuous bloom until frost. Pkt., 5c; oz., 10c.

\section{PANSY.}

Giant Trimardeau Mixed. The largest flowering of all pansles. To succeed with pansies, only the best seed should be sown. Have the bed where it will not receive the full heat of the sun; the east and north side of the house is generally a good location. Remember the soil must be loose and rich, and the flowers picked constantly as the more they are picked the more they will come. Seed sown in the house or hot bed between January and April or in the open ground as soon as the soil can be worked in the spring will give flowers all summer and fall. For early spring blooming and for the largest and finest flowers, sow between July and September and protect during the winter. Pkt., 10c.

\section{POPPY.}

Paeony Flowered, Mixed. Large double, showy flowers almost equal to Paeonies. Poppies are of quick growth and produce a wealth of the most gorgeous blooms. Seed should be sown early where they are to bloom and covered lightly; thin to six inches apart. Do well in any good garden soll. Pkt., 5c. 


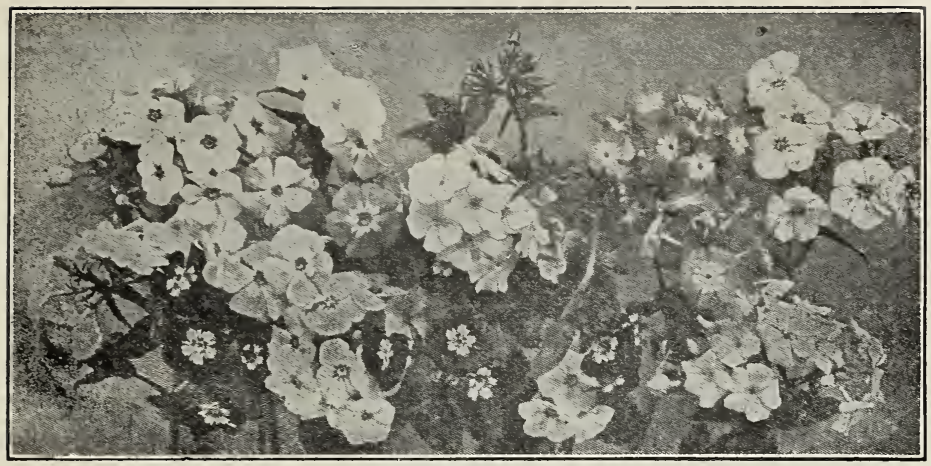

\section{PHLOX.}

Drummondii Grandiflora. Flowers nearly twice as large as the ordinary Phlox Drummondii while the colors are richer and brighter. For a splendid mass of color and constant display Phlox is not excelled by any other annual. It has every desirable quality for this purpose; and for beds, borders and massing it is unsurpassed. The colors range from purest white to deepest crimson. Sown outside they bloom very soon after planting and until frost. For early bloom, seed may be sown inside and transplanted. In either case they make a most showy bed of brilliant flowers the whole summer. Height one to one and one-half feet. Pkt., 5c.

Double Mixed. There are scarcely any flowers in cultivation which make such a dazzling display of beauty as a bed of many-hued portulaccas. Blooms from July until frost. Very desirable for beds, borders, rock work and ribbon beds and especially adapted for sunny situations and light sandy soils. Sow in the garden as soon as it becomes warm and after the plants appear, withhold water. Stands any amount of hot, dry weather and can be easily transplanted when in full bloom. The flowers of the double variety resemble small roses. More than half of the plants will produce double flowers; the rest can be pulled out as soon as they bloom. Pkt., 10c.

\section{PETUNIA.}

Giants of California. The largest flowering and richest colored variety in cultivation. Single flowers often measure over five inches in diameter, are exquisitely ruffled and fringed on the edges and beautifully veined in the deep throat. Their great variety of colors, markings and veinings distinguishes them from all others. Petunias succeed finely anywhere and give a constant supply of the richest and most brilliant flowers from early summer until frost. The seed is best started in the house and the young plants transplanted into the garden, but if the soil is made very fine, seed can be sown in open ground and covered lightly. Pkt., 10c.

arge Flowering Double Mixed. This is one of our best bouquet flowers. The rich velvety blossoms are borne on long, graceful stems well above the foliage and after being cut keep in perfect condition for the greater part of a week. They are almost as durable as everlastings. The range of color is most remarkable, shading from pure white to rich pink, crimson to deep red, and from lilac to almost black. They are of the easiest culture. Plants grow two and one-half feet high and come into bloom early in July, continuing without interruption until the late frosts of autumn. Make most effective beds and borders, and where many cut flowers are wanted are almost indispensible. Pkt., 5c.

\section{VERBENA.}

Mammoth Mixed. The verbena of today is one of the most satisfactory plants that anyone can cultivate and a bed of the bright, waving heads of bloom will make a picture that once seen is rarely forgotten. Single flowers of this Mammoth strain are of unusual size, while the clusters of bloom are magnificent and the range of color more vivid than in any other mixture. They are also deliclously fragrant. Although perennials, they bloom perfectly well the first season from seed and are more vigorous than if started from cuttings. For early spring bloom, sow quite early in boxes in the house and transplant to the open ground when it is warm. Seed sown in May will bloom in August. Pkt., 5c.

\section{VIOLETS.}

Single Blue. The violet should not be wanting in any garden on account of its fragrance and early appearance. A single flower will perfume a whole room. They are well adapted for borders or rock-work and after once started commence putting forth their beautiful single blossoms in April and continue through May. Succeeds best in a shady, sheltered place. The violet is an emblem of futheulness. Hardy perennial; four inches high. Pkt., 5c. 


\section{Sweet Peas}

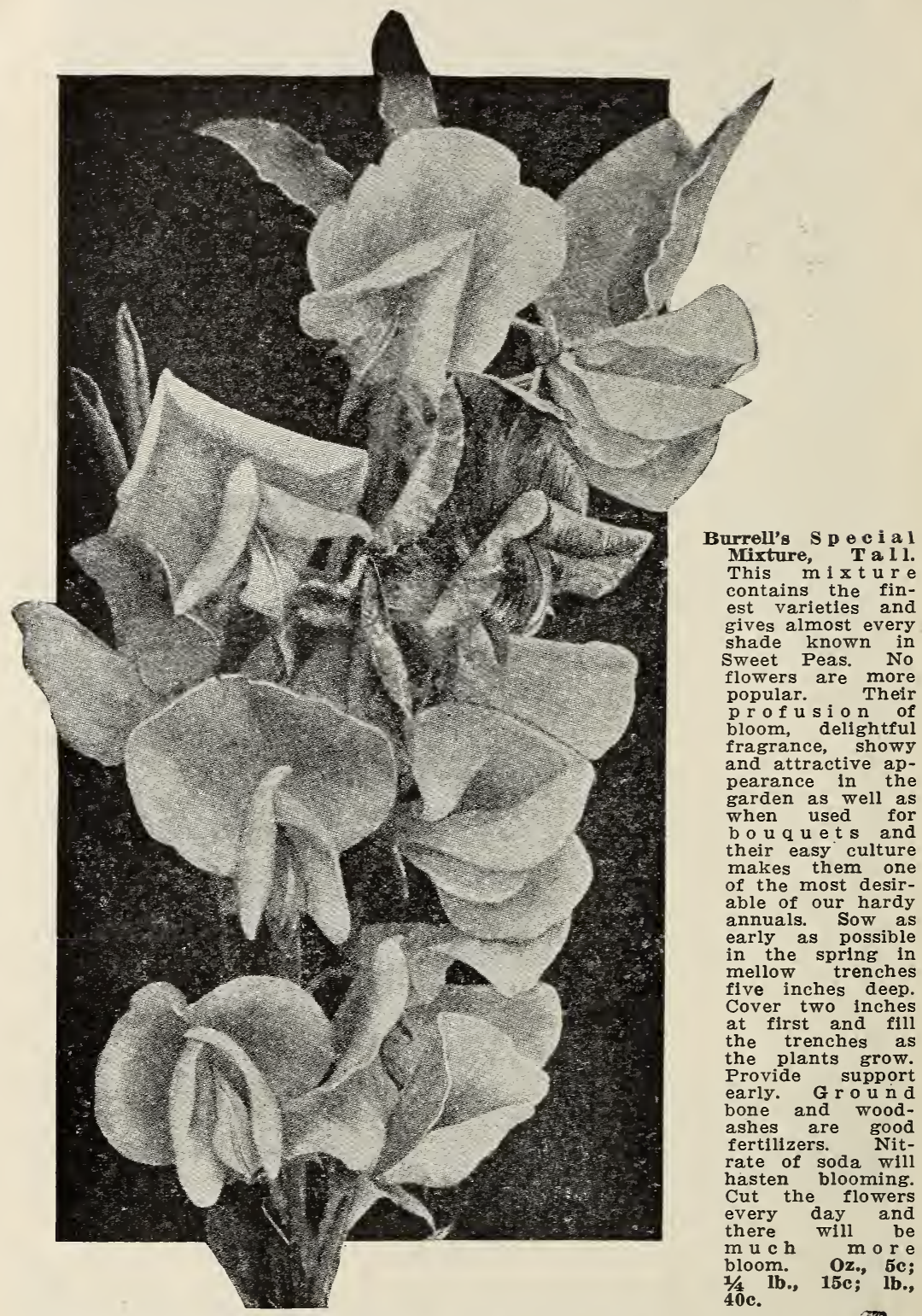

SPECIAL OFFER-One-half pound of these Sweet Peas will be included with each one dollar order for flower seeds. 


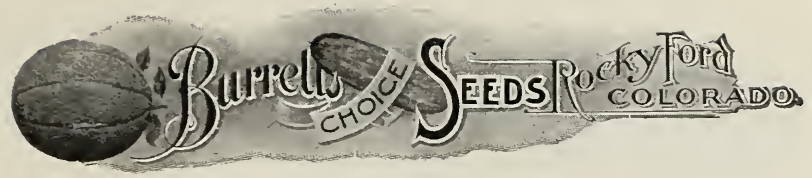

SWEET PEAS.

Cupid or Dwarf Mixed. A new and entirely distinct race. The vines are of low, compact, spreading form, seldom more than six inches in height. Flowers fully equal in size to the tall growing varieties, but placed closer together. This mixture contains a wide assortment of shades ranging from pure white through light pink to deep red, and from lavender to deep purple with several attractive striped varieties. By reason of their close, dense growth, the Cupids succeed better in a light dry soil. They are fine border plants. Pkt., 5c; oz., 10c; 1/4 lb., 20 ; lb., 60c.

\section{SALVIA.-Scarlet Sage.}

Very ornamental plants, flowering in spikes, and continues to bloom in open ground until frost, when the plants can be removed to the greenhouse and will continue to bloom a long time. Plants may be started in a hot-bed and transplanted to light, rich soil, about one foot apart. Tender perennials. Pkt., 10c.

\section{ZINNIA.-Youth and Old Age.}

Giant Mammoth Mixed. A new class of Zinnias, giant in size. No flowers are more easily grown from seed sown in the open ground and few bloom more continuously throughout the summer. The plants grow about three feet high and bear perfectly double flowers of the richest and most varied colors and shades, measuring nearly five inches across. Particularly valuable for groups. Pkt., 5c.

\section{General List of Flower Seeds}

Abutilon. Large, bell-shaped flowers, richly veined; tender perennial. Finest varieties mixed. Pkt., 5c.

Ageratum. Used largely for bedding and borders; mixed colors. Pkt., 5c.

Alyssum. Little Gem. See page 57.

Amaranthus Tricolor. (Joseph's Coat.) Showy annual follage plant; leaves red, yellow and green. Height 3 feet. Pkt., 5c.

Anemone. (Wind Flower.) Beautiful spring flowering plants; many rich colors. Hardy perennial. Pkt., 5c.

Antirrhinum. (Snapdragon.) G i a $\mathrm{n} \mathrm{t}$ Flowering Mixed. See page 57.

Aquilegia. (Columbine.) A hardy perennial. Single Mixed. Pkt., 5c.

Asperula Azurea Setosa. Light blue or lavender flowers. Hardy annual. Height 9 inches. Pkt., 5c.

Aster. Semple's Branchrng, Mixed. See page 57.

Semple's Pure White. Pkt., 10c.

Semple's Light Blue. Pkt., 10c.

Semple's Shell Pink. Pkt., 10c.

Asparagus Fern Sprengeri. Fine plant for pot culture or hanging baskets. Pkt., 10c.

Bachelor's Button. A showy annual; great variety of colors. Pkt., 5c.

Balloon Vine. (Love in a Puff.) Rapid growing annual climber; white flowers, followed by balloon-like seed pods. Pkt., 5c.

Balsam. Double Camelia Flowered. See page 57.
Calliopsis. Showy garden annual; golden yellow flowers; choicest mixture. Pkt., 5c.

Canary Bird Vine. See page 57.

Candytuft. See page 57 .

Canna. Crozy's Dwarf. See page 58 .

Carnation. Choice Double Mixed. Produces many double flowers of all shades and colors. Pkt., 10c.

Centaurea. Imperialis Mixed. See page 58.

Celosia Cristata. (Cockscomb.) Tall sorts, mixed. Pkt., 5c.

Clematis. Paniculata. One of the finest hardy climbers. Fragrant white flowers. Pkt., 5c.

Coix Lachryma. (Job's Tears.) Curious ornamental grass from East India, with broad corn-like leaves, and seeds of a light slate color, wonderfully lustrous. Valuable for winter bouquets. Pkt., 5c.

Convolvulous. (Morning Glory.) Major. All colors mixed. Pkt., 5c.

Cosmos. Early Flowering, Mixed. See page 58.

Chrysanthemum. Annual Varieties Mixed. Pkt., 5c.

Perennial Varieties Mixed. Pkt., 10c.

Cuphea. (Cigar, or Firecracker Plant.) A pretty bedding plant. Flowers resemble a lighted cigar. Mixed. Pkt., 5c.

Cypress Vine. See page 58.

Dahlia. Double Cactus Mixed. See page 59. 


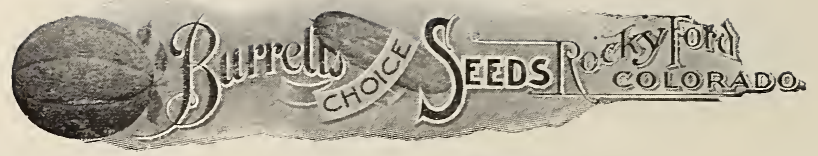

\section{Flower Seeds $==$ Continued}

Daisy. Shasta. See page 58.

Bellis, or Double Daisy. Perennials, will bloom the same season if sown early. Pkt., 10c.

Dianthus. Double Mixed. See page 59. Snow Queen. Beautiful snow white variety of pinks. Pkt., 10c.

Digitalis. (Foxglore.) Flowers borne in tall spikes, bell or thimble shaped. All colors. Pkt. Gc.

Dolichos. (Hyacinth Bean.) Desirable climbing plant. Mixed colors. Pkt., 5c.

Eschscholtzia. (California Poppies.) See See page 60 .

Fuchsia. Double, Finest Mixed. Easily grown from seed. Pkt., 25c.

Gaillardia. See page 59.

Geranium. Zonale Mixed. See page 59.

Gilia. Mixed colors. Hardy annual. Among the earliest to flower and will keep long in water. Flowers grow in clusters. Pkt., 5c.

Gypsophila. (Baby's Breath or Angel's Breath.) Elegant. Charming for mixing with bouquets. Star shaped white flowers. Pkt., Бc.

Heliotrope. Fine Mixed. Very fragrant, excellent for bedding or indoor cultivation. Pkt., 5c.

Hollyhock. Double Mixed, Best. The flowers are as double as a rose and of many shades of color. Once started they keep coming year after year. Pkt., 10c.

Double Mixed, Good. Pkt., 5c.

Ipomoea. (Moon Flowers, Brazilian Morning Glories.) New Hybrid climbers of very rapid growth, with many beautiful and varied flowers. Pkt., 10c.

Lantana. Finest Mixed.. Tender perennial. Excellent for bedding or pot culture. Pkt., 5c.

Larkspur. Emperor Mixed. See page 59.

Lobelia. Finest Mixed. See page 59.

Marigold. African Mixed.. Of easy cultivation, producing an elegant display of perfectly double orange, yellow and brown flowers. Height 3 feet. Pkt., 5c.

Marvel of Peru. Four O'Clocks Mixed. See page 60 .

Matricaria. (Feverfew.) Capensis, double white. Will bloom first season from seed. Perennial. Pkt., 5c.

Mignonette. Giant Machet. See page 59.

Myosotis. (Forget-Me-Not.) Palustris. Neat and beautifur ittle plants, with pretty star-like flowers. Succeed best in a moist, shady place. Bloom first year if sown early. Pkt., 5c.

Nasturtium. Finest Dwarf Mixed. See page 60 .

Tall Varieties Mixed. Sultable for trellis. Pkt., 5c; oz., 10c.

Nigella. (Love in a Mist.) Small blue flowers, finely cut follage. Hardy annual. Pkt., 5c.

Oxalis. Mixed. Very attractive plants, with richly colored flowers, suitable for rock work and rustic baskets. Half-hardy perennial. Height 6 inches. Pkt., 10c.

Pansy. Giant Trimardeau Mixed. See page 60 .

Good Mixed. Pkt., 5c.

Giant Golden Queen. Pkt., 10c. Giant Royal Purple. Pkt., 10c. Giant Violet Blue. Pkt., 10c.

Petunia. Giants of California. See page 61.

Phlox. Drummondii Grandiflora. See page 61.

Poppy, Paeony Flowered. See page 60 . Double Carnation Flowered Mixed. Pkt., 5c.

Portulacca. Double Mixed. See page 61.

Single Mixed. Pkt., 5c.

Primula Veris. (Cowslip.) The wellknown English Cowslip, flowering early in spring. Pkt., 5c.

Pyrethrum. (Golden Feather.) Very useful and universally admired, ornamental foliage bedding plants. Golden-yellow foliage and white flowers. Pkt., 5c.

Ricinus. (Castor Oll Plant.) Stately, strong growing plants with very ornamental follage. Annuals of very quick growth. Pkt., 5c.

Rhodanthe. Mixed. One of the best, everlasting flowers and a charming annual. Pkt., 5c.

Salpiglossis. Mixed Varieties. (Velvet Flower or Pointed Tube Tongue.) Showy bedding or border plants, with richly colored, erect funnel-shaped flowers. Pkt., 5c.

Salvia. (Scarlet Sage.) See page 63.

Scabiosa. (Mourning Bride.) See page 61.

Schzanthus. (Butterfly Flower). Mixed Colors. Excellent free-flowering plant for garden or greenhouse, bearing peculiarly shaped and oddly marked flowers. Hardy annual. Plet., 5c.

Silene. (Catchfly.) Mixed colors. Very pretty for low beds or edgings. Flowers white, pink and red. Annual. Pkt., 5c.

Sengitive Plant. Leaves close if touched. Pkt., Bc. 


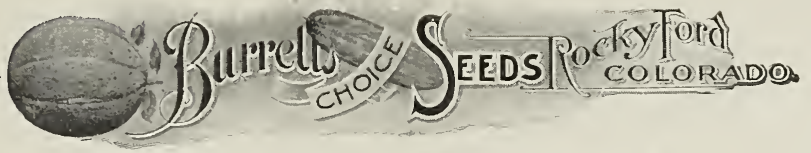

\section{Flower Seeds $==$ Continued}

Smilax. Charming tender perennial climber for greenhouse or window gardens. Tery graceful. Excellent for decoration. Pkt., 10c.

Stocks. (Gillyflower.) Good mixed. Unsurpassed in brilliancy of color and general effect. Fine lor bedding, borders, massing and pot culture. Pkt., 10c.

Stokesia Cyanea. (Cornflower Aster.) Beautiful blue flowers borne freely until frosț. Pkt., 10c.

Sweet Peas. Burrell's Special Mixture. See page 6 ?.

Eckford's Mixed. This mixture contains all of the famous Eckford varieties in an excellent mixture. Oz., 5c; 1/4 lb., 15e; lb., 40 .

Bush Sweet Peas. A splendid mixture, entirely distinct. The plants are erect, 15 to 18 inches in height, branching freely, requiring no support. The flowers are of fine form and beautiful coloring, but not quite so large as the Tall sweet Peas. Pkt., 5c; oz., 10c; 1/4 lb., 25c; lb., "75c.

Cupid Sweet Peas, Mixed. See page 6 sิ.

Prices of the following named Sweet Peas: Oz., 5c; $1 / 4$ lb., 15c; lb., 40c.

Blanche Burpee. Large, pure white of graceful and open form.

Mrs. Eckford. A beautiful shade of light primrose yellow.

Blushing Beauty. Light pink, attractive.

Lovely. A most beautiful shade of shell pink.
California. Very light pink.

Mrs. Dugdale. Light carmine rose; very large.

Her Majesty. Large, finely hooded flowers of beautiful soft rose, deep and glowing.

Salopian. A grand scarlet.

Venus. A lovely shade of salmon buff.

Blanche Ferry. Standards rose-pink; wings white, tinted rose.

Black Knight. Deep maroon, veined Łlack.

Aurora. Creamy white, striped orange salmon.

Admiration. A delicate shade of rosy lavender.

Captivation. Claret magenta wings heliotrope; a distinct shade.

Countess Cadogan. Color effect is that of a bright blue.

Sweet William. Double Mixed. Hardy perennial. Flowers are produced in very large heads in many brilliant and rich colors. Pkt., 5c. Single Mixed. Pkt., 5c.

Thunbergia. (Climbing Black-eyed Susan.) Mixed. A trailing or climbing plant with flowers of various shades of yellow and white, having a dark center or eye. Plkt., 10c.

Verbena. Mammoth Mixed. See page 61.

Violets. Single Blue. See page 61 .

Zinna. Giant Mammoth Mixed. See page 63 .

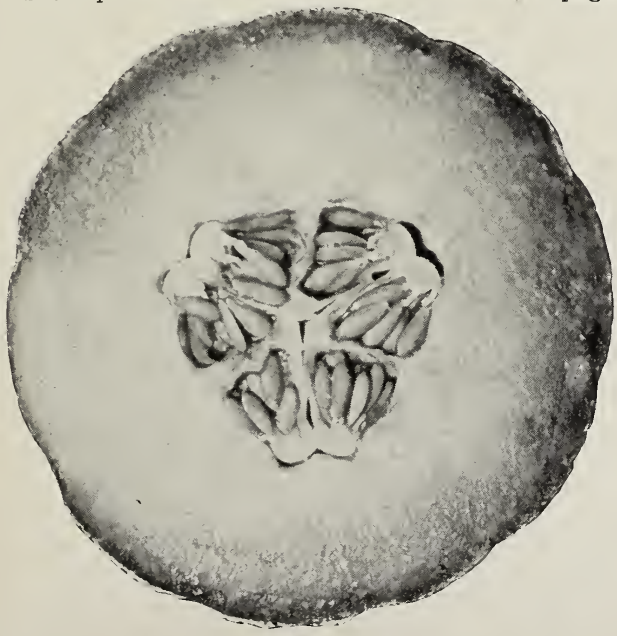

\section{Burrell's Select Rust $=$ Resistant Rocky Ford Cantaloupe}

Every melon grower should plant this variety.

Note the very deep meat and small seed cavity.

If it is only one, make this the one. 
P. 0 .

State

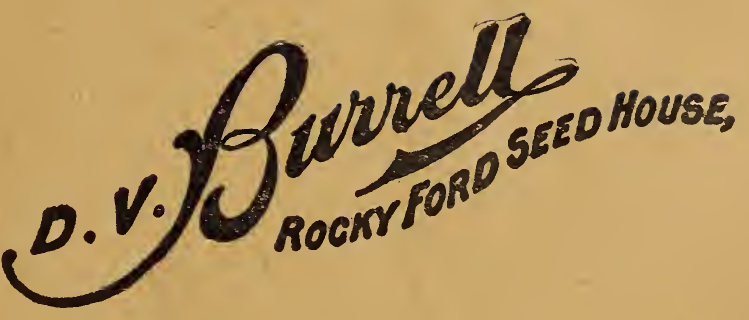

High Grade Seeds.

ROCKY FORD, COLO. 


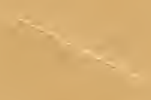

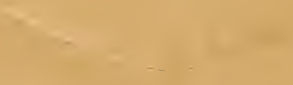

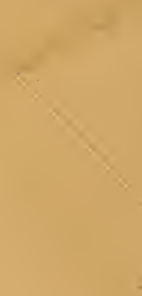

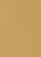




\section{Special Seeds for 1911}

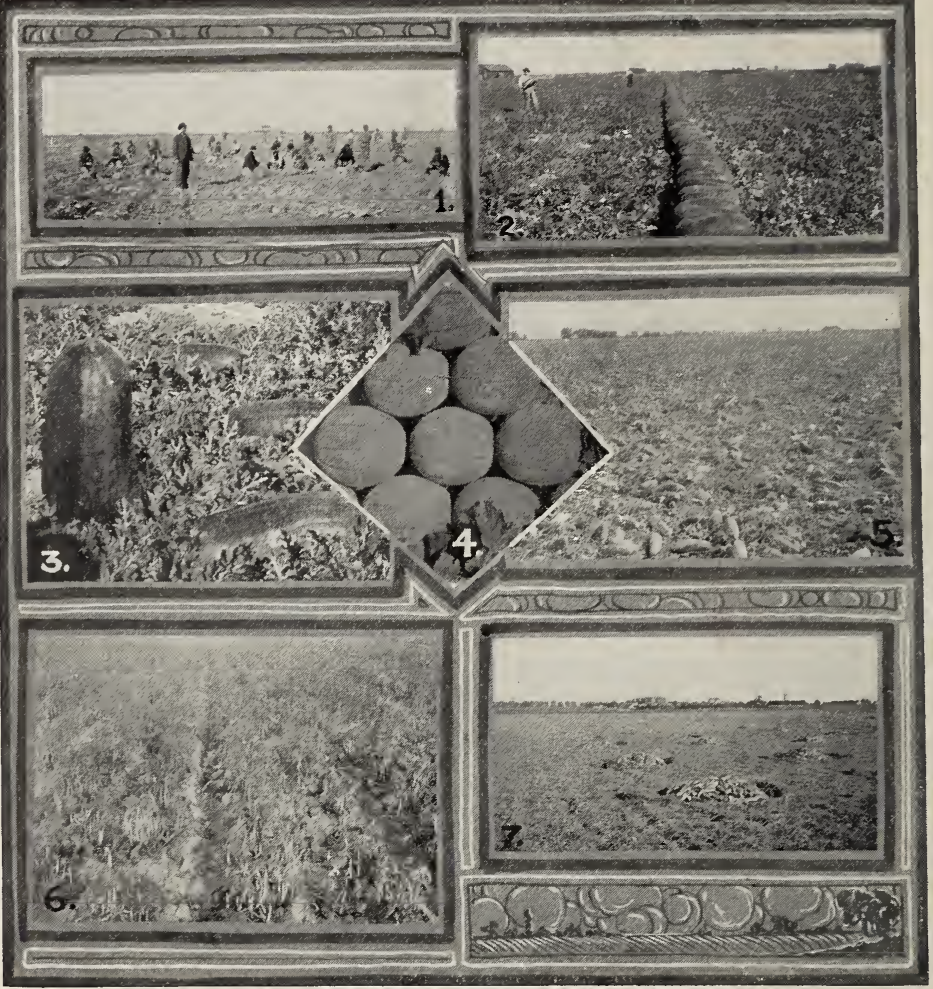

1. Seeding Squashes, Burrell's Seed Farms.

2. One of My Fields of Burrell's Improved Kleckley sweet Watermelons.

3. Same as Above, Showing Some 40-Pounders Where They Grew.

4. Burrell's Thoroughbred Rocky Ford Cantaloupes.

5. Burrell's New Klondike Cucumber. (A Good Crop.)

6. A Field of Burrell's Spot-Free Wardwell's Kidney Wax Beans.

7. A Good Field of Burrell's Select Davis' Perfect Cucumber.

D. V. BURRELL,

Rocky Ford, Colorado.

Quality First and Then as Low Prices as I Can Afford. 